\title{
COMUNIDADES DE FUNGOS MICORRÍZICOS ARBUSCULARES ASSOCIADAS À PUPUNHA E AO CUPUAÇU CULTIVADOS EM SISTEMA AGROFLORESTAL E EM MONOCULTIVO NA AMAZÔNIA CENTRAL
}

\author{
José Pereira da Silva JúNIOR
}

Tese apresentada à Escola Superior de Agricultura "Luiz de Queiroz", Universidade de São Paulo, para obtenção do título de Doutor em Agronomia, Área de Concentração: Solos e Nutrição de Plantas.

P I R A C I C A B A

Estado de São Paulo - Brasil

Dezembro - 2004 


\title{
COMUNIDADES DE FUNGOS MICORRÍZICOS ARBUSCULARES ASSOCIADAS À PUPUNHA E AO CUPUAÇU CULTIVADOS EM SISTEMA AGROFLORESTAL E EM MONOCULTIVO NA AMAZÔNIA CENTRAL
}

\author{
José Pereira da Silva JúNIOR
}

Engenheiro Agrônomo

Orientadora: Prof ${ }^{\mathrm{a}}$. Dra. ELKE JURANDY BRAN NOGUEIRA CARDOSO

Tese apresentada à Escola Superior de Agricultura "Luiz de Queiroz", Universidade de São Paulo, para obtenção do título de Doutor em Agronomia, Área de Concentração: Solos e Nutrição de Plantas.

P IR A C I C A B A

Estado de São Paulo - Brasil

Dezembro - 2004 


\section{Dados Internacionais de Catalogação na Publicação (CIP) DIVISÃO DE BIBLIOTECA E DOCUMENTAÇÃO - ESALQ/USP}

Silva Júnior, José Pereira

Comunidades de fungos micorrízicos arbusculares associadas à pupunha e ao cupuaçu cultivados em sistema agroflorestal e em monocultivo na Amazônia Central I José Pereira Silva Júnior.-- Piracicaba, 2004.

$95 \mathrm{p}$.

Tese (Doutorado) - - Escola Superior de Agricultura Luiz de Queiroz, 2005.

Bibliografia.

1. Amazônia Central 2. Biodiversidade 3. Cupuaçu 4. Fungos Micorrízicos 5. Pupunha 6. Simbiose 7. Sistemas Agroflorestais I. Título

CDD 634.6 
"Como sei pouco, e sou pouco, faço o pouco que me cabe me dando inteiro, sabendo que não vou ver o homem que eu quero ser.

Já sofri o suficiente para não enganar a ninguém: principalmente aos que sofrem na própria vida, a garra da opressão, e nem sabem.

Não, não tenho o sol escondido no meu bolso de palavras. ..." 
Aos meus pais, José e Maria Nazareth, pelo amor incondicional e exemplo de vida,

Ao Amigo Godoy,

pelo incentivo a trilhar os caminhos que

aqui me trouxeram,

\begin{abstract}
À Lucila, pelo amor, companheirismo e compreensão, ao longo dessa e de outras jornadas,
\end{abstract}




\section{AGRADECIMENTOS}

À Embrapa Amazônia Ocidental, pelo estímulo e liberação para realização deste curso.

À ESALQ e ao Programa de Pós Graduação em Solos e Nutrição de Plantas, pela oportunidade e acolhimento para concretização deste projeto de vida.

À FAPESP, pelo auxilio financeiro para o desenvolvimento desta pesquisa.

À Professora Titular do Departamento de Solos e Nutrição de Plantas Elke Jurandy Bran Nogueira Cardoso, pela confiança, incentivo, dedicação e inestimável orientação dispensada.

À Professora Sandra Maria Gomes da Costa, do Centro de Ciências Biológicas da Universidade Estadual de Maringá, pelo treinamento em taxonomia de fungos micorrízicos e pela identificação dos mesmos.

Ao Professor Márcio Rodrigues Lambais, pelas discussões, contribuições e disponibilidade do Laboratório de Microbiologia Molecular para os trabalhos referentes à Biologia Molecular.

À Professora Siu Mui Tsai do Centro de Energia Nuclear da USP, por colocar a disposição o Laboratório de Biologia Celular e Molecular para realização da atividade de sequenciamento.

Aos Técnicos do Laboratório de Microbiologia do Solo do Departamento de Solos e Nutrição de Plantas - ESALQ/USP, Denise de Lourdes Mescoloti Colombo e Luis Fernando Baldesin, pela amizade e apoio imprescindível em todas as atividades realizadas. 
Aos colegas dos Laboratórios de Microbiologia do Solo e Microbiologia Molecular do Departamento de Solos e Nutrição de Plantas pelo auxílio no desenvolvimento do trabalho, em especial a Daniele Takahashi e Ricardo Bull.

Aos colegas da Embrapa Amazônia Ocidental, principalmente aos pesquisadores Jeferson Luis Vasconcelos de Macedo e Gladys de Sousa pela colaboração e apoio, e ao auxiliar de pesquisa Raimundo César pela auxilio fundamental nas atividades de coletas de campo.

A todos os colegas do Programa de Pós Graduação em Solos e Nutrição de Plantas e de outros Programas da ESALQ/USP, pela amizade, convivência diária e discussões científicas durante o período do curso, bem como pelos momentos de alegria e relaxamento. 


\section{SUMÁRIO}

Página

LISTA DE FIGURAS ...................................................................... ix

LISTA DE TABELAS …....................................................................

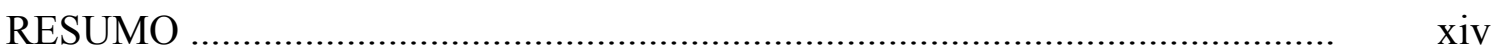

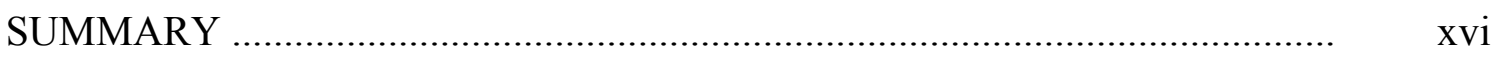

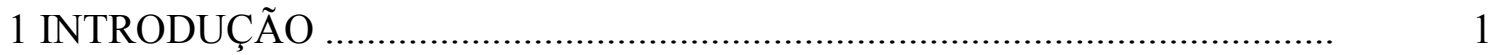

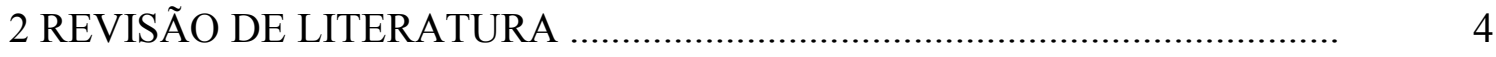

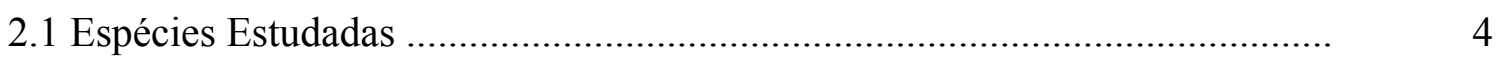

2.1.1 O Cupuaçu (Theobroma grandiflorum Willd ex Spring Schum) ................ 4

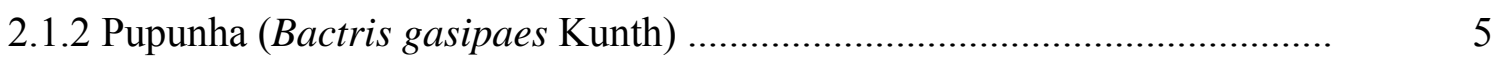

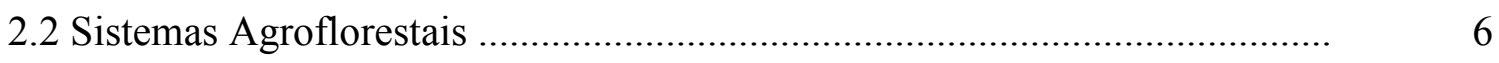

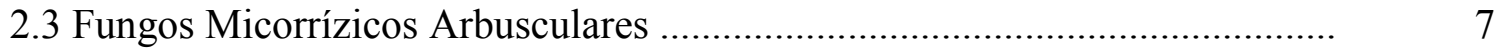

2.4 Dinâmica de Comunidades de Fungos MA em Agroecossistemas ............... 8

2.5 Técnicas Moleculares no Estudo de Comunidades de Fungos MA ............... 11

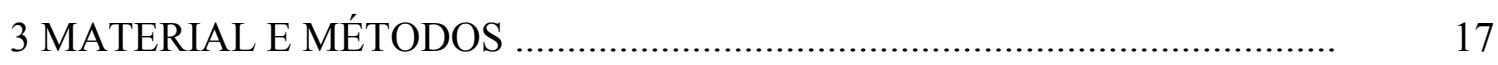

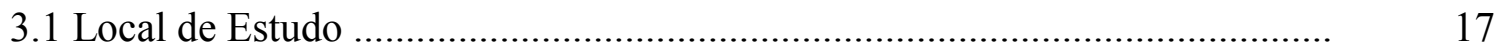





3.3.1 Levantamento de Espécies dos Fungos MA …......................................... 21

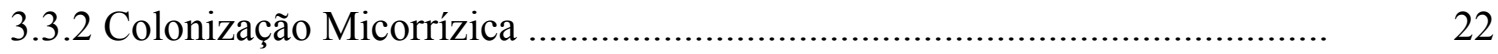

3.3.3 Caracterização Química do Solo ........................................................... 22

3.4 Parâmetros da Estrutura das Comunidades de Fungos MA …....................... 23

3.5 Freqüência Relativa de Ocorrência das Espécies de Fungos MA .................. 23 
3.6 Avaliação da Diversidade de Fungos MA em Raízes de Pupunha Através de Mini Biblioteca de Amplicons de Região do rDNA 18S ............................ 24

3.6.1 Extração de DNA Total das Raízes ............................................................ 24

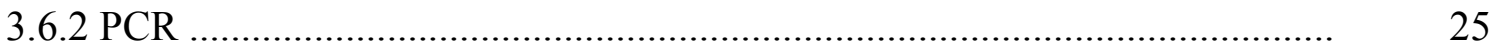

3.6.3 Construção da Mini Biblioteca de Amplicons do rDNA 18S ..................... 25

3.6.4 Sequenciamento de amplicons do rDNA 18S ........................................... 26

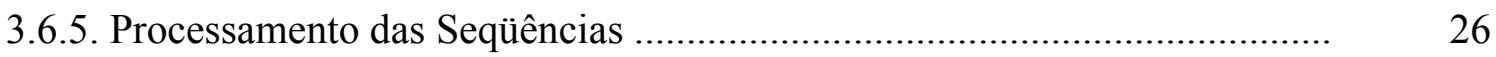

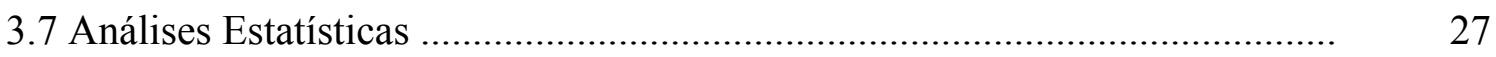

4 RESULTADOS E DISCUSSÃO ……...................................................... 28

4.1 Características Químicas do Solo das Áreas Estudadas ............................... 29

4.2 Colonização Micorrízica ......................................................................... 32

4.2.1 Aspectos Anatômicos da Colonização Micorrízica em Cupuaçu e Pupunha

4.2.2 Efeito Sazonal e do Sistema de Manejo ................................................... 34

4.3 Densidade de Esporos ....................................................................... 40

4.4 Ocorrência de Fungos MA .........................................................................

4.4.1 Ocorrência Total de Espécies ............................................................... 41

4.4.2 Freqüência de Ocorrência .................................................................... 44

4.4.3 Abundância de Esporos das Espécies de Fungos MA ................................

4.5 Diversidade das Comunidades de Fungos MA ........................................ 57

4.6 Diversidade de Fungos MA Associado às Raízes de Pupunha Avaliada pelo Sequenciamento de Mni Biblioteca de Amplicons de Região rDNA $18 \mathrm{~S}$

4.7 Considerações Metodológicas .............................................................. 75

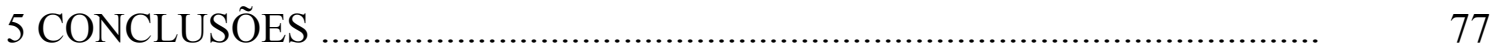

REFERÊNCIAS BIBLIOGRÁFICAS _..................................................... 


\section{LISTA DE FIGURAS}

Página

1 Esquema dos sistemas de manejo avaliados . Monocultivo de Pupunha (A), monocultivo de Cupuaçu (B) e sistema agroflorestal - SAF (C) ....................

2 Distribuição da precipitação durante o período do estudo e localização das coletas

3 Esquema de amostragem no sistema agroflorestal (SAF). (EL - entrelinha, CP - cupuaçu e PP - Pupunha). Medidas em metro

4 Sistemas de manejo estudados: a. Sistema agroflorestal, b. Monocultivo de

Pupunha e c. Monocultivo de Cupuaçu

5 Aspectos da colonização micorrízica em raízes de cupuaçu (a- arbúsculos, besporos, vesículas e micélio ;c- esporo aderido a raiz) e pupunha (d-micélio e arbúsculos; e-vesículas ; f- ponto de entrada ). Aumentos 200x (a, b, d, e, f) e 100x (c)

6 Colonização micorrízica de cupuaçu e pupunha nas estações seca e chuvosa. Médias dos monocultivos e do SAF. Numa mesma espécie, médias com mesma letra não diferem entre si (Teste $\mathrm{t}, \mathrm{p}<5 \%)$

7 Colonização micorrízica de cupuaçu e pupunha nos monocultivos e no sistema agroflorestal (SAF). Médias das duas coletas. Numa mesma espécie, médias com mesma letra não diferem entre si (Teste $\mathrm{t}, \mathrm{p}<5 \%$ )

8 Coeficientes de correlação de Pearson da colonização micorrízica de cupuaçu com os parâmetros de solo saturação por bases (S), Alumínio trocável $(\mathrm{Al})$, acidez potencial $(\mathrm{H}+\mathrm{Al})$ e capacidade de troca catiônica (CTC.). $*(\mathrm{p}<0,05) \mathrm{e}^{* *}(\mathrm{p}<0.01)$ 
9 Densidade de esporos na rizosfera de pupunha em monocultivo e em sistema agroflorestal (SAF) nas estações seca e chuvosa. Para uma mesma estação, médias com mesma letra não diferem entre si (Teste $\mathrm{t}, \mathrm{p}<5 \%$ )

10 Ocorrência de classes de freqüência de espécies de fungos MA sob o Cupuaçu (Cup), a Pupunha (Pup) e entrelinhas nos monocultivos e no SAF, nas estações seca e chuvosa. $n=9$

11 Dendrogramas de similaridade obtidos pela análise de agrupamento diferenciando os sistemas e espécies estudadas. Baseado na freqüência de ocorrência das espécies de fungos MA observados na entrelinha (Ent), no cupuaçu (Cup) e na pupunha (Pup), nos monocultivos de pupunha (PUP) e Cupuaçu (CUP), e no sistema agroflorestal (SAF) nas estações seca e chuvosa $. \mathrm{n}=9$

12 Densidade de esporos (A) e riqueza de espécies (B) das comunidades de fungos MA sob o cupuaçu, a pupunha e as entrelinhas nos monocultivos e no SAF, na estação seca. Médias com mesma letra não diferem entre si (teste $\mathrm{t}, \mathrm{p}<0,05) . \mathrm{n}=9$

13 Índices de diversidade de Shannon (A), de equitabilidade de Pielou (B) e de dominância de Simpson (C) das comunidades de fungos MA sob o cupuaçu, a pupunha e as entrelinhas nos monocultivos e no SAF, na estação seca. $n=9$

14 Densidade de esporos (A) e riqueza de espécies (B) das comunidades de fungos MA sob o cupuaçu, a pupunha e as entrelinhas nos monocultivos e no SAF, na estação chuvosa. Média com mesma letra não diferem entre si (teste $t, p<0,05) . n=9$

15 Índices de diversidade de Shannon (A), de equitabilidade de Pielou (B) e de dominância de Simpson (C) das comunidades de fungos MA sob o cupuaçu, a pupunha e as entrelinhas nos monocultivos e no SAF, na estação chuvosa. Médias com mesma letra não diferem entre si (teste $t, p<0,05) . n=9$ 
16 Relação entre riqueza (números de espécies) e densidade de esporos nas

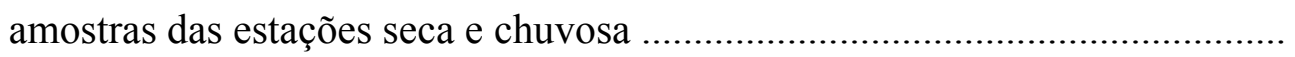

17 Relações filogenéticas entre as UTOs identificadas nas raízes de pupunha culivada em SAF, amostra um. Ar-Archaeospora; A - Acaulospora; E-Endogone; G-Glomus; Gi - Gigaspora; M-Mortierella ; SScutellopora

18 Relações filogenéticas entre as UTOs identifcadas nas raízes de pupunha cultivada em SAF, amostra dois. Ar-Archaeospora; A - Acaulospora; E - Endogone; G - Glomus; Gi - Gigaspora; M - Mortierella ; S Scutellopora

19 Análise de rarefação de seqüências de rDNA 18S de fungos MA colonizando raízes de pupunha cultivada em SAF. A - amostra um e B amostra dois 


\section{LISTA DE TABELAS}

Página

1 Características químicas do solo na entrelinha (Ent), sob o cupuaçu (Cup) e a pupunha (Pup) nos monocultivos e no sistema agroflorestal (SAF) nas estações secas e chuvosas . Médias seguidas de mesma letra na linha não

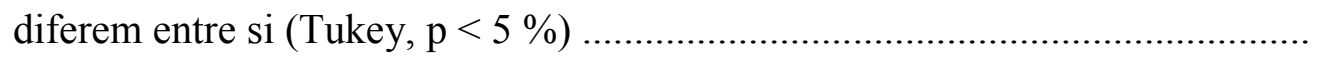

2 Espécies de fungos MA por gênero na entrelinha (Ent), sob o cupuaçu (Cup) e a pupunha (Pup) nos monocultivos e no sistema agroflorestal (SAF) nas

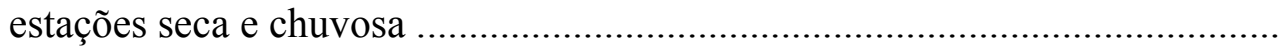

3 Freqüência relativa da ocorrência de espécies de FMA sob o cupuaçu (Cup), a pupunha (Pup) e entrelinhas (Ent), nos monocultivos e sistema agroflorestal (SAF) na estação seca

4 Freqüência relativa da ocorrência de espécies de FMA na entrelinha (Ent), no cupuaçu (Cup) e na pupunha (Pup) nos monocultivos e sistema agroflorestal (SAF) na estação chuvosa

5 Média e desvio padrão da ocorrência $\left(n^{\circ} .50 \mathrm{~cm}-3\right.$ solo) das espécies de fungos MA na entrelinha (Ent), no cupuaçu (Cup) e na pupunha (Pup) nos monocultivos e sistema agroflorestal (SAF), na estação seca ....

6 Média e desvio padrão da ocorrência (nº $.50 \mathrm{~cm}-3$ solo) das espécies de fungos MA na entrelinha (Ent), no cupuaçu (Cup) e na pupunha (Pup) nos monocultivos e sistema agroflorestal (SAF), na estação chuvosa .....

7 Coeficientes de correlação de Spearman entre características químicas do solo e a abundância de esporos de espécies de fungos MA na estação chuvosa 
8 Coeficientes de correlação de Spearman entre as abundâncias de esporos das populações de fungos MA nas amostras da estação seca .....

9. Números de sequências obtidas e similaridade com seqüências depositadas no GenBank de cada unidade taxonômica operacional (UTO) da mini biblioteca de amplicons de $18 \mathrm{~S}$ das raízes de pupunha cultivada em SAF, amostra um

10. Números de sequências obtidas e similaridade com seqüências depositadas no GenBank de cada unidade taxonômica operacional (UTO) da mini biblioteca de amplicons de $18 \mathrm{~S}$ das raízes de pupunha cultivada em SAF, amostra dois 


\title{
COMUNIDADES DE FUNGOS MICORRÍZICOS ARBUSCULARES ASSOCIADAS À PUPUNHA E AO CUPUAÇU CULTIVADOS EM SISTEMA AGROFLORESTAL E EM MONOCULTIVO NA AMAZÔNIA CENTRAL
}

\author{
Autor: JOSÉ PEREIRA DA SILVA JÚNIOR \\ Orientadora: Profa. Dra. ELKE JURANDY BRAN NOGUEIRA CARDOSO
}

\section{RESUMO}

Os solos de terra firme da Amazônia são representados em sua maioria por Latossolos e Argissolos de alta acidez e baixa fertilidade, além de serem facilmente alterados fisicamente com a substituição da floresta primária por cultivos intensivos. O uso de estratégias biológicas, entre as quais se destacam as associaçãos micorrízicas arbusculares, no aperfeiçoamento de sistemas de manejo que racionalizem o uso dos recursos naturais da região, é fundamental para o desenvolvimento econômico contínuo, socialmente justo e ambientalmente sustentável. Para tanto, é necessário melhor entendimento de aspectos ecológicos da comunidade de fungos MA, com o fim de manejá-los. Dentro desse contexto, o objetivo dessa tese foi avaliar a simbiose micorrízica e as comunidades de fungos MA associados à pupunha (Bactris gasipaes Kunth) e ao cupuaçu (Theobroma grandiflorum Willd ex Spring Schum), quando cultivados em sistema agroflorestal (SAF) e em monocultivo, além de estimar a diversidade de comunidades de fungos MA associados às raízes de pupunha através de sequenciamento de mini biblieotecas de amplicons de região do gene ribossomal 18S. Foram realizadas coletas de solo e raízes em duas estações, seca e chuvosa. A 
colonização micorrízica arbuscular no cupuaçu e na pupunha foi alterada pelo sistema de manejo adotado, sendo observadas maiores taxas de colonização no sistema de monocultivo. A dinâmica sazonal da colonização micorrízica arbuscular foi diferente em cupuaçu e pupunha. A densidade total dos esporos de fungos MA sob o cupuaçu não foi alterada pelo manejo ou pela estação. O tipo de efeito do sistema de manejo na densidade total de esporos de fungos MA sob a pupunha foi diferente nas duas estações. O número de populações de fungos MA encontrados nos agrossistemas de cupuaçu e pupunha foi elevado, com grande número de espécies de freqüência considerada rara. As espécies A. mellea, A. aff. mellea e G. macrocarpum foram as mais freqüentes no cupuaçu e na pupunha em todos os sistemas de manejo. O manejo adotado alterou a composição das comunidades de fungos MA associados à pupunha, não sendo esse efeito muito claro no cupuaçu. O cupuaçu e a pupunha apresentaram comunidades de fungos MA com alta diversidade de espécies de fungos MA, independente do sistema de cultivo. O sequenciamento de mini bibliotecca de amplicons de região do gene rDNA $18 \mathrm{~S}$ se mostrou viável na avaliação da diversidade de fungos MA, revelando alta diversidade genética desses fungos associados às raízes de pupunha. 
COMUNNITY OF ARBUSCULAR MYCORRHIZAL FUNGI ASSOCIATED WITH CUPUAÇU AND PEACH PALM IN AGROFORESTRY AND MONOCULTURE SYSTEMS IN THE CENTRAL AMAZON REGION

Author: JOSÉ PEREIRA DA SILVA JÚNIOR Adviser: Prof. Dr. ELKE JURANDY BRAN NOGUEIRA CARDOSO

\section{SUMMARY}

The upland soils from the Central Amazon region are characterized by natural low fertility and easy physical degradation due to their conversion from forest to intensive crop systems. The use of biological strategies, including the arbuscular mycorrhizal association, to improve the management of agricultural systems adapted to this environment, may be essential for the sustainable development of the Amazon region. Therefore, it is necessary to learn about ecological aspects concerning arbuscular mycorrizal fungi communities. Thus, the objective of this thesis was to evaluate the arbuscular mycorrhizal symbiosis and the arbuscular mycorrhizal (AM) fungi communities associated with peach palm (Bactris gasipaes Kunth) and cupuaçu (Theobroma grandiflorum Willd ex Spring Schum) in agroforestry systems and monoculture. Also, we aimed to estimate the diversity of the AM fungi communities in peachpalm roots by sequencing of $18 \mathrm{~S}$ rDNA amplicons to build mini library. The soil and root samples were collected in the field, in dry and rainy season. Mycorrhizal root colonization of cupuaçu and peach palm was affected by the management systems, with 
higher colonization rates observed in the monoculture systems. The seasonal dynamic of root colonization was different in cupuaçu and peach palm. The total spore density of MA fungi under cupuaçu was not affected by management systems or season. The management system effect on the total spore density of MA fungi under peach palm was different in the dry and rainy season. A high total number of MA fungi species was found in peachpalm and cupuaçu agrosystems, with mostly rare species. The species $A$. mellea, A. aff. mellea and G. macrocarpum were most common in both management systems and plant species. The AM fungi community composition associated with peachpalm was strongly affected by management systems, which did not show up clearly in cupuaçu. Cupuaçu and peach palm presented a high diversity in AM fungi communities, independent of the management systems. The sequencing of 18S rDNA amplicons mini library to estimate the diversity of the AM fungi community in peach palm roots confirmed that there is a very great diversity inside the roots, as also found in the rhizosphere. 


\section{INTRODUÇÃO}

Os solos de terra firme da Amazônia são representados em sua maioria por Latossolos e Argissolos de alta acidez e baixa fertilidade. Tais características são as maiores restrições à exploração agrícola, juntamente com o fato de esses solos serem facilmente alterados, sob o ponto de vista físico, com a substituição da floresta primária por cultivos intensivos. A utilização de técnicas convencionais de exploração agrícola nesses solos tem resultado, invariavelmente, em degradação dos mesmos, com conseqüente abandono das áreas. Além disso, o sistema tradicional de agricultura migratória vem sofrendo rupturas, modificações e substituições pelo aumento da pressão populacional, bem como por migrantes não familiarizados com os trópicos úmidos ou com as práticas de uso da terra tradicionais que permitem o cultivo de terras recém derrubadas. Isto tem resultado em períodos de pousio mais curtos, declínio da fertilidade e excessiva erosão do solo. Estima-se em cerca de 12 milhões ha as áreas abandonadas com histórico agrícola. Tais fatos têm sérias implicações sócio-econômicas e ambientais, constituindo um entrave ao desenvolvimento da região. Sob o ponto de vista ambiental, tais implicações transcendem as fronteiras da região amazônica, quer pela perda da biodiversidade, fonte de recursos genéticos para a agricultura e indústria, quer pelas possíveis alterações climáticas, resultantes da perturbação dos ciclos hidrológicos em decorrência da perda da cobertura florestal.

Nesse contexto, a busca de alternativas de manejo que racionalizem o uso dos recursos naturais da região é fundamental para o desenvolvimento econômico contínuo, socialmente justo e ambientalmente sustentável. A adoção de estratégias biológicas é uma alternativa a ser considerada no aperfeiçoamento de sistemas de manejo de nutrientes para a produção sustentada nos solos da Amazônia. Sob esse aspecto, as associações simbióticas micorrízicas arbusculares (MA) merecem especial atenção pelos 
benefícios apresentados em muitas espécies de plantas em condições de estresse, com destaque àqueles de natureza nutricional, especialmente de $\mathrm{P}$, como no caso de solos da Amazônia. No entanto, é necessário um maior entendimento dos fatores ecológicos da comunidade de fungos MA, no sentido de manejá-los, com a finalidade de se obter o máximo de benefícios desse tipo de simbiose.

A diversidade das comunidades de fungos MA pode ser um fator determinante da produtividade e da diversidade de plantas num dado ecossistema (Heijden et al., 1998 e Klironomos et al., 2000). Por outro lado, a planta pode exercer grande influência quantitativa e qualitativa na ocorrência desses fungos. Apesar da dificuldade de se estabelecer uma linha de causa e efeito desses processos ecológicos com vistas ao seu manejo, torna-se fundamental a caracterização do efeito das plantas cultivadas e de seu manejo sobre a diversificação de comunidades de fungos MA. A alteração do espectro dessas comunidades fúngicas, como resultante do manejo de culturas anuais ou herbáceas perenes, tem sido observada por vários autores (Dodd et al., 1990; Hendrix et al., 1995; Saif, 1986; Thompson, 1987). Contudo, as informações sobre o comportamento de longo prazo de comunidades de fungos MA em sistemas de cultivo envolvendo espécies perenes arbóreas são escassos no Brasil e especialmente na Amazônia.

A maioria desses estudos reporta-se à caracterização morfológica dos esporos presentes no solo. Os resultados assim obtidos dizem pouco sobre possíveis modificações da estrutura da comunidade fúngica quanto à efetiva colonização das raízes pelas espécies presentes na rizosfera. Técnicas moleculares baseadas na amplificação através da PCR (Polymerase Chain Reaction) das regiões ITS (Internal Transcript Spacer) e SSU (Small SubUnit) do gene ribossomal usando iniciadores específicos derivados de seqüências dessas regiões têm sido utilizadas na identificação de fungos MA a partir esporos ou de raízes colonizadas provenientes diretamente do campo (revisado por Harrison, 1999). Com esta abordagem poderiam ser obtidas informações mais precisas sobre a relação da comunidade de fungos MA com as espécies hospedeiras crescendo sob sistemas diferentes de cultivo. 
Considerando tais aspectos e baseado na hipótese de que sistemas de cultivo mistos alteram as relações dentro da comunidade de fungos MA e entre esses e o hospedeiro, o presente estudo objetivou avaliar a simbiose micorrízica e as comunidades de fungos MA associados a pupunha e cupuaçu quando cultivados em sistema agroflorestal e em monocultivo, além de estimar a diversidade de comunidades de fungos MA associados às raízes de pupunha através de sequenciamento de mini biblieotecas de amplicons de região do gene ribossomal 18S. 


\section{REVISÃO DE LITERATURA}

\subsection{Espécies Estudadas}

\subsubsection{O Cupuaçu (Theobroma grandiflorum Willd ex Spring Schum)}

O cupuaçu (T. grandiflorum ) é uma espécie frutífera arbórea da família Sterculiaceae, encontrando-se espontaneamente nas florestas por toda bacia Amazônica. A sua disseminação na região foi realizada possivelmente pela intensa movimentação das nações indígenas no interior da Amazônia (Cavalcante, 1996). A planta é uma árvore com altura média de seis a dez metros, podendo ocorrer até 20 metros, e diâmetro de copa em torno de quatro a sete metros. A polpa do fruto é a parte mais consumida, sendo usada para suco, doce, sorvete, iogurte, pudim, néctar, bolo e outras iguarias. As amêndoas possuem gordura de alta digestibilidade e composição típica de gorduras vegetal, similar à manteiga de cacau, constituindo numa matéria prima alternativa para o preparo de chocolate (Souza et al., 1996).

Cultura tradicional dos povos amazônidas, a sua produção até a década de 70 era caracterizada pela exploração extrativista. A partir de então, a produção de cupuaçu vem sofrendo um processo de transformação, passando desde a intensificação de seu cultivo em sistemas de produção conhecidos como "fundo de quintal", até a sua incorporação em plantios racionais, de crescente estabelecimento na última década (Andrade et al., 1998). Esse processo levou a um aumento da oferta de frutos e conseqüente queda de preços. Com isso, reduziu-se a rentabilidade obtida pelos coletores de cupuaçuzeiros nativos, desestimulando a atividade extrativista e reforçando o processo de migração da atividade de produção de cupuaçu para os plantios racionais (Homma et al., 2001). 
A produção do cupuaçu tem início no terceiro ano de cultivo, contudo é bastante irregular, com grande variação entre plantas e sendo ainda bastante sensível à variação das condições climáticas (Locatelli et al., 2001; Reisdorff et al., 2002). Na Amazônia Central, e mais especificamente na região de Manaus, a floração ocorre entre junho a setembro e a frutificação de novembro a maio, com pico de janeiro a março (Souza et al., 1996). Esse período coincide com os meses mais chuvosos observados na região (Embrapa, 1997). Em relação ao seu cultivo, é uma das espécies mais comuns em sistemas agroflorestais implantados nos últimos anos na região Amazônica (Wandelli \& Souza , 2000) e o plantio em monocultivo também vem sendo implantado na região.

O sistema radicular do cupuaçu apresenta grande proporção de raízes finas que se concentram-se na superfície, como verificada por Haag (1997). Formação de micorriza arbuscular em cupuaçu já foi registrada por Oliveira et al. (1998) e Oliveira \& Oliveira (2000). No entanto, na literatura, não foram encontradas informações sobre dependência micorrízica e tampouco sobre as espécies de fungos MA associadas ao cupuaçu.

\subsubsection{Pupunha (Bactris gasipaes Kunth)}

A pupunha (B. gasipaes) é uma espécie da família Palmae (Arecaceae), originalmente domesticada pelos ameríndios da América Central e da Amazônia. A planta é uma palmeira cespitosa, com três a cinco estipes, alcançando 20 a $25 \mathrm{~m}$ de altura e 10 a $30 \mathrm{~cm}$ de diâmetro (Souza et al. 1996). O sistema radicular da pupunheira é do tipo fasciculado, bastante superficial, com 75\% das raízes encontrando-se nos primeiros $20 \mathrm{~cm}$ de profundidade, sendo composto por raízes grossas e sem pêlos radiculares (Haag, 1997; Vandermeer, 1977).

O cultivo de pupunha adapta-se a ampla faixa de condições ecológicas, refletindo a ampla distribuição geográfica nos trópicos úmidos da América Latina. No entanto, é mais produtivo em solos bem drenados, relativamente profundos e de boa fertilidade, em altitude abaixo de $800 \mathrm{~m}$ e com pluviosidade elevada e bem distribuída (2000 - $5000 \mathrm{~mm}$ ) e temperatura acima de $24^{\circ} \mathrm{C}$ (Mora-Urpi et al., 1997). 
A pupunha pode ser cultivada para dois propósitos, a produção de frutos ou de palmito. No Brasil, os cultivos para a produção de fruto são localizados principalmente na Amazônia, onde os frutos da pupunha fazem parte da tradição alimentar regional. Para finalidade de produção de frutos nessa região, o manejo é realizado de forma tradicional, caracterizando-se por uma produção de subsistência. Normalmente, a densidade de plantas é baixa (3-20 plantas/ha), sendo o cultivo realizado em sistemas agroflorestais, do tipo "home garden", ou em áreas onde é praticada a agricultura migratória (Clement, 1989). Os plantios que objetivam a produção de palmito estendemse pelo Brasil inteiro, desde os estados da Amazônia Brasileira, passando pelos do Nordeste, Sudeste e Sul. Esses plantios caracterizam-se por adotarem normalmente o sistema de plantio em monocultivo, onde a densidade pode variar de 3000 a 20000 plantas/ha (Mora-Urpi et al., 1997). A pupunheira é uma planta perene mesmo no manejo para produção de palmito, onde é submetida a cortes periódicos. Esse diferencial em relação a outras palmeiras produtoras de palmito torna a pupunha bastante atrativa como alternativa agrícola à exploração extrativista de palmito.

Em pupunha tem sido observada a ocorrência natural de micorriza arbuscular em diferentes condições de cultivo (Bovi et al.; 1998; Janos, 1977 ; Ruiz,1993). Ensaios de inoculação com fungos micorrízicos têm demonstrado que a formação de micorriza pode ter um papel importante no desenvolvimento da pupunha. Dependência micorrízica de pupunha, baseada na relação percentual entre o peso da matéria seca de plantas inoculadas e não inoculadas, tem variado de 17 a $125 \%$, dependendo do genótipo do fungo e da planta (Carvalho, 1997; Clement \& Habte , 1995 ; Silva et al., 1998),

\subsection{Sistemas Agroflorestais}

Sistema agroflorestal (SAF) é uma forma de uso da terra na qual se combinam espécies arbóreas lenhosas com cultivos agrícolas e/ou animais, de forma simultânea ou em seqüência temporal e que interagem econômica e ecologicamente. Um aspecto que determina a sustentabilidade desses sistemas é a presença das árvores, que têm a capacidade de capturar nutrientes de camadas mais profundas do solo, reciclando-os 
eficientemente e proporcionando maior cobertura e conservação dos recursos edáficos. O sistema agroflorestal objetiva otimizar a produção por unidade de área, com o uso mais eficiente dos recursos (solo, água, luz etc), da diversificação de produção e da interação positiva entre os componentes (Nair, 1993).

A proposta desse sistema de uso da terra é aproveitar o aumento da biodiversidade como fator de equilíbrio dinâmico de ecossistemas complexos, assim como acontece em ecossistemas naturais. Contudo, tal efeito é ainda pouco estudado em sistems agrícolas. O sucesso de plantios com alta diversdade de espécies tem indicado que a biodiversidade pode ser uma ferramenta importante para o equilíbrio na interação entre as plantas, os insetos e os microrganismos (Gandara \& Kageyama, 2001).

\subsection{Fungos Micorrízicos Arbusculares}

Dentre os fenônemos bastante comuns na natureza destaca-se a formação de micorriza arbuscular (MA). Esta é uma associação íntima entre as raízes de cerca de $80 \%$ das plantas e fungos da ordem Glomales. Esta ordem de fungos é formada por cinco famílias : Glomaceae, formada pelo gênero Glomus; Acauloporaceae ,com os gêneros Acaulospora e Entrophospora ; Gigasporaceae , com os gêneros Gisgapora e Scutellospora e, mais recentemente, as famílias Archaeosporaceae e Paraglomacea, cujos representantes são os gêneros Archaeospora e Paraglomus, respectivamente (INVAM; Moreira \& Siqueira, 2002; Morton \& Benny, 1990; Morton \& Redecker, 2001).

O termo arbuscular decorre da formação no interior do córtex radicular de uma estrutura fúngica altamente dicotômica denominada de arbúsculo e que acredita-se ser o sítio de troca entre o fungo e a planta. É postulado que esta associação seja multifuncional, pelo seu papel na ciclagem de nutrientes, especialmente $\mathrm{P}$, proteção de plantas contra patógenos e seca, dentre outros efeitos benéficos. Nos últimos tempos tem-se demonstrado a ancestralidade dessa associação, o que reforça ainda mais a teoria de que possa exercer grande importância na evolução e funcionamento das comunidades vegetais (Smith \& Read, 1997). 


\subsection{Dinâmica de Comunidades de Fungos MA em Agroecossistemas}

O termo comunidade pode ser definido como um conjunto de espécies (populações) que ocorre conjuntamente em determinado tempo e dado espaço. De modo geral, o estudo das comunidades baseia-se em atributos, tais como: a composição específica ou o catálogo de espécies que compõem a comunidade; a diversidade, expressa pela riqueza de espécies, dominância e equitabilidade; a estrutura espacial; a dinâmica temporal e os fenômenos de interdependências. Dentre esses atributos, o de mais comum estudo é a diversidade (Pinto-Coelho, 2000).

Apesar do conceito de diversidade ser a princípio de fácil percepção, a sua medição tem se mostrado complexa por envolver dois componentes. O primeiro é a variedade e o segundo a abundância relativa das espécies. Portanto, diversidade pode ser medida pelo registro do número de espécies, pela descrição de sua abundância relativa ou por medidas que combinem os dois componentes (Magurran, 1988).

Porém, muitas vezes, a diversidade é equivocadamente definida baseada apenas na riqueza de espécies. Tal equívoco reside no fato de que existem comunidades que possuem alto índice de diversidade, mas com riqueza relativamente baixa de espécies, devido apresentarem alta equitabilidade, ou seja, grande homogeneidade de ocorrência numérica entre as espécies (Pinto-Coelho, 2000)

Em relação aos fungos MA, o estudo das comunidades e de suas respectivas populações é uma etapa fundamental para diferentes abordagens de pesquisa sobre micorriza arbuscular. Em sistemas naturais tais estudos podem contribuir para o entendimento da simbiose e do seu papel nos diferentes ecossistemas. Além disso, as populações autóctones constituem uma fonte primária de material para seleção de isolados, visando eficiência, dentro de um programa de obtenção de inóculo (Brundrett et al., 1996; Sieverding, 1991). Por outro lado, quando se busca manejar a simbiose MA, o conhecimento do componente fúngico é imprescindível na predição dos impactos que diferentes fatores podem exercer sobre esta simbiose.

Os fungos MA, agrupados na Ordem Glomales, perfazem mais de 150 espécies já descritas, distribuídas em seis gêneros: Acaulospora, Entrophospora, Gigaspora, 
Glomus, Sclerocystis e Scutellospora (Morton \& Benny, 1990). Mais recentemente, Morton e Redecker (2001) propuseram dois novos gêneros, Archaeospora e Paraglomus, baseados em caracteres morfológicos e moleculares.

A diversidade de comunidades de fungos MA em ecossistemas naturais não alterados está em torno de 25 espécies, enquanto em sistemas agrícolas esta diversidade tem sido reduzida (Sieverding, 1991). Contudo, mesmo em sistemas agrícolas a variação pode ser bastante pronunciada. De acordo com Douds Jr et al. (1999), o número de espécies pode variar de 3 a 34 espécies, estando essa variação relacionada ao tipo de prática agrícola e das espécies cultivadas. A rotação de cultura, por exemplo, pode exercer efeito positivo sobre a diversidade da comunidade de fungos MA, como observado por Hendrix et al. (1995) e Johnson \& Pfleger (1992). Entretanto, esse efeito pode ser dependente das espécies componentes e seqüência da rotação, como observado por Hendrix et al. (1995). Alterações na composição de espécie das comunidades podem apresentar reflexo sobre o desempenho produtivo das culturas. Os fungos MA que tornam-se predominantes em monocultivos contínuos podem contribuir para o declínio da produtividade dessas culturas. Nesse sentido, Johnson et al. (1992) observaram que esporos abundantes em monocultivos de milho (Glomus mosseae, G. ocucultum, G. agregatum e G. leptotichum) foram negativamente correlacionados com a produção de milho do cultivo subsequente, mas positivamente quando o cultivo subsequente era soja. No entanto, o mesmo comportamento não ocorria quando se tratava de parcelas sob monocultivo de soja. Os autores levantaram a hipótese de que a alteração da composição das espécies de fungos MA estaria envolvida no efeito de declínio de monocultura.

Alterações na composição de espécies nas comunidades de fungos MA podem ocorrer mesmo sem alteração da diversidade. Franke-Snyder et al. (2001) não observaram alteração da diversidade de comunidades de fungos MA em cultivos de milho e soja sob manejo de adubação convencional, adubação verde ou adubo orgânico de origem animal. Porém, algumas espécies de fungos MA tiveram sua ocorrência associada à espécie vegetal cultivada ou ao tipo de manejo adotado. Carrenho et al. 
(2001) observaram diferenças entre as espécies de fungos MA quanto à relação entre a esporulação e os atributos químicos do solo. Algumas espécies, tais como Acaulospora longula, Scutellospora fulgida, S. gilmorei e S. minuta foram mais negativamente sensíveis a concentração do $\mathrm{H}^{+}$e do $\mathrm{Al}^{3+}$ no solo. Por outro lado, a ocorrência de esporos de Glomus invermaium foi positivamente relacionada ao $\mathrm{H}^{+}$e ao $\mathrm{Al}^{3+}$. Além disso, essas espécies foram negativamente relacionadas ao conteúdo de matéria orgânica do solo, ao passo que as demais foram positivamente relacionada a esse atributo do solo.

Tais evidências provem de estudos de cultivos anuais. Todavia, o comportamento em sistemas perenes de longo prazo pode ser bastante diferente daquele encontrado para cultivos anuais. Cuenca \& Meneses (1996) verificaram que, em áreas cultivadas com cacau por mais de 40 anos, a diversidade da comunidade de fungos MA foi similar a encontrada em ecossistemas naturais intactos. Segundo os autores, nessas condições de cultivo, a diversidade foi negativamente correlacionada com o P e positivamente com matéria orgânica.

Portanto, muitos fatores podem determinar a resposta em diversidade em sistemas de cultivo, dentre esses: espécie de planta cultivada, fatores edáficos, tipo de cultivo, manejo da adubação etc. (Siqueira \& Klauberg-Filho, 2000). Essa complexidade poderia ser responsável pela variabilidade de respostas relatadas por diferentes autores.

Além do conhecimento da ocorrência de espécies individualmente, a estrutura da comunidade de fungos MA também pode ser importante. Heijden et al. (1998) estudaram o efeito da comunidade sob o ponto de vista de riqueza de espécies. Eles selecionaram aleatoriamente grupos de 1, 2, 4, 8 ou 14 espécies de fungos a partir de um grupo maior de 23 espécies isoladas de um mesmo campo que havia permanecido sem perturbação por 30 anos. As 15 espécies de plantas que ocorriam nessa área foram cultivadas num ensaio de microcosmo na presença desses diferentes grupos de fungos., O comprimento de hifas e a biomassa e a diversidade das plantas aumentaram com a diversidade de fungos, seguindo uma curva assintótica, com um ótimo em torno de 10 espécies. Este trabalho tem a inovação de estabelecer para um dado ecossistema uma referência de um nível ótimo de diversidade de comunidade de fungos MA para o seu 
funcionamento. Além disso, também estabelece que o nível de diversidade pode representar um fator mais importante que a identidade dos componentes dessa comunidade fúngica sobre o ponto de vista de funcionalidade do ecossistema. Até o trabalho de Heijden et al. (1998), o aspecto mais destacado como determinante da alteração da eficiência era a alteração da composição específica da comunidade, ou seja, a identidade das espécies dos fungos.

Como destacado anteriormente, a comunidade de fungos MA pode sofrer o impacto das atividades antrópicas. Por outro lado, a comunidade de fungos MA é um dos fatores envolvidos no efeito da micorriza em ecossistemas. Todavia, a análise do significado das mudanças na comunidade de fungos MA para a simbiose concentra-se na abordagem das populações isoladamente. Embora necessária, mostra-se incompleta, pois desconsidera as relações entre as populações dentro da comunidade.

\subsection{Técnicas Moleculares no Estudo de Comunidades de Fungos MA}

Os fungos MA constituem um grupo bastante particular de organismo. Isso em função de suas características, tais como o simbiotrofismo obrigatório, a reprodução restrita à fase assexuada e um número elevado de núcleos distintos que ocorrem num mesmo indivíduo. Tais características têm gerado muitas dificuldades para o desenvolvimento de abordagens experimentais que possibilitem o entendimento da biologia das populações e da dinâmica das comunidades.

Devido às dificuldades nos estudos dos fungos MA, usando as características morfológicas dos esporos, métodos moleculares, baseados na amplificação do DNA desses fungos via PCR começaram a ser utilizado na última década, como uma ferramenta na identificação de espécies a partir do DNA fúngico extraído de esporo ou de raiz colonizada (Sanders et al. 1995; Simon et al., 1992; Wyss \& Bonfante, 1993). Nesse sentido, várias abordagens têm sido usadas nos estudos com fungos MA, sumarizadas na Quadro 1. 


\begin{tabular}{|c|c|c|c|c|}
\hline Técnica & $\begin{array}{c}\text { Gene/Região } \\
\text { Alvo }\end{array}$ & Origem do DNA & Aplicação & Referência \\
\hline $\begin{array}{l}\text { FISH DNA- } \\
\text { DNA }\end{array}$ & ITS 2 & Esporos & $\begin{array}{l}\text { Identificação de populações } \\
\text { nucleares em monosporos }\end{array}$ & Kuhn et al., 2001 \\
\hline RFPL & ITS 1 a ITS 2 & Monoesporo & $\begin{array}{llc}\text { Identificação } & \text { de } \text { esporos } & \text { e } \\
\text { avaliação da } & \text { diversidade } & \text { de } \\
\text { comunidades. } & & \end{array}$ & $\begin{array}{l}\text { Sanders et al., 1995; Opik et } \\
\text { al., } 2003\end{array}$ \\
\hline Sequenciamento & $\begin{array}{c}\text { ITS1 a ITS2, } \\
18 \mathrm{~S}\end{array}$ & $\begin{array}{l}\text { Esporos e micélio } \\
\text { intraradicular }\end{array}$ &  & $\begin{array}{l}\text { Kowalchuk et al, 2002; } \\
\text { Opik et al., } 2003\end{array}$ \\
\hline $\begin{array}{l}\text { Primers } \\
\text { Específicos }\end{array}$ & ITS1 e ITS2 & $\begin{array}{l}\text { Esporos e micélio } \\
\text { intraradicular }\end{array}$ & Identificação taxonômica & $\begin{array}{l}\text { Souza, 2000; Lanfranco et } \\
\text { al., 2001; Morton \& } \\
\text { Redecker, } \\
\text { Schwarzott et al., } 2001\end{array}$ \\
\hline SSCP & $28 \mathrm{~S}$ & $\begin{array}{l}\text { Esporos, micélio } \\
\text { intraradicular }\end{array}$ & Identificação de isolados & $\begin{array}{l}\text { Kjoller e Rosendahl, } 2000 \text { e } \\
2001 .\end{array}$ \\
\hline Fingerprinting & Microssatélites & Esporos & $\begin{array}{l}\text { Avaliação da diversidade } \\
\text { intraespecífica }\end{array}$ & $\begin{array}{l}\text { Vandenkoornhuyse } \\
\text { Leyval, } 1999\end{array}$ \\
\hline DGGE & $18 \mathrm{~S}$ & $\begin{array}{l}\text { Esporos e micélio } \\
\text { intraradicular }\end{array}$ & $\begin{array}{l}\text { Avaliação da diversidade de } \\
\text { comunidades na raiz e no solo. }\end{array}$ & $\begin{array}{l}\text { Kowalchuk et al, 2002; } \\
\text { Opik et al., } 2003\end{array}$ \\
\hline
\end{tabular}

Quadro 1 - Técnicas baseadas em PCR e aplicações já utilizadas em estudos de diversidade de fungos MA 
A abordagem molecular tem contribuído para um considerável avanço nos conhecimentos na Taxonomia e Filogenia desses grupos de fungos. Sua utilização tem permitido maior esclarecimento sobre as relações filogenéticas, permitindo a construção de árvores filogenéticas. Simon et al. (1993) foram os primeiros a construir uma árvore filogenética de fungos MA utilizando o gene como relógio da evolução desses fungos. Para tanto, fizeram uso de seqüências do gene 18S rRNA para analisar as relações filogenéticas de 12 diferentes espécies de fungos MA, distribuídos entre os seguintes gêneros: Glomus, Entrophospora, Acaulospora, Gigaspora e Scutellospora. Posteriormente, Simon (1996) ampliou o número de espécies analisadas, chegando-se em ambos os estudos a agrupamentos coerentes com aqueles determinados em análise baseada em caracteres morfológicos preconizados por Morton (1990). Com isso, esse genes rRNA têm sido utilizados para confirmação, reavaliação ou redefinição de grupos taxonômicos (Lanfranco et al., 2001; Morton \& Redecker, 2001, Schwarzott et al., 2001).

Uma das primeiras técnicas que foi utilizada depois do sequenciamento é o RFLP. Sanders et al. (1995) propôs o uso da abordagem PCR-RFLP das regiões ITS como estratégia para a identificação de monoesporo de Glomus mosseae, Acaulospora laevis e Glomus caledonium. No estudo foram usadas cinco enzimas de restrição (HinfI, RsaI, Sau3AI, TaqI e AluI). Com o uso da técnica de RFLP os autores conseguiram diferenciar duas espécies com base nos padrões de polimorfismo baseado em apenas duas enzimas de restrição. Neste estudo também verificou-se a ineficiência do uso das enzimas de restrição TaqI e AluI.

Além do uso essencialmente taxonômico e filogenético, as técnicas moleculares tem permitido a identificação desses fungos em seu estado simbiótico, nas raízes do hospedeiro. Isto se constitui num grande avanço para os estudos de ecologia de fungos MA. Antes do advento das técnicas moleculares a identificação se restringia ao agrupamento dos fungos com base em características morfológicas do padrão de colonização micorrízica como proposto por Merryweather \& Fitter (1998), mas cuja avaliação tem elevado grau de subjetividade (Brundrett et al., 1996). 
$\mathrm{Na}$ abordagem molecular, a tecnologia da amplificação do DNA via PCR com o uso de "primers" específicos para espécies tem sido usada por diversos autores para amplificar genes de fungos crescendo na raiz do hospedeiro (Collozi-Filho e Cardoso, 2000; Jacquot et al., 2000; Redecker, 2000 e Souza, 2000). As abordagens genéticas dos "primers" têm diferido entre os vários autores. Alguns têm utilizado primers que amplificam os genes codificantes da subunidade menor ribossomal (SSU rDNA ou 18S rDNA), que são mais conservados dentro da espécie (Redecker, 2000). A região entre duas regiões não codificantes ITS1 e ITS2, que compreende também a porção codificante 5.8S, contem um grande polimorfismo de seqüência entre esporos da mesma espécie e de espécies diferentes, bem como dentro de um mesmo esporo (LloydMacgilp et al., 1996 e Sanders et al., 1995). Dentro desse polimorfismo, tem sido possível a seleção de áreas da região ITS para identificação no nível de espécie de fungos MA e uso desses primers para identificação de fungos MA colonizando raízes de planta hospedeira (Colozzi-Filho \& Cardoso, 2000 e Souza, 2000).

A aplicação das técnicas baseadas em PCR é bastante aguardada nos estudos de Ecologia e Biologia das Populações de fungos MA. A avaliação da ocorrência desses fungos tem sido dificultada enormemente por métodos tradicionais laboriosos, de longa duração, elevado nível de subjetividade e limitado as populações de espécies que esporulam no campo ou que sejam "filtradas" no processo de multiplicação em casa de vegetação. Alguns estudos têm obtido êxito usando técnicas baseadas em PCR na avaliação da diversidade de fungos MA em amostras provenientes do campo (Chelius \& Triplett, 1999; Helgason et al., 1998 e 1999; Husband et al., 2002; Johnson et al., 2004; Kjoller Rosendhal, 2001; Kowalchuk et al., 2002; Renker et al., 2003; Vandenkoornhuyse et al., 2002) . Nesses estudos tem sido utilizada a amplificação do gene 18S, 28rRNA ou ITS. Porém, a maioria tem lançado mão da análise de porções do 18S, mais especificamente da região amplificada pelos primers NS31 e AM1.

Com a evolução das técnicas moleculares, que têm se tornado mais rápidas e precisas, aliada à melhoria da especificidade dos "primers", têm permitido a aplicação dessas ferramentas em condições cada vez mais complexas. O presente estudo se propõe 
a usá-las em raízes colonizadas, possivelmente, por diferentes espécies de fungos MA e coletadas diretamente do campo. Esse seria um novo passo para a integração dessas técnicas no campo da ecologia de micorriza, contribuindo para o entendimento mais refinado das relações entre o hospedeiro e a comunidade de fungos MA.

Apesar do potencial que as técnicas moleculares possuem no estudo de fungos MA, algumas questões ainda necessitam ser esclarecidas para que sua utilização possa ser realizada sem restrição. Entre essas questões pode-se destacar a relação entre a diversidade genética e a definição de espécie, além da baixa freqüência de amplificação nas PCR, principalmente de material originado do campo, da contaminação com a comunidade microbiana introespórica, inclusive com outros fungos e da a qualidade das seqüências depositadas nos bancos públicos de genes.

A divergência na seqüência de nucleotídeos dentro de uma mesma espécie tem sido observada tanto em relação a regiões ITS menos conservadas, quanto em regiões consideradas mais conservadas, como 18S (Antoniolli et al., 2000; Clapp et al., 1999 e 2001; Kuhn et al., 2001; Lanfranco et al., 1999; Loyd-Mcgilp et al., 1996 ; Rodriguez et al., 2001; Sanders et al., 1995). Considerando que a definição das espécies de fungos MA é baseada em caracteres morfológicos, tal divergência poderia ser creditada a uma imprecisão na identificação dessas espécies estudadas. Contudo, tais estudos têm usado a extração do DNA de monoesporos. Sanders et al. (1995) verificaram a existência de dois clones distintos das regiões ITS num mesmo esporo de Glomus mosseae.

A existência de vários núcleos num único esporo é uma característica bastante conhecida de fungos MA, podendo esse número variar de $900 \mathrm{em}$ Glomus caledomium a 35.000 em Gigaspora decipiens (Burggraaf \& Boehringer 1989; Viera \& Glen 1990). Recentemente foi constatada a existência de diferentes populações nucleares em Scutellopora castanea com uso da técnica de FISH DNA-DNA (Kuhn et al., 2001).

Outros possíveis problemas que podem surgir na abordagem envolvendo PCR é a existência de uma comunidade microbiana associada aos esporos, que pode levar a erros caso os "primers" utilizados não tenham realmente grau elevado de especificidade, e a baixa qualidade dos dados depositados no bancos de seqüência de nucleotídeos, 
como o GenBank. Em relação ao primeiro caso, Helgason et al. (1998) descreveram o "primer" AM1 como específico para a amplificação de parte do gene $18 \mathrm{~S}$ de fungos da ordem Glomales e, como já destacado acima, este primer tem sido utilizado por vários autores sem o registro de inespecificidade até o momento. 


\section{MATERIAL E MÉTODOS}

\subsection{Local de Estudo}

O estudo foi desenvolvido na Embrapa Amazônia Ocidental, 29 Km da rodovia Manaus-Itacoatiara, ao norte de Manaus (38' $\mathrm{S}, 59^{\circ} 52^{\prime} \mathrm{W}, 40-50 \mathrm{~m}$ acima do nível do mar), nos anos de 2002 e 2003. A região de Manaus possui clima Af segundo classificação de Koeppen, caracterizado por temperatura média do ar de $26^{\circ} \mathrm{C}$, umidade relativa de $85 \%$ e um regime pluviométrico com média anual de $2600 \mathrm{~mm}$, com estações de características bem definidas. Os meses mais chuvosos (fevereiro e março) possuem médias em torno de $320 \mathrm{~mm}$ e os mais secos (agosto e setembro) possuem médias acima de $60 \mathrm{~mm}$ (Embrapa, 1997).

O solo da área é classificado como Latossolo Amarelo álico muito argiloso (LA), com o teor de argila, no horizonte superficial, em torno de $80 \%$, bem estruturado e originalmente ácido, com baixa capacidade de troca de cátions e baixos teores de fósforo.

\subsection{Amostragens}

Amostras de solo rizosférico e raízes da pupunha (B. gasipaes) e cupuaçu ( $T$. grandiflorum) e do solo das entrelinhas foram coletadas num experimento de longa duração, instalado em 1993, e que tem por objetivo estudar os efeitos de sistemas agroflorestais e de monoculivos sobre a dinâmica do solo e da vegetação, bem como sobre a produtividade das espécies cultivadas.

$\mathrm{O}$ experimento é conduzido numa área de 13 ha. $\mathrm{O}$ delineamento experimental a campo é de blocos ao acaso, com 3 repetições, e as parcelas têm as dimensões de $48 \mathrm{x}$ 
32m. Para as avaliações do presente estudo, coletaram-se amostras no sistema agroflorestal composto de seringueira, pupunheira e cupuaçuzeiro e nos monocultivos de cupuaçuzeiro e pupunheira. No sistema agroflorestal, além das espécies arbóreas perenes, foi cultivado mamão na entrelinha nos primeiros dois anos de cultivo. Os espaçamentos nos monocultivos de pupunha e cupuaçu são de 7,0 x 6,4 e de 2,0 x 2,0 m, respectivamente. No sistema agroflorestal (SAF), o espaçamento entre linha de cada espécie é de cinco metros e entre plantas na linha é o mesmo adotado nos respectivos monocultivos. O arranjo e os espaçamentos nesses sistemas de manejo estão esquematizados na Figura 1. Fertilizações com o uso de fontes minerais foram realizadas nos monocultivos de acordo com a recomendação da Embrapa para cada espécie. Nos sistemas agroflorestais foram aplicados fertilizantes correspondentes a $1 / 3$ da dose aplicada a cada espécie no monocultivo, baseado no pressuposto de que as interações existentes nesse sistema o tornariam mais eficiente sob o ponto de vista nutricional.

As coletas foram realizadas em duas épocas no período de um ano, caracterizadas como estação seca e chuvosa. Além do regime pluviométrico do período de estudo levou-se em consideração também a fenologia do cupuaçu, que como já mencionado anteriormente, tem sua frutificação justamente no período chuvoso. A primeira coleta, correspondente à estação seca, foi realizada na entre safra do cupuaçu, no final do mês de julho de 2002 (Figura 2) e a segunda, correspondente à estação chuvosa e durante a safra de cupuaçu, foi realizada em meados de maio de 2003. 

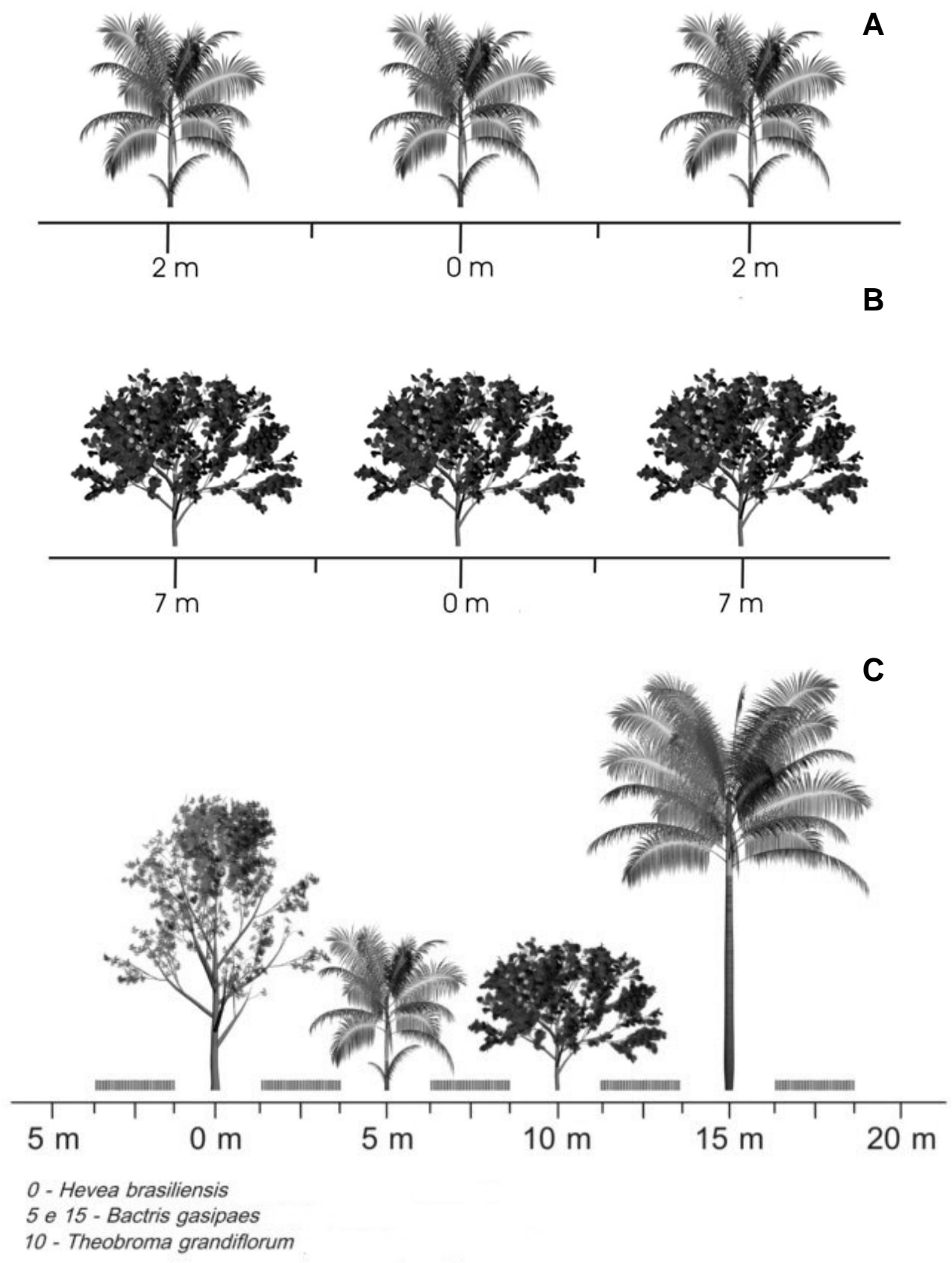

Figura 1 - Esquema dos sistemas de manejo avaliados . Monocultivo de Pupunha (A), monocultivo de Cupuaçu (B) e sistema agroflorestal - SAF (C) 


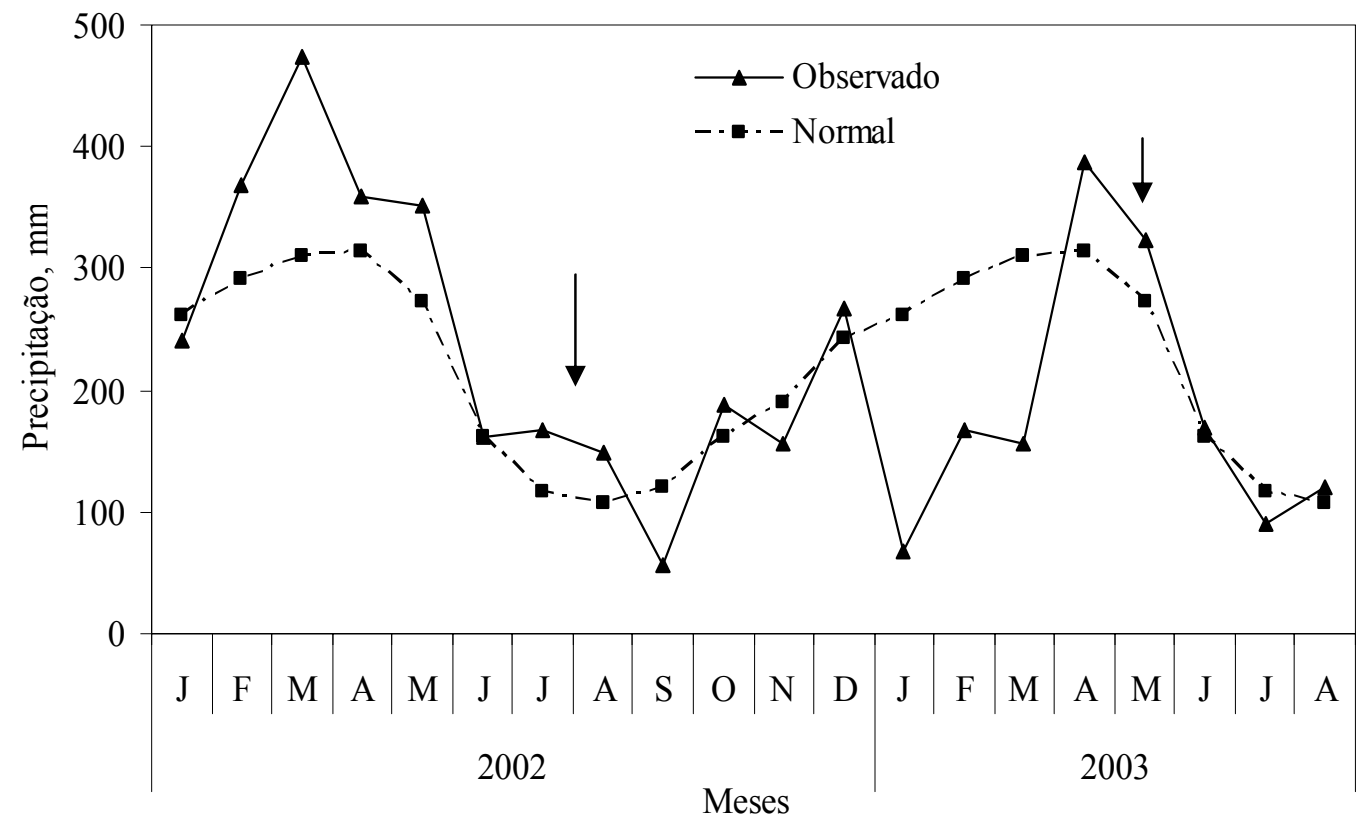

Figura 2 - Distribuição da precipitação durante o período do estudo e localização das coletas

Foram coletadas três amostras por parcela para cada espécie nos sistemas de manejo estudados, a uma profundidade de $10 \mathrm{~cm}$, com cerca de $600 \mathrm{~g}$ de solo e raízes. Além das amostragens sob as árvores, foram realizadas coletas na entrelinha. (Figura 3). Sob cada planta de cupuaçu e pupunha foram coletadas quatro subamostras sob a projeção da copa, distribuídas aleatoriamente a cerca de $50 \mathrm{~cm}$ do colo da planta. As amostragens das entrelinhas foram retiradas na maior distância das árvores no monocultivo de pupunha e SAF, sendo que no monocultivo de cupuaçu tomaram-se amostras na mesma distância do SAF (2,5 m das árvores). 




Figura 3 - Esquema de amostragem no sistema agroflorestal (SAF). (EL - entrelinha, $\mathrm{CP}$ - cupuaçu e PP - Pupunha). Medidas em metro

\subsection{Avaliações}

Nas amostras de solo foram avaliadas a densidade de esporos e a composição da comunidade de fungos MA, além das características químicas do solo. Nas raízes de pupunha e cupuaçu avaliou-se a colonização micorrízica.

\subsubsection{Levantamento de Espécies de Fungos MA}

Para a determinação da densidade de esporos, procedeu-se à sua extração do solo por peneiramento úmido de acordo com Gerdemann \& Nicolson (1963) e centrifugação em sacarose $70 \%$ a $2000 \mathrm{rpm}$ por 3 minutos (Jenkins, 1964). Para a avaliação da composição da comunidade de fungos MA, os esporos colhidos em peneira de malha de cerca $30 \mu \mathrm{m}$ foram transferidos para lâminas contendo resina PVLG (álcool 
polivinil lacto-glicerol ) com o auxílio de agulha embebida na mesma resina. Fez-se então a separação em grupos de acordo com as semelhanças morfológicas. Os esporos de cada grupo foram fixados em lâminas semi permanentes com PVLG e numa mistura PVLG/reagente de Melzer (Schenck \& Perez 1987). Através da observação em microscópio óptico (100x a 600x), avaliaram-se as características morfológicas: tamanho, cor, forma, tipo de hifa esporígena e estrutura e ornamentação da parede. Foram considerados apenas os esporos viáveis (com conteúdo celular) para a contagem de esporos total e de cada tipo morfológico.

A identificação das espécies foi realizada com base nessas características morfológicas de acordo com Schenck \& Perez (1987) e Morton \& Beny (1990), e pelas descrições obtidas no banco de dados do INVAM (International Culture Collection of (Vesicular) Arbuscular Mycorrhizal Fungi).

\subsubsection{Colonização Micorrízica}

A colonização micorrízica foi determinada através do seguinte procedimento: as raízes foram clarificadas e coloridas de acordo com metodologia descrita por Vierheilig et al. (1998) e a percentagem de colonização estimada pelo método da placa quadriculada em microscópio estereoscópico (Giovannetti \& Mosse, 1980) para o cupuaçu e pela avaliação de 80 segmentos de raízes observados em microscópio óptico (aumento 100x) para as raízes de pupunha.

\subsubsection{Caracterização Química do Solo}

O solo foi caracterizado químicamente de acordo com metodologias propostas pela Embrapa e descritas por Silva (1999), seguindo os procedimentos: $\mathrm{Ca}^{+2}, \mathrm{Mg}^{+2} \mathrm{e}$ $\mathrm{Al}^{+3}$ extraídos por $\mathrm{KCl}$ e determinados por absorção atômica $\mathrm{o} \mathrm{Ca}^{+2} \mathrm{e} \mathrm{Mg}^{+2}$, e por titulação o $\mathrm{Al}^{+3} ; \mathrm{H}+\mathrm{Al}$, extraídos com acetato de Ca e determinados por titulação; $\mathrm{P}$ e $\mathrm{K}^{+}$, extraídos com solução de Mehlich I e determinado o K por fotometria de chama e o 
P por colometria ; C orgânico, determinado por oxidação úmida em dicromato de potássio, com o conteúdo de matéria orgânica estimada multiplicando-se o conteúdo de C por 1,724 .

\subsection{Parâmetros da Estrutura das Comunidades de Fungos MA}

A partir dos dados de ocorrência e abundância das espécies de fungos MA encontradas nas amostras, definiu-se a estrutura da comunidade desses organismos com base nos seguintes índices:

Riqueza $=\mathrm{S}=$ número de espécies encontradas na amostra

Diversidade de Shannon $=H^{\prime}=-\sum\left[\left(\frac{n_{i}}{n}\right) \ln \left(\frac{n_{i}}{n}\right)\right]$ (Magurran, 1988)

Equitabilidade de Pielou $=E=\frac{H}{\ln S}($ Magurran, 1988)

Dominância de Simpson $=\sum\left(\frac{n_{i}}{n}\right)^{2}$ (Magurran, 1988)

onde: $\mathrm{n}_{\mathrm{i}}=$ número de esporos da i-ésima espécie presente na amostra

$\mathrm{n}=$ número total de esporos da amostra

$\mathrm{S}=$ número total de espécies presentes na amostra

\subsection{Freqüência Relativa de Ocorrência das Espécies de Fungos MA}

Com base nos dados de ocorrência, foi calculada a freqüência relativa para cada espécie da seguinte forma: Freqüência Relativa $(\%)=\mathrm{FR}_{i}=\left(\frac{n_{i}}{N}\right) 100$

Onde: $n_{i}=$ número de amostras onde a $i$-espécie foi encontrada $\mathrm{N}=$ número total de amostras 


\subsection{Avaliação da Diversidade de Fungos MA em Raízes de Pupunha Através de Mini Biblioteca de Amplicons de Região do rDNA 185}

$\mathrm{Na}$ coleta da estação seca, amostras de raízes de pupunha foram lavadas em água destilada estéril e congeladas a $-20^{\circ} \mathrm{C}$, sendo posteriormente transportadas em gelo seco e armazenadas a $-80^{\circ} \mathrm{C}$ até a extração de DNA.

\subsubsection{Extração de DNA Total das Raízes}

As raízes previamente congeladas a $-80^{\circ} \mathrm{C}$ foram moídas em almofariz na presença de nitrogênio líquido. Depois de homogeneizados foi retirada uma alíquota de cerca de $500 \mathrm{mg}$. O DNA total da amostra foi extraído com o uso do kit FastDNA Spin (Bio 101, Vista, Califórnia), de acordo com as instruções do fabricante. Em microtubos de 1,5 mL foram adicionados $800 \mu \mathrm{L}$ de solução de lise para tecidos vegetais (CLSVF) e $100 \mu \mathrm{L}$ de tampão PBS e duas esferas plásticas de $1 / 4$ de polegada. Os tubos foram agitados horizontalmente por $20 \mathrm{~s} \mathrm{a} 4 \mathrm{~m}^{-1}{ }^{-1}$ num homogeinizador FP120 Fast Prep Cell Disruptor (Bio 101, Vista, California). Procedeu-se então uma centrifugação por 10 min a $13.000 \mathrm{rpm}$, transferiram-se $600 \mu \mathrm{L}$ do sobrenadante para um microtubo limpo de 1,5 $\mu \mathrm{l}$ e adicionaram-se $600 \mu \mathrm{l}$ da matriz de ligação. Seguiu-se uma agitação através da inversão dos tubos por 20 vezes, incubando-se em seguida por cinco minutos a temperatura ambiente. Centrifugou-se por um minuto à velocidade de $13.000 \mathrm{rpm}$ e descartou-se o sobrenadante. O pélete foi ressolubilizado em $500 \mu \mathrm{L}$ da solução de lavagem (SEWS). Transferiu-se a solução para um filtro (Spin Filter ${ }^{\circledR}$ ) acoplado a um microtubo e o conjunto foi centrifugado por duas vezes a $13.000 \mathrm{rpm}$ por um minuto. $\mathrm{O}$ filtro foi transferido para um microtubo limpo. Foram adicionados $50 \mu \mathrm{L}$ de solução DES à matriz de ligação e mexeu-se cuidadosamente a matriz para que a mesma fosse hidratada. Incubou-se por cinco minutos à temperatura ambiente e centrifugou-se a 13.000 rpm e colheu-se o filtrado contendo o DNA em solução de DES. O material foi armazenado a $-20^{\circ} \mathrm{C}$, até ser usado. 


\subsubsection{PCR}

Para a reação de PCR selecionaram-se os "primers" para amplificação da região 18S dos fungos MA, AM1 (5'- GTT TCC CGT AAG GCG CCG AA- 3'), descrito por Helgason et al. (1998), e o NS31 (5'- TTG GAG GGC AAG TCT GGT GCC -3') descrito por Simon et al. (1992). A reação foi feita em $50 \mu \mathrm{L}$ de volme final, contendo $0.2 \mathrm{mM}$ de cada dNTP, $1,5 \mathrm{mM}$ de $\mathrm{MgCl}_{2}, 10$ pmol de cada "primer", $1 \mathrm{U}$ de Taq DNA Polimerase (Invitrogen), $5 \mu \mathrm{L}$ de tampão para PCR 10x e $2 \mu \mathrm{L}$ do DNA obtido de acordo com o item anterior. A amplificação foi realizada em um termociclador Mastercycler Gradient (Eppendorf), nas seguintes condições: desnaturação incial durante 2 min a $94^{\circ} \mathrm{C} ; 35$ ciclos de desnaturação a $92^{\circ} \mathrm{C}$ por $30 \mathrm{~s}$, pareamento a $60^{\circ} \mathrm{C}$ por $60 \mathrm{~s}$ e extensaõ a $68{ }^{\circ} \mathrm{C}$ por $45 \mathrm{~s}+1 \mathrm{~s}$ por ciclo; extensão final a $68{ }^{\circ} \mathrm{C}$ por $5 \mathrm{~min}$. Uma alíquota dos produtos da PCR (amplicons) foi analisada através de eletroforese em gel de agarose a 1,0\% em TBE 0,5X. Como padrão de quantidade e tamanho do DNA foi utilizado o marcador de massa DNA Mass Ladder (Gibco).

\subsubsection{Construção da Mini Biblioteca de Amplicons do rDNA 18S}

Os produtos da PCR foram purificados utilizando-se o Kit GFX Purification System (Amersham) antes da ligação em vetores de clonagem. A clonagem foi feita com Kit pGem ${ }^{\circledR}$ - Easy Vector (Promega) de acordo com as recomendações do fabricante. A reação de ligação foi realizada num volume final de $10 \mu \mathrm{L}$, contendo $50 \mathrm{ng}$ do vetor, cerca de $25 \mathrm{ng}$ de inserto, $5 \mu \mathrm{l}$ de tampão de ligação, $1 \mu \mathrm{L}$ de T4 DNA ligase e água ultrapura estéril para completar o volume final, mantida a temperatura ambiente por quatro horas. $\mathrm{O}$ produto da reação de ligação foi utilizado para transformar células competentes de E. coli.. A introdução do vetor contendo o inserto nas células

competentes de E. coli DH5a foi feita através de choque térmico (Sambrook et al., 1989). Os $10 \mu \mathrm{L}$ do produto da reação de ligação e $100 \mu \mathrm{L}$ de suspensão de células competentes de E. coli DH5 a foram misturados em um microtubo esterilizado, o qual foi incubado no gelo durante 30 minutos. O microtubo foi então transferido imediatamente para banho-maria a $42^{\circ} \mathrm{C}$ e deixado por $45 \mathrm{~s}$ sem agitação. Procedeu-se a adição de 250 
$\mu \mathrm{L}$ de meio SOC (Sambrook et al., 1989) à temperatura ambiente e incubou-se a $37^{\circ} \mathrm{C}$ por uma hora, sob agitação de $200 \mathrm{rpm}$. As células competentes foram então plaqueadas em meio LB sólido contendo ampicilina e X-GAL, ambos em concentrações finais de

$100 \mu \mathrm{g} . \mathrm{mL}^{-1}$ de meio. As placas foram incubadas por cerca de 14 horas a $37^{\circ} \mathrm{C}$. Foram selecionadas 96 colônias transformadas (brancas) e transferidas para crescer em miniplacas contendo $5 \mathrm{ml}$ de meio LB líquido e $2 \mu \mathrm{L}$ de ampicilina $\left(0,05 \mathrm{~g} \cdot \mathrm{mL}^{-1}\right)$, sendo cultivadas por cerca de $14 \mathrm{~h}$ a $37^{\circ} \mathrm{C}$ sob $200 \mathrm{rpm}$ de agitação.

O plasmídeo foi extraído por lise alcalina e alguns clones foram selecionados para análise em gel de agarose 1\% em TBE 0,5X para quantificação.

\subsubsection{Sequenciamento de amplicons do rDNA $18 \mathrm{~S}$}

A amplificação dos insertos foi realizada por PCR com a enzima Thermo Sequence II DNA polymerase e "DYEnamic Terminator" (Amersham) conforme recomendações do fabricante, utilizando-se o "primer" M13F. O sequenciamento foi feito em sequenciador capilar Applied Biosystems (model 3100), de acordo com as recomendações do fabricante.

\subsubsection{Processamento das Seqüências}

As seqüências obtidas foram processadas para remoção do vetor utilizando-se os programas Phred/Phrap (Ewing et al., 1998; Ewing \& Green, 1998). O agrupamento das seqüências em unidades taxonômicas operacionais (UTO) foi realizado no programa CAP3 (Huang \& Madan, 1999), tendo como parâmetros de alinhamento 150 bases e identidade maior que $97 \%$. As seqüências consensos das UTO, bem como aquelas que não formaram grupos (singletons) foram comparadas com seqüências depositadas no GenBank (NCBI ) para identificação da espécie fúngica. A árvore filogenética foi construída através do programa ClustalX (Thompson et al., 1997), 


\subsection{Análises Estatísticas}

Os resultados foram testados quanto à homogeneidade de variância, submetidos às transformações pertinentes e posteriormente à análise de variância. Aplicou-se o teste de médias de Tukey ou $t$ de Student para os fatores ou desdobramentos das interações signifcativas.

Os dados de freqüência relativa de ocorrência das espécies de fungos MA nos sistemas e espécies de plantas estudadas foram submetidos à Análise Multiviariada de Agrupamento, utilizando como medida de similiridade/dissimilaridade a distância Euclideana, através da técnica de agrupamento hieráquico, pelo método da Variância Mínima ou de Ward. No método de Ward ou da variânica mínima os grupos são formados de maneira a proporcionar o mínimo de aumento da variância intragrupo. A variância é calculada para todas as alternativas de agrupamento, escolhendo-se o que proporciana a menor variância. Este método é considerado o mais eficiente para análise de agrupamento (Valentin, 2000). Para essa análise foi utilizado o aplicativo estatístico Statistica ${ }^{\circledR}$. 


\section{RESULTADOS E DISCUSSÃO}

Um aspecto geral dos sistemas de manejo estudados pode ser visto na Figura 4.
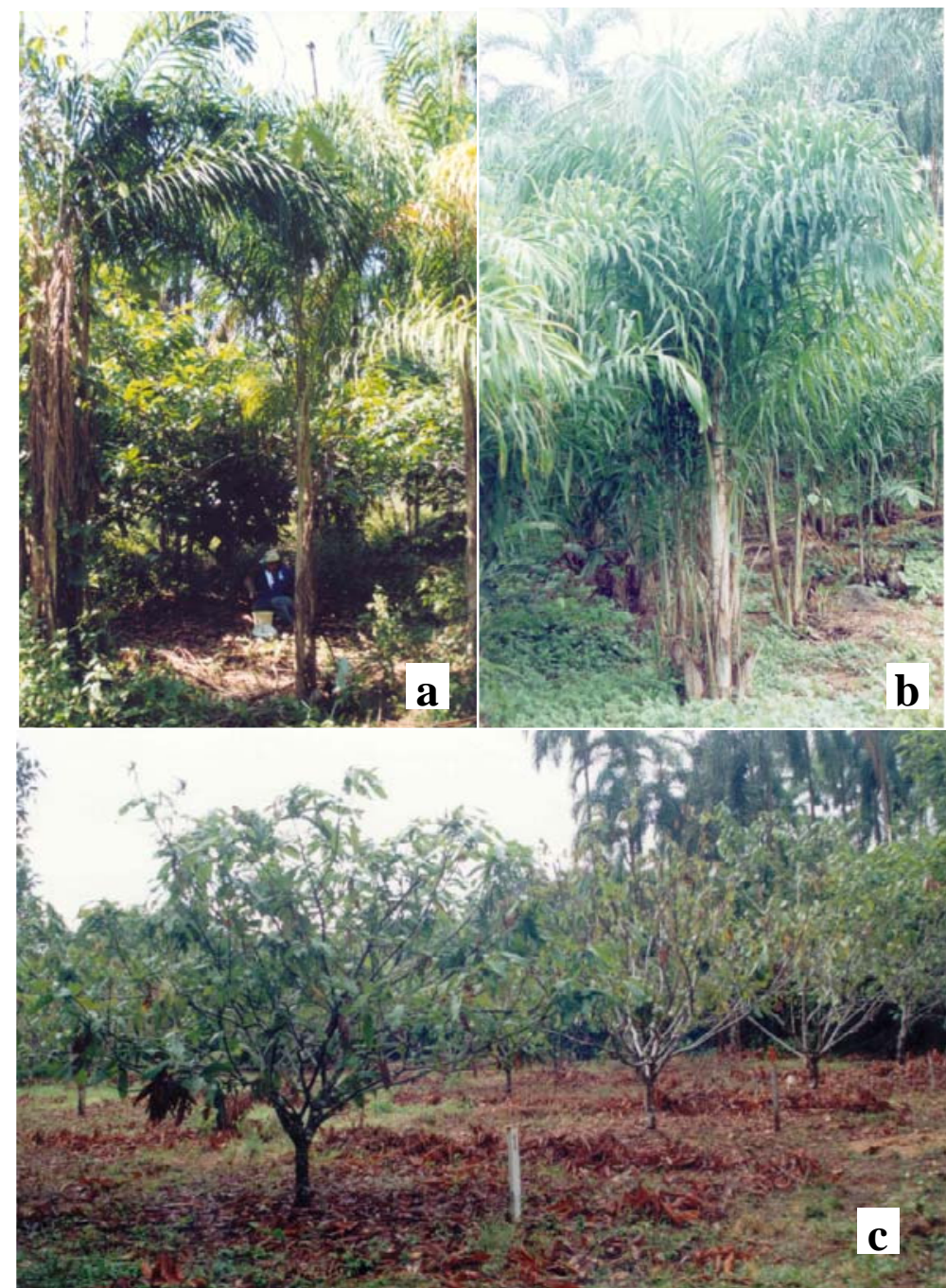

Figura 4 - Sistemas de manejo estudados: a. Sistema agroflorestal, b. Monocultivo de Pupunha e c. Monocultivo de Cupuaçu 


\subsection{Características Químicas do Solo das Áreas Estudadas}

$\mathrm{Na}$ Tabela 1 são apresentadas as características químicas dos solos das áreas sob o cupuaçu, a pupunha e nas entrelinhas nos sistemas de monocultivos e no SAF, nas duas estações do ano. Apesar das diferenças apresentadas entre os sistemas de manejo e a posição de coleta, o solo na camada superficial dessas áreas em geral foi ácido, com elevado teor de matéria orgânica (M.O.), baixos teores de bases trocáveis e saturação por bases trocáveis e elevada acidez potencial $\left(\mathrm{H}^{+}+\mathrm{Al}^{+3}\right)$.

No SAF não ocorreram diferenças significativas na maioria das características químicas do solo sob o cupuaçu, a pupunha e a entrelinha, à exceção do pH e da CTC na estação seca. Nessa estação, o solo foi mais ácido sob o cupuaçu e a pupunha do que na entrelinha de cultivo. Por outro lado, a CTC foi mais elevada sob o cupuaçu do que sob a pupunha e na entrelinha. $\mathrm{O}$ solo da área do experimento possui alto conteúdo de argila, com variação em torno de 60-75\% (Rodrigues et al., 1972), cuja mineralogia é composta principalmente de caulinita (Silva, 1997). A caulinita possui uma baixa CTC (Sanches, 1981), levando a crer que as diferenças de CTC observadas possam estar relacionadas à qualidade da matéria orgânica proporcionada pela serapilheira de cupuaçu, pupunha e da vegetação espontânea. Uguen et al., (2002) já observaram diferenças na qualidade da serapilheira de cupuaçu e pupunha, considerando a composição de nutrientes.

Os teores de P nas estações seca e chuvosa e de K na estação chuvosa foram maiores sob a pupunha cultivada em monocultivo do que na sua respectiva entrelinha. $\mathrm{O}$ cupuaçu cultivado em monocultivo também apresentou maiores teores de $\mathrm{P}$, bem como de Ca nas duas estações quando comparado à entrelinha.

Nas duas estações, os teores de P no solo diferiram significativamente entre os sistemas de manejo em ambas as espécies, com os monocultivos apresentando valores maiores. Também houve diferenças significativas nesses teores entre o cupuaçu e a pupunha, quando cultivados em monocultivos, porém isso não ocorreu quando o cultivo se deu no SAF. Nos monocultivos também houve, significativamente, menores teores de $P$ na entrelinha de cultivo em ambas as espécies.

De modo geral, as principais diferenças entre os pontos amostrados foram verificados principalmente entre a linha e a entrelinha dos sistemas de monocultivos e entre os sistemas de manejo numa mesma espécie. Isto reflete as diferenças de 
quantidade de adubos minerais historicamente aplicados nos dois sistemas de manejo nos 9 anos de cultivo. Convém lembrar que no SAF é aplicada, por espécie, um terço da quantidade de adubo mineral aplicada nos sistemas de monocultivo.

Alterações na fertilidade do solo entre níveis diferentes de adubação em SAF, semelhantes aos estudados nesse trabalho já foram observadas por Schroth et al. (2000). Apesar de não terem sido realizadas adubações durante o ano de coleta, efeito residual do histórico de adubações pôde ser observado principalmente com relação ao $\mathrm{P}$, nas duas espécies, e ao Ca no cupuaçu. No caso do $\mathrm{P}$, a sua baixa mobilidade proporcionaria um maior tempo de permanência nos sistemas. Já em relação ao Ca, o efeito residual só foi observado sob o cupuaçu mas não sob a pupunha. Isto decorre possivelmente da menor taxa de escorrimento de tronco observada nessa espécie quando comparada à pupunha (Schroth et al., 1999), o que implicaria em menor fluxo de água na área próxima ao colo da planta, reduzindo, assim, as perdas de $\mathrm{Ca}$ por lixiviação. Isto poderia estar possibilitando que o $\mathrm{Ca}$ aplicado nas adubações e calagem permanecesse no sistema por mais tempo. Além disso, a serapilheira de cupuaçu é mais rica em Ca (Uguen et al., 2002), o que poderia estar possibilitando taxas maiores de reciclagem de $\mathrm{Ca}$ sob o cupuaçu, contribuindo assim para a redução das perdas desse nutriente do sistema. 
Tabela 1. Características químicas do solo na entrelinha (Ent), sob o cupuaçu (Cup) e a pupunha (Pup) nos monocultivos e no sistema agroflorestal (SAF) nas estações secas e chuvosas. Médias seguidas da mesma letra na linha não diferem entre si (Tukey, $\mathrm{p}<5 \%$ )

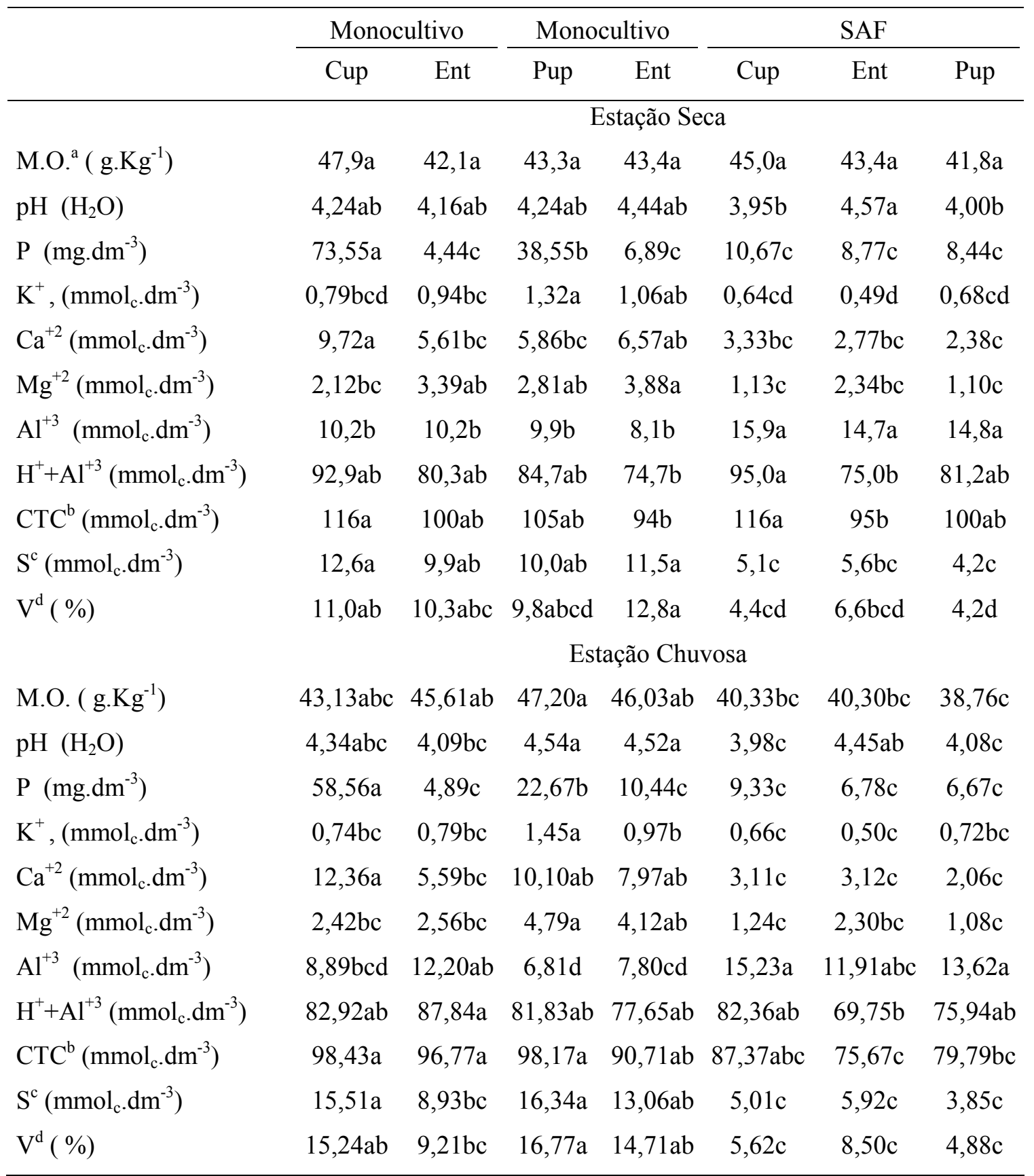

a. Matéria orgânica; b. Capacidade de troca cationnica; c. Soma de bases; d. Saturação por Bases 


\subsection{Colonização Micorrízica}

\subsubsection{Aspectos Anatômicos da Colonização Micorrízica em Cupuaçu e Pupunha}

Não há estudos anteriores descrevendo a anatomia das micorrizas arbusculares em pupunha e cupuaçu. Nas raízes de pupunha e de cupuaçu foi possível a visualização e identificação de várias estruturas de colonização micorrízica arbuscular (Figura 5). Na pupunha identificou-se nas células epidermiais a formação de apressórios, esporos na superfície das raízes, enquanto que no interior das células corticais verificou-se a formação tanto de arbúsculos típicos quanto de hifas enoveladas ou pelotões.

De acordo com a descrição de Smith \& Read (1997), a presença de arbúsculos típicos, resultante da intensa ramificação dicotômica no interior das células do córtex do hospedeiro, é uma característica de colonização do tipo Arum. Por outro lado, a presença mais abundante de pelotões e hifas enoveladas no interior das células do córtex é característica do padrão de colonização tipo Paris. Portanto, nas raízes de pupunha os padrões de colonização tipos Arum e Paris podem estar ocorrendo simultaneamente. Já no cupuaçu a colonização micorrízica foi caracterizada pelo crescimento de hifa inter e intracelular, com formação de arbúsculos no interior de células adjacentes. No entanto, não foi observada a formação de hifas enoveladas ou pelotões no interior das células. Esse padrão de colonização enquadra-se no tipo Arum. A formação de vesículas foi verificada nas raízes tanto do cupuaçu como da pupunha, evidenciando a presença de espécies de fungos da subordem Glomineae entre os fungos simbiontes.

A colonização micorrízica em pupunha registrada nesse estudo assemelha-se ao padrão de colonização observada por Fisher \& Jayachandran (1999) nas raízes da palmeira Serenota repens (Bartr.). Foi verificado que as raízes de ambas as palmeiras caracterizam-se por uma espessa camada de células epidermiais que dificulta a visualização da colonização micorrízica da pupunha, o que pode explicar os valores baixos de colonização micorrízica em pupunha observados por Feldmann et al. (1995) quando comparados aos valores apresentados nesse estudo. A observação da colonização das células do córtex nesse estudo só foi possível depois do rompimento da epiderme. Para tanto, na confecção das lâminas procedeu-se ao esmagamento das raízes. Silva et al. (1998) e Costa (informação pessoal) também registraram a dificuldade na observação 
da colonização micorrízica nas raízes de pupunha. Outra modificação realizada para a melhor coloração das raízes foi uma pré-descoloração em KOH (10\%) durante 14 h em temperatura ambiente.

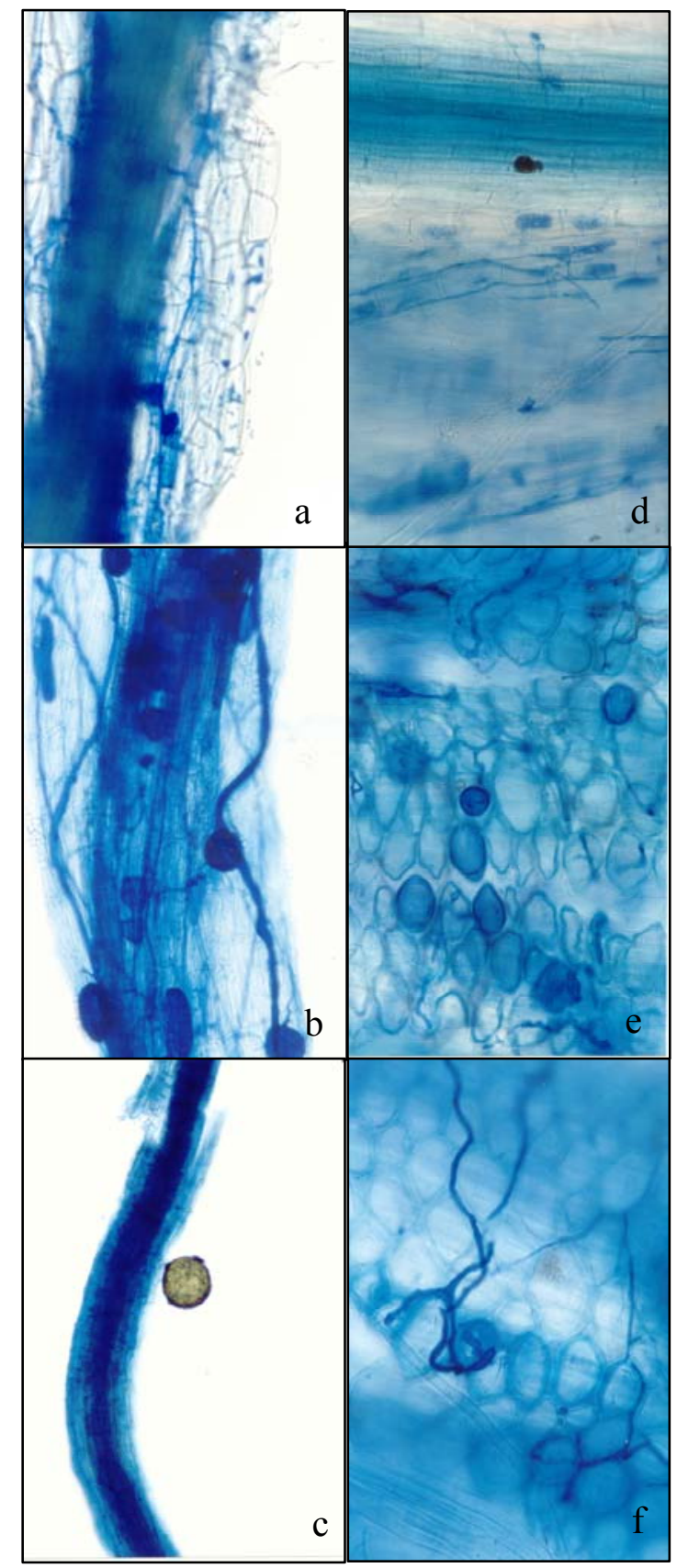

Figura 5 - Aspectos da colonização micorrízica em raízes de cupuaçu (a- arbúsculos, besporos, vesículas e micélio; $\mathbf{c}$ - esporo aderido à raiz) e pupunha (d-micélio e arbúsculos; e-vesículas ; f- ponto de entrada ). Aumentos 200x (a, b, d, e, f) e 100x (c) 
A observação simultânea dos dois tipos de padrão de colonização micorrízica (Arum e Paris) contraria Smith \& Smith (1997), cuja revisão propõe apenas um tipo de padrão de colonização por espécie, o qual seria característico do grupo taxonômico do hospedeiro. $\mathrm{Na}$ família da pupunha (Arecaceae) há espécies representantes dos dois padrões de colonização. Apesar de proporem um padrão intermediário entre os tipos Arum e Paris, os autores não mencionam a possibilidade da ocorrência simultânea dos dois padrões de colonização. Contudo, é razoável supor a ocorrência de mais de um tipo de padrão de colonização nas condições desse estudo considerando que: o tipo de colonização seria influenciado pela identidade do fungo simbionte, como comprovado por Cavagnaro et al. (2001); pode haver mais de uma espécie de fungo colonizando as raízes, como indicam os dados de ocorrência de fungos baseados nos esporos presentes na rizosfera.

No cupuaçu, a colonização micorrízica caracterizou-se pela formação de arbúsculos típicos e a presença de vesículas e esporos no interior das raízes. Não foi observada a formação de hifas enoveladas. Portanto, o cupuaçu apresentou apenas um padrão de colonização, muito embora na sua família (Sterculiaceae) tenha sido registrada a ocorrência da classe intermediária entre os tipos Arum e Paris (Smith \& Smith, 1997).

\subsubsection{Efeito Sazonal e do Sistema de Manejo}

Quanto à extensão da presença dos fungos MA nas raízes, a taxa de colonização micorrízica variou de 5,5 a 23,5\% no cupuaçu e de 10,5 a 45,5\% na pupunha. Estes valores estão próximos daqueles observados em estudos de campo por Oliveira et al. (1998) e Oliveira \& Oliveira (2000) no cupuaçu, e Bovi et al. (1998) na pupunha.

Nas duas espécies estudadas, cupuaçu e pupunha, o "status" da micorrização foi afetado pela estação do ano e sistema de manejo $(\mathrm{p}<0.05)$, porém não ocorreu interação entre esses fatores. No cupuaçu a maior colonização micorrízica foi observada na estação chuvosa, enquanto que na pupunha a colonização micorrízica foi maior na estação seca (Figura 6). 
A diferença dos padrões sazonais da colonização entre o cupuaçu e a pupunha indicaria que os fatores determinantes da sazonalidade do "status" micorrízico dessas espécies podem ser distintos. O aumento da colonização micorrízica do cupuaçu na estação chuvosa também foi observada por Oliveira et al. (1998). Os referidos autores encontraram uma relação linear entre colonização micorrízica e umidade do solo. Contudo, é necessário ressaltar a possibilidade do efeito sazonal ocorrer através da planta. Allen et al. (1998), em estudo realizado nos trópicos mexicanos, também observaram, em várias espécies florestais, maiores taxas de colonização na estação chuvosa. Contudo, os autores relacionaram tal característica à maior atividade de raiz nessa época do ano na maioria das espécies estudadas.

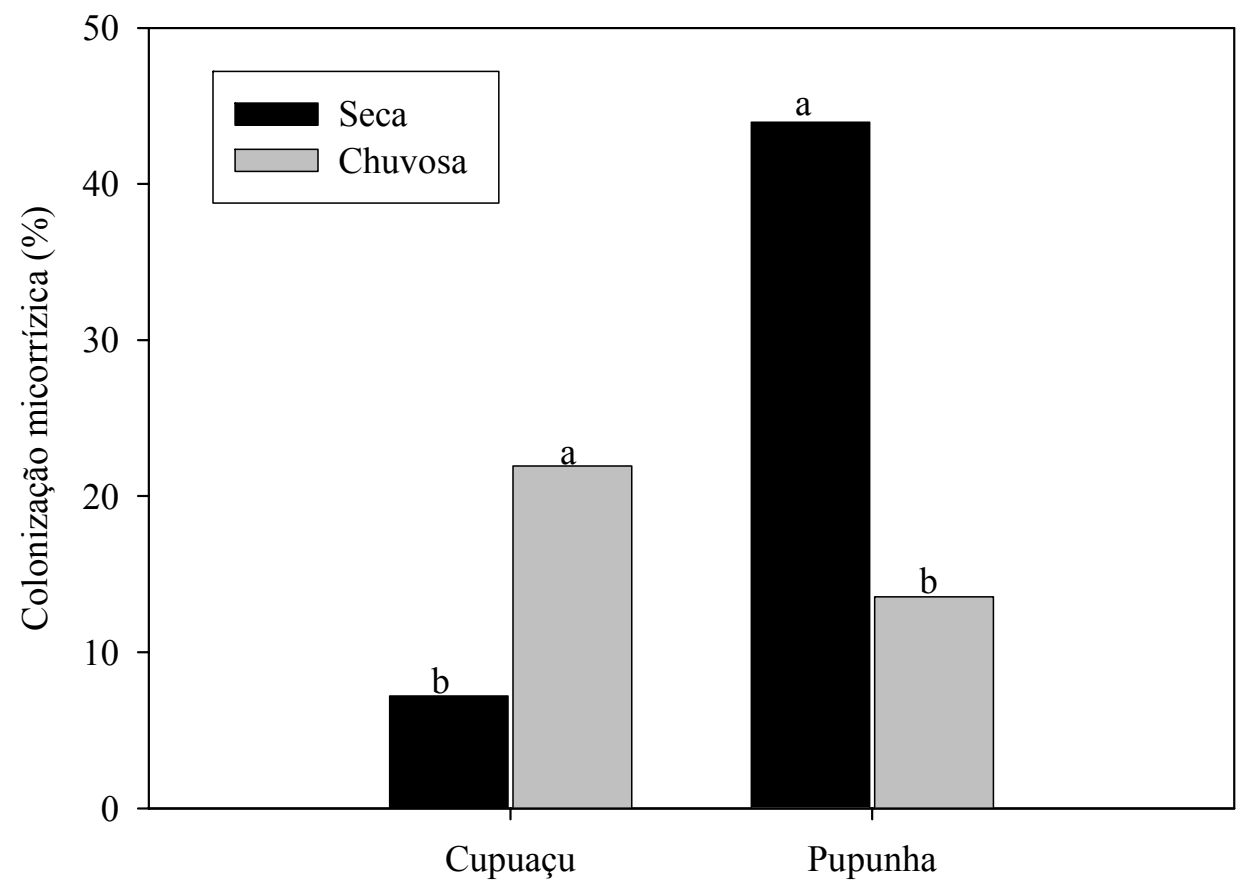

Figura 6 - Colonização micorrízica de cupuaçu e pupunha nas estações seca e chuvosa. Médias dos monocultivos e do SAF. Numa mesma espécie, médias com mesma letra não diferem entre si (Teste $t, p<5 \%$ ) 
O padrão sazonal da pupunha diferiu daquele observado no cupuaçu (Figura 6). Isto, porém, não contradiz a hipótese acima levantada como mecanismo de regulação que estaria atuando no cupuaçu. Maior atividade das raízes da pupunha pode estar ocorrendo na estação seca, quando também ocorre aumento de alguns parâmetros de crescimento da parte aérea. Moraes (2002) verificou aumento do perfilhamento e emissão de folhas em função do aumento da radiação solar nas condições climáticas da Amazônia Central. Devido à nebulosidade existente na estação chuvosa, o índice de radiação solar nessa região é maior na estação seca (Embrapa, 1997). Os dados de Moraes (2002) demonstraram que há uma estreita relação entre produção de pupunha e o índice de radiação solar. Além disso, o manejo da cultura da pupunha pode estar alterando a sazonalidade "natural" da colonização micorrízica da espécie. Em razão da colheita de palmito, é realizado o manejo de corte a cada quatro meses.

Tanto no cupuaçu quanto na pupunha, a colonização micorrízica foi maior nos monocultivos independente da época de coleta (Figura 7). No monocultivo, a taxa de colonização foi $28 \%$ e $21 \%$ superior aos valores observados no SAF, para o cupuaçu e pupunha respectivamente. A colonização micorrízica da pupunha apresentou correlação positiva com o P disponível $(\mathrm{p}<0,05)$. No cupuaçu a colonização micorrízica foi positivamente correlacionada com a soma de bases e a saturação por bases, e negativamente com a CTC, a acidez potencial e o Alumínio trocável (Figura 8).

Esses resultados demonstram que o manejo pode alterar o estabelecimento e extensão da simbiose micorrízica, como já constatado em outros estudos, com outras espécies de plantas (Feldmann et al., 2002; Fernandes \& Siqueira, 1989; Galvez et al., 2001; Kabir et al., 1997; Miller \& Jackson, 1998) e mais especificamente na pupunha (Bovi et al., 1998).

A identificação de fatores determinantes do efeito do sistema de manejo sobre a microbiota edáfica tem se revelado uma tarefa de difícil execução, em virtude da complexidade existente, mesmo em ecossistemas agrícolas. Quando se avalia sistemas de manejo diferentes, muitos são os fatores que podem estar atuando. Isso porque sistemas de manejo envolvem desde o preparo do solo, manejo nutricional, espaçamento e distribuição das plantas, controle de pragas, doenças e vegetação espontânea, etc. 


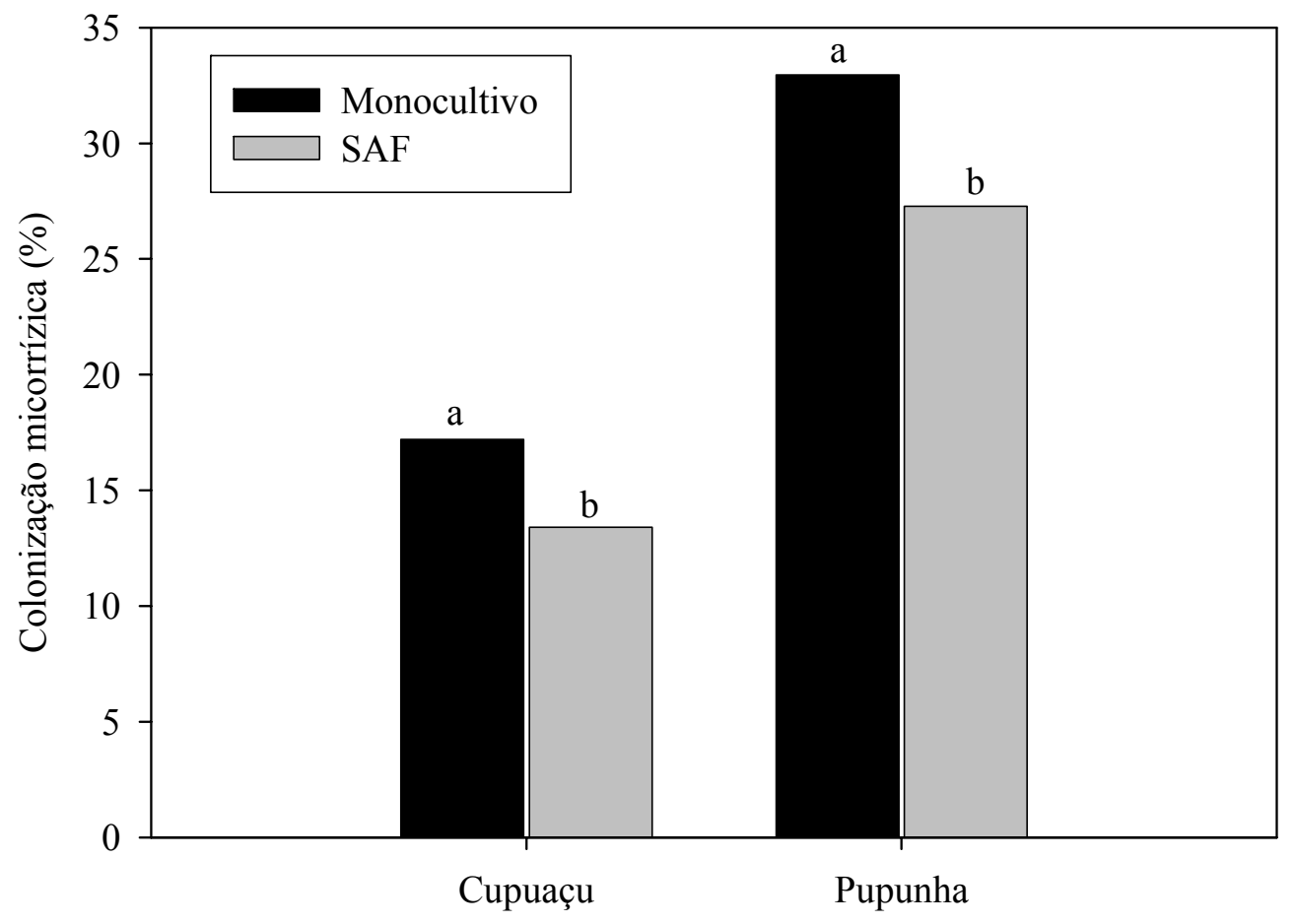

Figura 7 - Colonização micorrízica de cupuaçu e pupunha nos monocultivos e no sistema agroflorestal (SAF). Médias das duas coletas. Numa mesma espécie, médias com mesma letra não diferem entre si (Teste $t, p<5 \%$ ) 


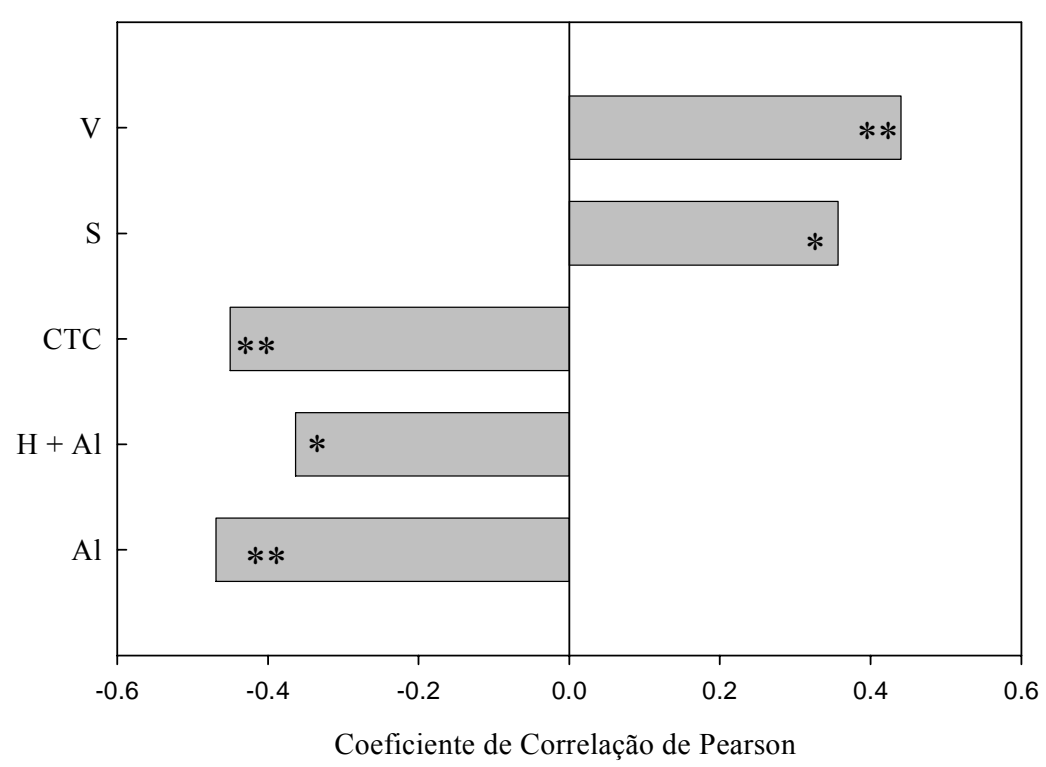

Figura 8 - Coeficientes de correlação de Pearson da colonização micorrízica de cupuaçu com os parâmetros de solo saturação por bases (S), Alumínio trocável $(\mathrm{Al})$, acidez potencial $(\mathrm{H}+\mathrm{Al})$ e capacidade de troca catiônica (CTC.). $*(\mathrm{p}<0,05)$ e ** $(\mathrm{p}<0.01)$

Nesse trabalho os sistemas de manejo avaliados são contrastantes sob dois aspectos principais: a composição, distribuição e espaçamento das espécies de plantas e o manejo nutricional. Algumas inferências podem ser realizadas a partir dessas características do conhecimento sobre a simbiose micorrízica arbuscular. Os monocultivos estudados caracterizam-se por sistemas onde o cupuaçu e a pupunha possuem maior disponibilidade de luz do que no SAF, como pode ser inferido pela distribuição das plantas (Figura 1) e verificado para a pupunha por Moraes (2002). Em condições controladas a intensidade luminosa tem apresentado efeito regulador sobre a colonização micorrízica. Aumentos da disponibilidade de luz tem resultado em maiores taxas de colonização (Smith \& Read, 1997). No entanto, com base nos dados desse estudo, não é possível concluir se esse seria o mecanismo mais importante no efeito positivo que o sistema de monocultivo apresentou sobre a colonização da pupunha e do cupuaçu. 
Por outro lado, fatores edáficos têm sido exaustivamente discutidos como reguladores da simbiose micorrízica arbuscular (Moreira \& Siqueira, 2002; Silveira, 1998; Smith \& Read, 1997). Entre esses fatores, a disponibilidade de P no solo tem sido reportada como um dos fatores mais comuns. Embora altos teores de $\mathrm{P}$ disponíveis reduzam a colonização micorrízica, doses intermediárias podem exercer efeito positivo (Moreira \& Siqueira, 2002; Smith \& Read, 1997). No caso da pupunha, algumas evidências apontam para o envolvimento do $\mathrm{P}$ na determinação da maior taxa de colonização observada no monocultivo: há uma maior disponibilidade de $\mathrm{P}$ no monocultivo quando comparado ao SAF e há uma correlação positiva entre colonização micorrízica arbuscular e P disponível no solo. A regulação da colonização micorrízica arbuscular intermediada pelo P disponível no solo sob a pupunha é corroborado pelos resultados obtidos por Bovi et al. (1998). Esses autores verificaram, em estudo realizado com pupunha em condições de campo, que a colonização micorrízica foi favorecida em doses intermediárias de $\mathrm{P}$, sendo que esse efeito esteve associado à disponibilidade de $\mathrm{N}$. Aumento da colonização micorrízica devido a adubação também já foi verificada por Feldmann et al. (2002) em seringueira nas mesmas condições edafo climáticas do presente estudo.

Em relação ao cupuaçu, a maior taxa de colonização micorrízica observada no monocultivo parece não estar relacionada à disponibilidade de $\mathrm{P}$. Embora haja diferença nos níveis de $\mathrm{P}$ no solo sob o cupuaçu nos dois sistemas de manejo, não foi observada, no cupuaçu, correlação significativa entre colonização micorrízica e este parâmetro de solo. As evidências apontam para o envolvimento da soma de bases e da saturação por bases no complexo de troca na determinação do efeito do monocultivo de cupuaçu. A soma de bases e saturação por bases do complexo de troca do solo foram maiores sob cupuaçu cultivado em monocultivo comparado ao cupuaçu em SAF (Tabela 1), e foram estes os parâmetros de solo que apresentaram correlação positiva significativa com a taxa de colonização micorrízica do cupuaçu (Figura 7) .

A colonização de cupuaçu apresentou correlações significativas com vários parâmetros de solo que sofrem influência da calagem, tais como acidez potencial, soma de bases e saturação por bases e Al trocável (Figura 7). Esta resposta encontra suporte 
no efeito que a calagem exerce sobre a colonização micorrízica observada por outros autores (Lambais \& Cardoso, 1988; Saggin-Jr \& Siqueira, 1996).

\subsection{Densidade de Esporos}

A densidade total de esporos de fungos MA sob o cupuaçu não teve variação significativa nos dois sistemas de manejo nas duas estações (dados não apresentados), segundo a análise de variância. Sob a pupunha, a densidade total de esporos de fungos MA não sofreu efeito dos fatores sistema de manejo e época do ano, mas houve efeito significativo da interação entre esses dois fatores $(p<0,05)$, como se pode observar na Figura 9.

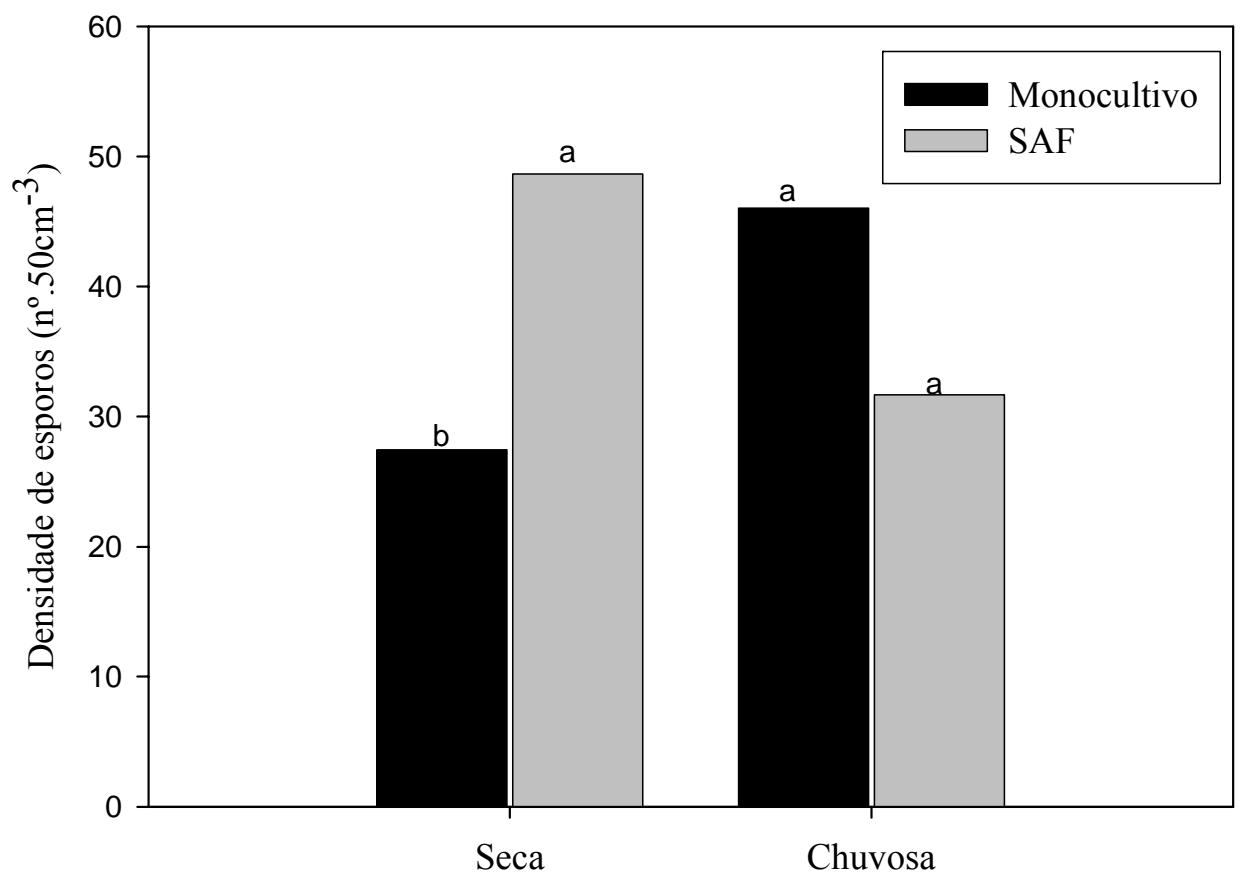

Figura 9 - Densidade de esporos na rizosfera de pupunha em monocultivo e em sistema agroflorestal (SAF) nas estações seca e chuvosa. Para uma mesma estação, médias com mesma letra não diferem entre si (Teste $\mathrm{t}, \mathrm{p}<5 \%$ ) 


\subsection{Ocorrência de Fungos MA}

Os dados de ocorrência de espécies serão apresentados e discutidos em relação à ocorrência total, freqüência e abundância.

\subsubsection{Ocorrência Total de Espécies}

Foram observados 66 morfotipos de esporos nas diferentes áreas e nas duas coletas realizadas, dos quais 28 foram identificados no nível de espécie, 29 no nível de gênero e sete não tiveram sua identidade taxonômica definida. Das 66 espécies, 49 foram observadas na estação seca e 46 na chuvosa. Na estação seca verificou-se a ocorrência de espécies de todos os gêneros de fungos MA, à exceção de Gigaspora (Tabela 2).

Os gêneros Glomus e Acaulospora tiveram o maior número de espécies e foram os mais comuns nos dois sistemas, tanto no cupuaçu quanto na pupunha e nas entrelinhas. Esses gêneros ocorreram em todas as amostras avaliadas nas duas estações. Apesar de ser observada a ocorrência de espécies dos gêneros Archeospora, Entrophospora, Paraglomus e Scutellospora, o número de espécies desses gêneros foi baixo e essas espécies apresentaram freqüência de ocorrência baixa. Na estação seca, quando esses gêneros foram mais freqüentes, observou-se as seguintes freqüências de ocorrência no total de amostras: Entrophospora, 22\%; Archaeospora, 6\%; Paraglomus, $25 \%$ e Scutellospora, 5\%. Já na estação chuvosa, esses valores para os gêneros Paraglomus e Scutellospora foram de 13\% e 2\%, respectivamente.

Algumas mudanças na ocorrência dos gêneros e no número total de espécies foram observadas entre a estação seca e a chuvosa. Na estação chuvosa não foi observada a presença de esporos de espécies dos gêneros Archaeospora e Entrophospora. Houve também uma redução do número de espécies do gênero Acaulospora em todas as áreas. 
Tabela 2. Espécies de fungos MA por gênero na entrelinha (Ent), sob o cupuaçu (Cup) e a pupunha (Pup) nos monocultivos e no sistema agroflorestal (SAF) nas estações seca e chuvosa

\begin{tabular}{|c|c|c|c|c|c|c|c|}
\hline \multirow[b]{2}{*}{ Gêneros } & \multicolumn{2}{|c|}{ Monocultivo } & \multicolumn{2}{|c|}{ Monocultivo } & \multicolumn{3}{|c|}{ SAF } \\
\hline & Cup & Ent & Pup & Ent & Cup & Pup & Ent \\
\hline & \multicolumn{7}{|c|}{ Estação Seca } \\
\hline Acaulospora & 10 & 8 & 8 & 10 & 10 & 9 & 8 \\
\hline Archaeospora & - & - & - & - & 1 & 1 & 1 \\
\hline Entrophospora & 1 & - & 1 & - & 2 & 1 & - \\
\hline Glomus & 14 & 18 & 13 & 12 & 12 & 10 & 14 \\
\hline Paraglomus & 2 & - & 1 & 1 & 2 & 1 & 2 \\
\hline Scutellospora & - & 2 & - & - & - & 1 & - \\
\hline Não Identificados & 2 & 1 & - & 1 & 2 & 1 & - \\
\hline \multirow[t]{2}{*}{ Total de Espécies } & 29 & 29 & 23 & 24 & 29 & 24 & 25 \\
\hline & \multicolumn{7}{|c|}{ Estação Chuvosa } \\
\hline Acaulospora & 8 & 6 & 7 & 7 & 6 & 6 & 6 \\
\hline Glomus & 17 & 16 & 16 & 12 & 15 & 10 & 16 \\
\hline Paraglomus & 1 & 1 & - & 1 & 1 & 1 & 1 \\
\hline Scutellospora & - & 1 & - & - & - & - & - \\
\hline Não Identificados & 4 & 3 & - & 2 & - & 1 & 1 \\
\hline Total de Espécies & 30 & 27 & 23 & 22 & 22 & 18 & 24 \\
\hline
\end{tabular}

Também se verificou uma redução do número de espécies sob o cupuaçu e a pupunha quando cultivados no SAF na avaliação realizada na estação chuvosa, não ocorrendo o mesmo nos sistemas de monocultivos. Não ocorreram grandes variações do número total de espécies nos solos sob a pupunha, o cupuaçu e a entrelinha dentro e entre os sistemas de manejo estudados. No entanto, na estação chuvosa, sob a pupunha cultivada no SAF, ocorreram apenas $60 \%$ do número de espécies observadas sob o cupuaçu em monocultivo.

Considerando os estudos de ocorrência de fungos MA já realizados no Brasil, o número total de espécies fúngicas observados em cada espécie vegetal por estação é similar aos valores encontrados em café no sul de Minas Gerais (Fernandes \& Siqueira, 1989) e no estado de São Paulo (Lopes et al., 1978), em citrus sob manejo orgânico no 
estado de São Paulo (França, 2004) e sob manejo orgânico e convencional no estado do Rio Grande do Sul (Focchi et al., 2004), em Araucaria angustifolia no estado de São Paulo (Moreira-Souza et al., 2003) e no estado de Santa Catarina (Albuquerque, 2003), em seringueira no estado do Amazonas (Feldmann et al., 2002).

Contudo, ressalta-se que há diferenças importantes em relação à escala em que esses estudos foram realizados. Fernandes \& Siqueira (1989) e Lopes et al. (1983) tomaram amostras em áreas de maior abrangência, numa escala de centenas de quilômetros, enquanto que os demais estudos citados foram realizados na escala de poucos quilômetros. Considerando que as parcelas avaliadas no presente trabalho estendem-se numa área de cerca de 13ha, o número de espécies aqui observado mostrase ainda mais relevante. Na avaliação da ocorrência de espécies de fungos MA as grandes diferenças de escala constitui em dificuldade de comparação entre diferentes estudos.

Em relação aos estudos realizados em outras regiões dos trópicos úmidos, o número total de espécies deste estudo foi tão elevado quanto aqueles observados em plantações de Terminalia spp. na Costa do Marfim, onde Wilson et al. (1994) encontraram 41 espécies de fungos MA, numa única época de coleta. E na Costa Rica em áreas de floresta e pastagens, Johnson \& Wedin (1997) encontraram 29 espécies. Esses dados indicam que há uma diversidade elevada de espécies de fungos MA em áreas da zona tropical úmida.

A grande predominância dos gêneros Glomus e Acaulospora nesse trabalho confirma o amplo padrão de distribuição desses gêneros observados por outros autores na zona tropical, tanto em ecossistemas naturais como em agrossistemas (Cuenca \& Meneses, 1996; Feldmann et al., 2002; Fernandes \& Siqueira, 1989; França, 2004; Johnson \& Wedin, 1997; Wilson et al., 1994; Zhao et al., 2001). Esse padrão de distribuição seria um indicativo de que esses gêneros apresentam uma alta capacidade adaptativa a faixas amplas de condições ambientais. Fernandes (1987) comprovou essa alta capacidade adaptativa de várias espécies dos gêneros Glomus e Acaulospora em relação a diversos parâmetros de solo, dentre os quais se destacam o pH e os teores trocáveis de $\mathrm{Ca}+\mathrm{Mg}$ e de $\mathrm{Al}$. 
Outro aspecto aqui observado é a reduzida ocorrência do gênero Scutellospora e a ausência do gênero Gigaspora, representantes da família Gigasporacea, nas amostras avaliadas nas duas estações do ano. A família Gigasporacea tem apresentado baixa freqüência nos estudos de ocorrência de espécies de fungos MA nos trópicos úmidos (Johnson \& Wedin, 1997;Wilson et al. , 1994; Zhao et al., 2001). Espécies dessa família têm apresentado ocorrência em faixas de $\mathrm{pH}$ mais restrita. Fernandes (1987) e Sieverding (1991) mencionam pH acima de cinco como a faixa de ocorrência de algumas espécies representantes dessa família. Isso talvez explique a baixa freqüência de ocorrência de espécies da família Gigasporaceae nos trópicos úmidos e mais especificamente nas áreas do presente trabalho, visto que os solos dos trópicos úmidos são caracterizados por serem ácidos (Sanches, 1981). O pH do solo das áreas avaliadas nesse trabalho encontrou-se em torno de quatro (Tabela 2), abaixo portanto da faixa de $\mathrm{pH}$ acima mencionada.

\subsubsection{Freqüência de Ocorrência}

A partir da freqüência de ocorrência dos esporos de fungos MA observada nas estações seca e chuvosa nas nove repetições avaliadas estabeleceu-se as seguintes classes : raros (1-2), ocasionais (3-4), freqüentes (5-6) e comuns (7-9). Na Figura 10 está resumida a distribuição do número de espécies de fungos MA por classes de freqüência, observadas sob o cupuaçu, sob a pupunha e nas entrelinhas nos sistemas de monocultivos e SAF. Alguns padrões são bem generalizados entre as espécies de plantas e sistemas. O número de espécies raras em todas as comunidades foi maior do que as demais classes nas duas estações do ano, à exceção da comunidade sob a pupunha na estação chuvosa. O número de espécies consideradas comuns foi relativamente pequeno, considerando o total de espécies observadas nessas comunidades. Na estação chuvosa houve uma redução das espécies raras observadas nas comunidades do SAF e no monocultivo de pupunha, fato que não ocorreu no monocultivo de cupuaçu. Também nessa estação, apenas uma espécie foi considerada comum sob o cupuaçu e na entrelinha no SAF: G. sp. 10 e G. sp.1, respectivamente. 
Nas Tabelas 3 e 4 encontram-se as freqüências relativas das espécies observadas na estação seca e chuvosa, respectivamente. As espécies consideradas raras na maioria dos tratamentos não serão consideradas na discussão dos dados de frequência.

Nas duas estações, as espécies A. mellea, A. aff. mellea e G. macrocarpum foram classificadas como freqüentes ou comuns na duas espécies em qualquer dos sistemas de manejo avaliados. G. etunicatum também apresentou essa alta frequência de ocorrência, à exceção do monocultivo de pupunha durante a estação chuvosa. Isto indica uma alta capacidade de adaptação dessas espécies aos gradientes das condições ambientais existentes na área experimental. Amplo espectro de ocorrência A. mellea e G. etunicatum também foi observado em outros estudos. Em agrossistemas de cafeeiro na região Sudeste, Saggin-Junior \& Siqueira (1996) revisando vários estudos destacaram a existentes na área experimental. Amplo espectro de ocorrência de A. mellea e G. etunicatum também foi observado em outros estudos. Em agrossistemas de cafeeiro na região Sudeste, Saggin-Junior \& Siqueira (1996), revisando vários estudos, destacaram a presença dessas espécies entre as de freqüência de ocorrência alta, com valores acima de $20 \%$. 

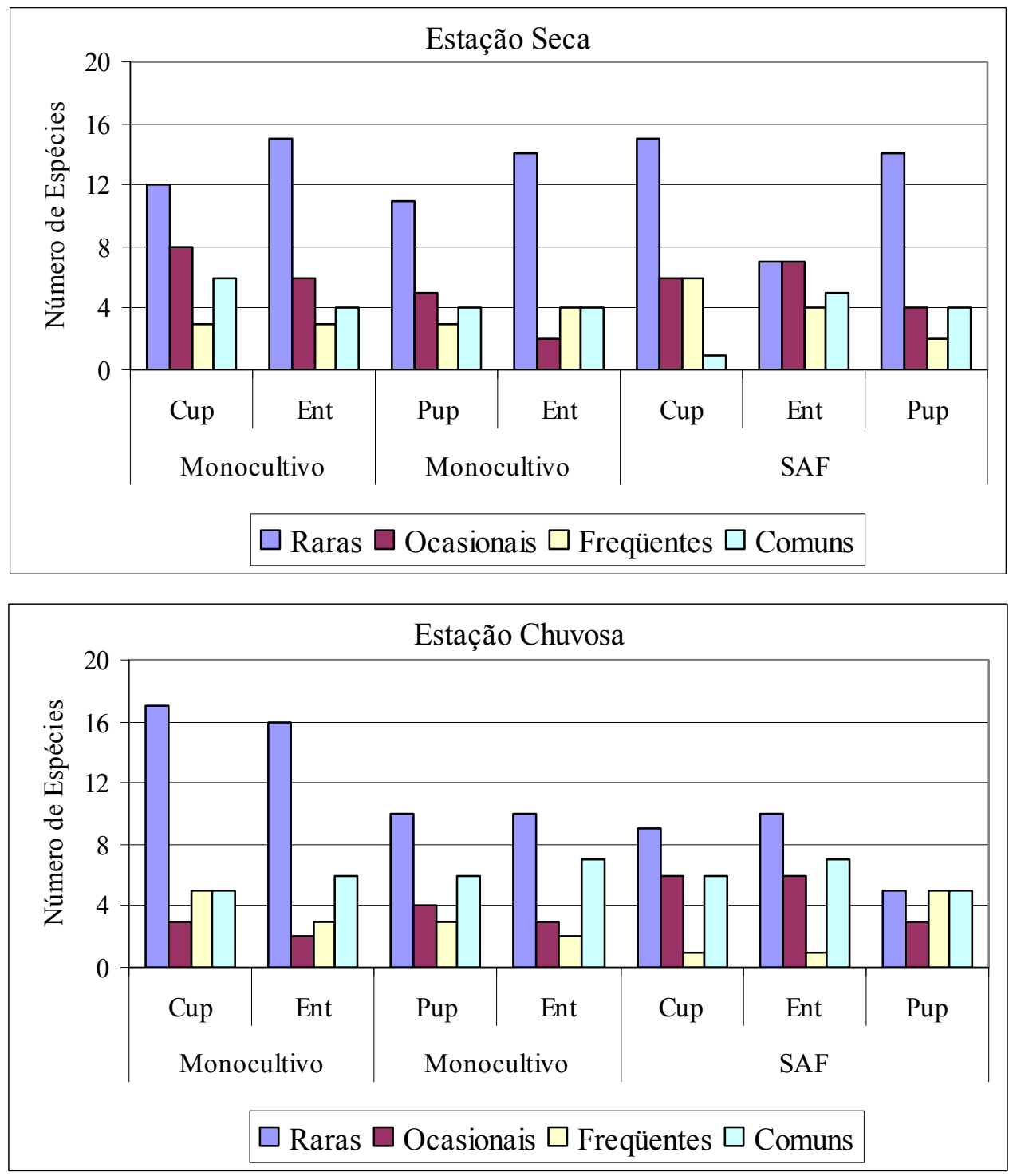

Figura 10 - Ocorrência de classes de freqüência de espécies de fungos MA sob o Cupuaçu (Cup), a Pupunha (Pup) e entrelinhas nos monocultivos e no SAF, nas estações seca e chuvosa. $n=9$ 
Tabela 3. Freqüência relativa da ocorrência de espécies de FMA sob o cupuaçu (Cup), a pupunha (Pup) e entrelinhas (Ent), nos monocultivos e sistema agroflorestal (SAF) na estação seca

\begin{tabular}{|c|c|c|c|c|c|c|c|}
\hline \multirow[t]{2}{*}{ Espécies } & \multicolumn{2}{|c|}{ Monocultivo } & \multicolumn{2}{|c|}{ Monocultivo } & \multicolumn{3}{|c|}{ SAF } \\
\hline & Cup & Ent & Pup & Ent & Cup & Ent & Pup \\
\hline Acaulospora foveata & 33 & 11 & 44 & 11 & 22 & - & - \\
\hline Archaeospora gerdemannii & - & - & - & - & 11 & 11 & 22 \\
\hline Acaulospora laevis & - & - & - & - & 22 & 11 & - \\
\hline Acaulospora mellea & 100 & 67 & 89 & 67 & 67 & 89 & 100 \\
\hline Acaulospora aff. mellea & 100 & 100 & 78 & 89 & 89 & 100 & 100 \\
\hline Acaulospora morrowiae & 78 & 44 & 56 & 67 & 56 & 100 & 67 \\
\hline Acaulospora rehmii & 44 & 44 & 11 & 11 & 33 & 78 & 22 \\
\hline Acaulospora scrobiculata & 44 & 22 & 56 & 78 & 33 & 33 & 11 \\
\hline Acaulospora sp. 1 & 33 & 11 & - & 22 & 11 & - & 11 \\
\hline Acaulospora sp. 2 & - & - & - & - & - & - & 11 \\
\hline Acaulospora sp. 3 & 56 & 44 & 78 & 78 & 33 & 33 & 33 \\
\hline Acaulospora sp. 4 & 11 & - & - & - & - & - & - \\
\hline Acaulospora sp. 5 & - & - & - & 11 & - & - & - \\
\hline Acaulospora spinosa & 33 & - & 22 & 22 & 22 & 22 & 11 \\
\hline Entrophospora colombiana & 22 & - & 44 & - & 44 & - & 44 \\
\hline Entrophospora infrequens & - & - & - & - & 11 & - & - \\
\hline Glomus caledonium & - & - & 11 & - & - & - & - \\
\hline Glomus clarum & 11 & 11 & 11 & 44 & - & 33 & 22 \\
\hline Glomus diaphanum & 33 & 33 & 11 & 11 & 22 & 67 & 22 \\
\hline Glomus etunicatum & 100 & 78 & 33 & 33 & 56 & 67 & 78 \\
\hline Glomus fasciculatum & 56 & 67 & 22 & 11 & 33 & 11 & 11 \\
\hline Glomus geosporum & - & 11 & - & - & - & - & - \\
\hline Glomus invermaium & 33 & 67 & 44 & 67 & 22 & 33 & 33 \\
\hline Glomus macrocarpum & 78 & 100 & 89 & 100 & 67 & 89 & 100 \\
\hline Glomus microagregatum & 67 & 44 & 33 & 22 & 67 & 56 & 22 \\
\hline Glomus microcarpum & - & 11 & - & 11 & - & - & - \\
\hline Glomus sinuosum & - & - & - & 11 & - & 22 & - \\
\hline Glomus viscosum & - & - & 11 & - & - & - & - \\
\hline Glomus sp. 1 & 89 & 33 & - & - & 56 & 44 & 44 \\
\hline Glomus sp. 2 & - & - & - & - & 22 & - & - \\
\hline Glomus sp. 3 & - & - & - & - & 44 & 11 & - \\
\hline Glomus sp. 4 & - & - & - & - & - & 11 & - \\
\hline Glomus sp. 5 & 22 & 11 & - & - & 11 & - & - \\
\hline Glomus sp. 6 & 11 & - & - & - & - & - & - \\
\hline Glomus sp. 7 & - & 11 & 11 & - & - & - & - \\
\hline Glomus sp. 8 & 11 & 11 & - & 11 & - & 11 & 11 \\
\hline Glomus sp. 9 & - & 22 & - & - & - & - & - \\
\hline Glomus sp 10 ('ovo frito’) & 33 & 78 & 56 & 67 & 56 & 44 & 56 \\
\hline Glomus sp. 11 & 11 & 11 & 11 & - & 11 & 22 & - \\
\hline Glomus sp. 12 & - & 11 & - & - & - & - & - \\
\hline Glomus sp. 13 & - & 11 & - & - & - & - & - \\
\hline Glomus sp. 14 & 11 & - & 11 & 11 & - & - & - \\
\hline Paraglomus brasilianum & 22 & - & 11 & - & 11 & 56 & 11 \\
\hline Paraglomus occultum & 22 & - & - & 11 & 11 & 44 & - \\
\hline Scutellospora pachycaulus & - & 11 & - & - & - & - & - \\
\hline Scutellospora weresubiae & - & 11 & - & - & - & - & 11 \\
\hline Nid1 & - & - & - & - & 11 & - & - \\
\hline Nid2 & 11 & - & - & - & - & - & - \\
\hline Nid3 & 11 & 11 & - & 11 & - & - & - \\
\hline Nid4 & - & - & - & - & 11 & - & 11 \\
\hline
\end{tabular}


Tabela 4. Freqüência relativa da ocorrência de espécies de FMA na entrelinha (Ent), no cupuaçu (Cup) e na pupunha (Pup) nos monocultivos e sistema agroflorestal (SAF) na estação chuvosa

\begin{tabular}{|c|c|c|c|c|c|c|c|}
\hline \multirow{2}{*}{ Espécies } & \multicolumn{2}{|c|}{ Monocultivo } & \multicolumn{2}{|c|}{ Monocultivo } & \multicolumn{3}{|c|}{ SAF } \\
\hline & Cup & Ent & Pup & Ent & Cup & Ent & Pup \\
\hline Acaulospora foveata & 22 & - & 11 & 11 & 22 & - & 11 \\
\hline Acaulospora mellea & 100 & 67 & 67 & 89 & 100 & 100 & 67 \\
\hline Acaulospora aff. mellea & 78 & 67 & 78 & 78 & 100 & 78 & 89 \\
\hline Acaulospora morrowiae & 67 & 33 & 44 & 44 & 78 & 78 & 67 \\
\hline Acaulospora rehmii & 11 & - & - & 11 & - & - & - \\
\hline Acaulospora scrobiculata & 89 & 44 & 44 & 56 & 44 & 44 & 33 \\
\hline Acaulospora sp. 3 & 100 & 44 & 78 & 44 & 78 & 89 & 78 \\
\hline Acaulospora sp. 6 & - & - & - & - & - & 11 & - \\
\hline Acaulospora spinosa & 22 & 11 & 11 & - & - & - & - \\
\hline Glomus clarum & 22 & 11 & 44 & 11 & - & 33 & 11 \\
\hline Glomus diaphanun & 11 & - & 22 & 22 & 22 & 22 & - \\
\hline Glomus etunicatum & 67 & 89 & 100 & 78 & 44 & 78 & 78 \\
\hline Glomus fasciculatum (sensu & & & & & & & \\
\hline Schenck \& Perez, 1987) & - & - & - & - & - & - & 11 \\
\hline Glomus fasciculatum & 44 & 78 & 33 & 67 & 33 & 11 & 56 \\
\hline Glomus geosporum & - & 11 & 11 & - & - & - & - \\
\hline Glomus invermaium & 67 & 67 & 67 & 89 & 44 & 33 & 56 \\
\hline Glomus macrocarpum & 89 & 100 & 100 & 100 & 100 & 89 & 78 \\
\hline Glomus microagregatum & 44 & 78 & 56 & 56 & 22 & 44 & 78 \\
\hline Glomus spurcum & - & 11 & - & 11 & 11 & - & - \\
\hline Glomus tortuosum & - & - & 11 & - & - & - & - \\
\hline Glomus sp. 1 & 78 & 89 & 22 & - & 78 & 56 & 33 \\
\hline Glomus sp. 3 & 22 & 22 & 11 & - & - & 11 & - \\
\hline Glomus sp. 5 & 11 & - & 22 & 11 & 11 & - & - \\
\hline Glomus sp. 8 & 11 & - & 11 & - & 44 & 11 & - \\
\hline Glomus sp. 10 ('ovo frito') & 67 & 78 & 100 & 100 & 67 & 78 & 56 \\
\hline Glomus sp. 11 & 33 & 22 & 100 & 100 & 44 & 44 & 44 \\
\hline Glomus sp. 12 & 11 & 22 & - & - & 11 & 33 & - \\
\hline Glomus sp. 15 & - & - & - & - & - & 22 & - \\
\hline Glomus sp. 16 & 11 & - & - & - & 11 & 11 & - \\
\hline Glomus sp. 17 & - & - & - & - & - & 11 & - \\
\hline Glomus sp. 18 & - & - & - & - & 11 & - & - \\
\hline Glomus sp. 19 & - & - & 11 & - & - & - & - \\
\hline Glomus sp. 20 & - & 11 & - & - & - & - & - \\
\hline Glomus sp. 21 & 11 & - & - & - & - & - & - \\
\hline Glomus sp. 22 & 11 & - & - & - & - & - & - \\
\hline Glomus sp. 23 & - & 11 & - & - & - & - & - \\
\hline Glomus sp. 24 & - & 11 & - & - & - & - & - \\
\hline Glomus sp. 25 & - & - & - & 11 & - & - & - \\
\hline Paraglomus brasilianum & 11 & 22 & - & 11 & 11 & 22 & - \\
\hline Paraglomus occultum & - & - & - & - & - & - & 11 \\
\hline Scutellospora callospora & - & 11 & - & - & - & - & - \\
\hline NID4 & 11 & - & - & - & - & - & 11 \\
\hline NID7 & - & 11 & - & 22 & - & 11 & - \\
\hline NID6 & 11 & 11 & - & 11 & - & - & - \\
\hline NID3 & 22 & 22 & - & - & - & - & - \\
\hline NID5 & 22 & - & - & - & - & - & - \\
\hline
\end{tabular}


As espécies A. morrowiae, G. microagregatum, G. invermaium, A. scrobiculata também estiveram presentes sob o cupuaçu, a pupunha e entrelinhas nos dois sistemas de cultivo, apesar de terem em geral freqüência mais baixa do que as espécies $A$. mellea, A. aff. mellea , G. macrocarpum e G. etunicatum.

De modo geral, as espécies não apresentaram grandes variações de freqüência entre as duas épocas estudadas (Tabela 3 e 4). Exceções foram as espécies G. sp 10 e G. sp 11, que apresentaram maiores freqüências na estação chuvosa.

Nas estações seca e chuvosa ocorreram algumas associações preferenciais entre espécies de fungos MA e o cupuaçu e a pupunha nos dois sistemas de manejo. Na estação seca a espécie $A$. sp 3 teve maior freqüência no monocultivo de pupunha. $\mathrm{O} G$. sp1, G. microagregatum e G. etunicatum estiveram mais associados ao cupuaçu no monocultivo e no SAF. G. fasciculatum esteve mais associado ao cupuaçu em monocultivo. Na estação chuvosa o G. sp1 e A. morrowiae estiveram preferencialmente associado ao cupuaçu nos dois sistemas de manejo, ao passo que para G. sp 11 essa associação preferencial se deu com a pupunha em monocultivo.

As espécies de maior freqüência observadas nesse estudo (A. mellea, G. macrocarpum e G. etunicatum) foram consideradas por Fernandes (1987) como de ocorrência em ampla faixa de condições edáficas, tais como $\mathrm{pH}$ e $\mathrm{P}$ disponível. A distribuição mais indiscriminada dessas espécies indica que elas teriam características de alta plasticidade inerente aos gêneros Glomus e Acaulospora, como anteriormente discutido.

A partir dos dados de frequencia procedeu-se uma análise de agrupamento, cujos dendrogramas referentes as estações seca e chuvosa encontram-se na Figura 11. Tanto na estação seca como na chuvosa pode-se verificar que há a formação de dois grupos bastante distintos. Quando a pupunha cultivada em monocultivo, ela agrupa-se com a sua respectiva entrelinha, destacando-se dos demais locais. 

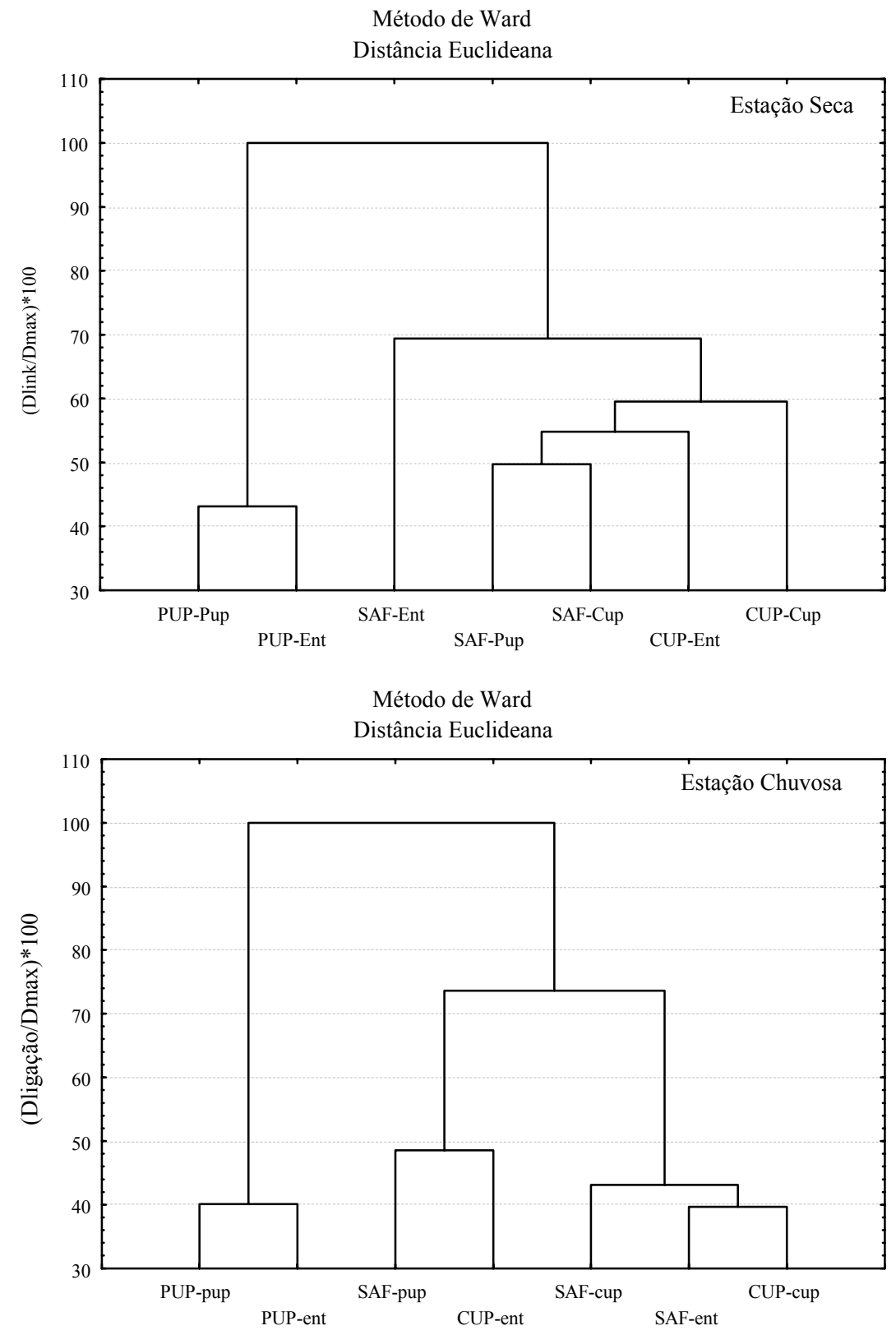

Figura 11 - Dendrogramas de similaridade obtidos pela análise de agrupamento diferenciando os sistemas e espécies estudadas. Baseado na freqüência de ocorrência das espécies de fungos MA observados na entrelinha (Ent), no cupuaçu (Cup) e na pupunha (Pup), nos monocultivos de pupunha (PUP) e Cupuaçu (CUP), e no sistema agroflorestal (SAF) nas estações seca e chuvosa $. \mathrm{n}=9$. 


\subsubsection{Abundância de Esporos das Espécies de Fungos MA}

Nas Tabelas 6 e 7 encontram-se as médias e o desvio padrão da abundância de esporos das diferentes espécies de fungos MA. A abundância de esporo apresentou correlação significativa com a freqüência de ocorrência nas estações seca $\left(r^{2}=0,99 ; p<\right.$ $0,05)$ e chuvosa $\left(\mathrm{r}^{2}=0,60 ; \mathrm{p}<0,05\right)$. Assim, muitas respostas em abundância seguem as tendências descritas para freqüência.

De modo geral, A.mellea, A. aff. mellea e G. macrocarpum estiveram entre as espécies mais abundantes sob o cupuaçu, a pupunha e as entrelinhas nos dois sistemas de manejo.

Os dados de abundância de esporos das diferentes espécies de fungos MA apresentaram uma alta variabilidade, que pode ser comprovada pelos valores elevados dos desvios padrão (Tabelas 5 e 6). Esta variabilidade elevada também foi observada por Carrenho et al. (2001) em estudo realizado em parcelas menores de monocultivo de milho. Isso é um indicativo da elevada variabilidade espacial da distribuição das espécies de fungos MA. Tal fato torna bastante difícil a aplicação de métodos da Estatística clássica. Além disso, resultados recentes têm demonstrado que o padrão de distribuição espacial pode variar entre os gêneros, e que os fatores que determinariam essa distribuição podem mudar em função do ecossistema considerado (Carvalho et al., 2003).

Neste trabalho foram observadas correlações significativas entre a abundância de esporos de algumas espécies e algumas características de solo. Na estação seca destacam-se as correlações entre a abundância de esporos das espécies de fungos MA e as características químicas do solo: A. mellea e CTC $\left(\mathrm{r}^{2}=0,28 ; \mathrm{p}<0,01\right)$; A. scrobiculata e a soma de bases $\left(\mathrm{r}^{2}=0,34 ; \mathrm{p}<0,01\right)$; e $A$. sp 3 e o teor de Al trócavel $\left(\mathrm{r}^{2}=-0,34\right.$; $\mathrm{p}<0,01)$. Já na estação chuvosa observou-se um número bem maior de correlações significativas, como pode ser verificado na Tabela 7. Essa resposta diferenciada entre as estações pode estar relacionada ao balanço dos fatores que determinam a esporulação.

Além das características químicas do solo, outros fatores abióticos podem afetar a esporulação e a ocorrência dos fungos MA. Silveira (1998) e Moreira \& Siqueira (2002) citam entre esse fatores abióticos a temperatura, a intensidade luminosa, a 
precipitação e a umidade do solo. Na estação seca a ocorrência da maioria das espécies de fungos MA sofreu pouca influência das características químicas do solo, podendo ser um indicativo de que outros fatores ambientais, como por exemplo a umidade do solo, possam estar determinando a ocorrência desses fungos.

No que se refere as relações entre a abundância das populações de fungos MA e as características químicas do solo na estação chuvosa (Tabela 7), observa-se que algumas espécies foram positivamente correlacionadas aos teores de bases e negativamente aos teores de Al trocável. Fazem parte deste grupo as espécies $A$. scrobiculata, G. etunicatum e G. invermaium . Noutro extremo de resposta encontra-se a espécie $G$. sp 1 que apresentou correlação positiva tanto com o Al trocável quanto com a acidez potencial $\left(\mathrm{H}^{+}+\mathrm{Al}^{+3}\right)$. Em relação a matéria orgânica, as espécies $G$. etunicatum,G. invermaium e G. macrocarpum apresentaram correlações positivas enquanto que com as espécies $A$. sp 3 e A. morrowiae houve correlação negativa.

Interações entre as populações de fungos MA e caracterícticas químicas de solo avaliadas a partir do estudo de correlação também foram observadas por Carrenho et al.(2001), Carvalho et al. (2003), Cuenca \& Meneses (1995) e Fernandes (1987). Nesses estudos os coeficientes de correlação apesar de serem signficativos raramente tem ultrapassado o valor de 0,60 , sendo comuns valores abaixo de 0,50 como observado no presente trabalho.

Essas interações são indicativos de que há diferenças quanto às características autoecológicas das populações de fungos MA observadas nesse estudo. Contudo, são necessárias observações em gradientes maiores das características químicas do solo, a fim de delinear com mais precisão e consistência tais características.

Por outro lado, podemos verificar que houve interação entre as populações de fungos MA, como pode ser constatado pelo nível de significância dos coeficientes de correlação de Spearman dos dados da estação seca (Tabela 8). Nos trabalhos consultados na literatura sobre dinâmica de comunidades de fungos MA não foi identificado nenhum que considerasse as relações entre as populações de fungos MA que compõem uma comunidade. Segundo Odum (1988) e Ricklefs (1990), a dinâmica de uma comunidade qualquer resulta da ação de fatores sobre a comunidade e da interação entre as 
Tabela 5. Média e desvio padrão da ocorrência $\left(n^{\circ} .50 \mathrm{~cm}^{-3}\right.$ solo) das espécies de fungos MA na entrelinha (Ent), no cupuaçu (Cup) e na pupunha (Pup) nos monocultivos e sistema agroflorestal (SAF), na estação seca

\begin{tabular}{|c|c|c|c|c|c|c|c|c|c|c|c|c|c|c|}
\hline \multirow{3}{*}{ Sistema } & \multicolumn{4}{|c|}{ Monocultivo } & \multicolumn{4}{|c|}{ Monocultivo } & \multicolumn{6}{|c|}{ SAF } \\
\hline & \multicolumn{2}{|c|}{ Cup } & \multicolumn{2}{|c|}{ Ent } & \multicolumn{2}{|c|}{ Pup } & \multicolumn{2}{|c|}{ Ent } & \multicolumn{2}{|c|}{ Cup } & \multicolumn{2}{|c|}{ Ent } & \multicolumn{2}{|c|}{ Pup } \\
\hline & Média & $\overline{\text { Desv }}$ & Média & $\overline{\text { Desv }}$ & Média & $\overline{\text { Desv }}$ & Média & $\overline{\text { Desv }}$ & Média & $\overline{\text { Desv }}$ & Média & $\overline{\text { Desv }}$ & Média & Desv \\
\hline A. mellea & 13,44 & 16,09 & 3,56 & 5,36 & 3,33 & 3,35 & 6,00 & 11,49 & 5,67 & 4,69 & 5,33 & 4,00 & 3,78 & 1,92 \\
\hline A.aff. mellea & 78,11 & 183,01 & 3,33 & 2,92 & 6,67 & 8,66 & 11,11 & 10,52 & 18,67 & 14,75 & 11,44 & 12,56 & 9,33 & 9,10 \\
\hline A. morrowiae & 6,11 & 11,92 & 0,67 & 1,00 & 1,00 & 1,32 & 2,67 & 3,50 & 1,33 & 1,73 & 3,44 & 3,78 & 7,00 & 13,19 \\
\hline A. rehmii & 24,56 & 60,99 & 0,67 & 1,00 & 0,22 & 0,67 & 0,11 & 0,33 & 1,11 & 1,76 & 4,56 & 6,62 & 0,44 & 1,01 \\
\hline A. scrobiculata & 1,67 & 3,28 & 0,44 & 0,88 & 1,00 & 1,32 & 3,33 & 3,12 & 0,33 & 0,50 & 1,78 & 3,96 & 0,11 & 0,33 \\
\hline A. sp1 & 5,22 & 10,15 & 0,11 & 0,33 & - & - & 0,22 & 0,44 & 0,11 & 0,33 & - & - & 0,33 & 1,00 \\
\hline A. sp3 & 12,78 & 21,60 & 1,33 & 1,94 & 1,44 & 1,24 & 6,56 & 11,23 & 1,89 & 3,95 & 2,00 & 3,46 & 0,78 & 1,39 \\
\hline A spinosa & 1,44 & 2,40 & - & - & 0,44 & 1,01 & 0,22 & 0,44 & 0,22 & 0,44 & 0,33 & 0,71 & 0,11 & 0,33 \\
\hline E. colombiana & 1,89 & 4,96 & - & - & 0,44 & 0,53 & - & - & 3,56 & 5,94 & - & - & 5,11 & 6,95 \\
\hline G. clarum & 0,22 & 0,67 & 0,22 & 0,67 & 0,22 & 0,67 & 1,33 & 1,87 & - & - & 0,67 & 1,32 & 0,33 & 0,71 \\
\hline G. diaphanum & 24,25 & 66,98 & 1,11 & 1,76 & 0,11 & 0,33 & 0,33 & 1,00 & 0,22 & 0,44 & 19,44 & 49,49 & 12,00 & 35,26 \\
\hline G. etunicatum & 7,22 & 14,23 & 4,56 & 4,16 & 0,44 & 0,73 & 0,67 & 1,12 & 2,56 & 3,81 & 1,89 & 1,69 & 3,22 & 3,38 \\
\hline G. fasciculatum & 6,78 & 13,35 & 3,44 & 5,79 & 0,44 & 1,01 & 0,11 & 0,33 & 0,67 & 1,12 & 0,11 & 0,33 & 0,11 & 0,33 \\
\hline G. invermaium & 2,44 & 5,00 & 2,78 & 3,27 & 0,44 & 0,53 & 1,89 & 2,26 & 1,89 & 4,96 & 0,89 & 1,69 & 2,00 & 3,16 \\
\hline G. macrocarpum & 16,67 & 32,34 & 32,22 & 44,64 & 4,33 & 4,15 & 10,33 & 6,48 & 9,56 & 9,59 & 5,56 & 8,56 & 10,67 & 9,17 \\
\hline G. microagregatum & 7,11 & 12,19 & 3,11 & 4,11 & 1,67 & 2,83 & 0,67 & 1,66 & 5,11 & 7,75 & 6,11 & 10,43 & 1,44 & 3,97 \\
\hline G. sp1 & 9,11 & 12,22 & 1,11 & 1,83 & - & - & - & - & 3,00 & 7,52 & 1,78 & 2,99 & 1,44 & 2,65 \\
\hline G. sp3 & - & - & - & - & - & - & - & - & 1,67 & 2,40 & 0,33 & 1,00 & - & - \\
\hline G. sp6 & 0,11 & 0,33 & - & - & - & - & - & - & - & - & - & - & - & - \\
\hline G. ovofrito & 1,11 & 2,32 & 2,56 & 3,40 & 1,44 & 1,74 & 6,89 & 11,33 & 3,33 & 6,42 & 1,78 & 2,77 & 1,56 & 2,01 \\
\hline P. brasilianum & 5,22 & 14,93 & - & - & 1,33 & 4,00 & - & - & 3,78 & 11,33 & 4,22 & 6,59 & 0,11 & 0,33 \\
\hline P. occultum & 0,78 & 1,99 & - & - & - & - & 0,11 & 0,33 & 0,22 & 0,67 & 1,33 & 2,92 & - & - \\
\hline
\end{tabular}

Foram consideradas apenas as espécies de fungos MA classificadas como ocasionais ou o mais frequentes. 
Tabela 6. Média e desvio padrão da ocorrência $\left(n^{\circ} .50 \mathrm{~cm}^{-3}\right.$ solo) das espécies de fungos MA na entrelinha (Ent), no cupuaçu (Cup) e na pupunha (Pup) nos monocultivos e sistema agroflorestal (SAF), na estação chuvosa

\begin{tabular}{|c|c|c|c|c|c|c|c|c|c|c|c|c|c|c|}
\hline & \multicolumn{4}{|c|}{ Monocultivo } & \multicolumn{4}{|c|}{ Monoculivo } & \multicolumn{6}{|c|}{ SAF } \\
\hline & \multicolumn{2}{|c|}{ Cup } & \multicolumn{2}{|c|}{ Ent } & \multicolumn{2}{|c|}{ Pup } & \multicolumn{2}{|c|}{ Ent } & \multicolumn{2}{|c|}{ Cup } & \multicolumn{2}{|c|}{ Ent } & \multicolumn{2}{|c|}{ Pup } \\
\hline & Média & Desv & Média & Desv & Média & Desv & Média & Desv & Média & Desv & Média & Desv & Média & Desv \\
\hline A. mellea & 5,78 & 5,95 & 1,67 & 2,24 & 2,33 & 2,35 & 2,22 & 1,48 & 3,22 & 2,33 & 2,89 & 1,90 & 2,22 & 3,46 \\
\hline A. aff. mellea & 9,44 & 12,94 & 1,67 & 1,66 & 3,44 & 3,32 & 4,00 & 3,64 & 8,44 & 8,03 & 2,67 & 3,00 & 2,56 & 2,01 \\
\hline A. morrowiae & 2,44 & 2,51 & 1,44 & 2,70 & 1,22 & 2,28 & 0,89 & 1,17 & 2,78 & 4,06 & 1,89 & 1,76 & 1,44 & 1,33 \\
\hline A. scrobiculata & 5,33 & 5,10 & 0,44 & 0,53 & 1,22 & 1,79 & 1,78 & 2,91 & 0,44 & 0,53 & 1,56 & 2,35 & 0,44 & 0,73 \\
\hline A. sp3 & 7,78 & 4,32 & 0,78 & 1,09 & 2,78 & 3,63 & 1,22 & 1,56 & 5,44 & 8,76 & 4,89 & 4,20 & 6,11 & 7,77 \\
\hline G. clarum & 1,00 & 2,35 & 0,11 & 0,33 & 1,11 & 1,76 & 0,11 & 0,33 & - & - & 3,67 & 7,43 & 0,11 & 0,33 \\
\hline G. etunicatum & 2,00 & 1,73 & 5,11 & 3,26 & 7,11 & 6,64 & 3,44 & 3,13 & 1,11 & 1,36 & 1,78 & 1,56 & 1,78 & 1,30 \\
\hline G. fasciculatum & 1,22 & 1,72 & 2,33 & 1,87 & 1,22 & 2,22 & 1,22 & 1,30 & 0,78 & 1,39 & 0,11 & 0,33 & 0,67 & 0,71 \\
\hline G. invermaium & 1,67 & 1,73 & 2,00 & 1,58 & 1,22 & 1,30 & 1,78 & 1,64 & 0,78 & 0,97 & 0,44 & 0,73 & 0,89 & 1,05 \\
\hline G. macrocarpum & 12,11 & 15,45 & 17,44 & 10,09 & 21,56 & 33,66 & 7,11 & 6,05 & 2,78 & 1,92 & 2,89 & 2,67 & 6,11 & 7,49 \\
\hline G. microagregatum & 3,44 & 4,59 & 3,00 & 2,83 & 2,11 & 2,37 & 5,67 & 8,99 & 1,56 & 3,13 & 3,44 & 6,73 & 2,11 & 2,15 \\
\hline G. $\mathrm{sp} 1$ & 4,00 & 3,32 & 4,11 & 2,42 & 0,44 & 1,01 & & & 2,22 & 1,86 & 4,22 & 9,19 & 0,89 & 1,96 \\
\hline G. $\operatorname{sp} 11$ & 1,22 & 2,33 & 0,22 & 0,44 & 4,44 & 3,24 & 4,67 & 4,90 & 0,89 & 1,36 & 1,00 & 1,32 & 1,11 & 1,69 \\
\hline G. $\mathrm{sp} 12$ & 0,44 & 1,33 & 0,67 & 1,32 & - & - & - & - & 0,11 & 0,33 & 0,33 & 0,50 & - & - \\
\hline G. $\operatorname{sp} 8$ & 4,89 & 14,67 & - & - & 0,33 & 1,00 & - & & 2,89 & 4,11 & 0,33 & 1,00 & - & - \\
\hline G. sp 10 ovo frito & 6,67 & 7,94 & 7,89 & 9,01 & 5,56 & 4,93 & 9,33 & 6,00 & 5,22 & 5,80 & 4,67 & 5,70 & 2,22 & 2,91 \\
\hline
\end{tabular}

Foram consideradas apenas as espécies de fungos MA classificadas como ocasionais ou o mais frequentes. 
Tabela 7. Coeficientes de correlação de Spearman entre características químicas do solo e a abundância de esporos de espécies de fungos MA na estação chuvosa

\begin{tabular}{|c|c|c|c|c|c|c|c|c|c|c|c|}
\hline & $\mathrm{pH}$ & $\mathrm{P}$ & $\mathrm{K}+$ & $\mathrm{Ca}^{+2}$ & $\mathrm{Mg}^{+2}$ & $\mathrm{Al}^{+3}$ & $\mathrm{H}^{+}+\mathrm{Al}^{+3}$ & M.O. & CTC & $\mathrm{S}$ & $\mathrm{V}$ \\
\hline A. morrowiae & $-0,16$ & 0,01 & $-0,25$ & $-0,24$ & $-0,27^{*}$ & 0,15 & $-0,07$ & $-0,37 * *$ & $-0,16$ & $-0,24$ & $-0,24$ \\
\hline A. scrobiculata & 0,36 & $0,31^{*}$ & 0,07 & $0,36^{* *}$ & $0,36^{* *}$ & $-0,38 * *$ & 0,03 & 0,18 & 0,18 & $0,40 *$ & $0,42 *$ \\
\hline A. $\mathrm{sp} 3$ & $-0,05$ & 0,21 & $-0,31^{*}$ & $-0,04$ & $-0,23$ & 0,00 & $-0,28 *$ & $-0,34^{*}$ & $-0,26^{*}$ & $-0,10$ & $-0,01$ \\
\hline G. clarum & $0,32 *$ & 0,17 & 0,03 & 0,16 & $0,27 *$ & $-0,20$ & $-0,21$ & 0,06 & $-0,11$ & 0,20 & $0,29 * *$ \\
\hline G. etunicatum & 0,20 & 0,05 & $0,47 * *$ & $0,37 * *$ & $0,40 * *$ & $-0,33 * *$ & 0,21 & $0,32 * *$ & $0,31^{*}$ & $0,39 * *$ & $0,33 * *$ \\
\hline G. invermaium & 0,22 & 0,07 & $0,38 * *$ & $0,34 * *$ & $0,36^{* *}$ & $-0,30$ & 0,28 & $0,36 * *$ & $0,40 * *$ & $0,39 * *$ & $0,27^{*}$ \\
\hline G. macrocarpum & 0,24 & 0,03 & $0,39 * *$ & $0,31 *$ & $0,36^{* *}$ & $-0,24$ & 0,16 & $0,27^{*}$ & 0,23 & $0,34 * *$ & $0,28^{*}$ \\
\hline G. sp 1 & $-0,27^{*}$ & $-0,09$ & $-0,14$ & $-0,04$ & $-0,10$ & $0,27 *$ & $0,28 *$ & $-0,02$ & 0,20 & $-0,05$ & $-0,11$ \\
\hline G. $\mathrm{sp} 11$ & 0,23 & 0,17 & $0,41 * *$ & $0,26^{*}$ & 0,20 & $-0,25$ & 0,03 & 0,10 & 0,07 & 0,22 & 0,19 \\
\hline
\end{tabular}


Tabela 8. Coeficientes de correlação de Spearman entre as abundâncias de esporos das populações de fungos MA nas amostras da estação seca

\begin{tabular}{|c|c|c|c|c|c|c|c|c|c|c|c|c|c|c|c|c|}
\hline & 1 & 2 & 3 & 4 & 5 & 6 & 7 & 8 & 9 & 10 & 11 & 12 & 13 & 14 & 15 & 16 \\
\hline 1. A. mellea & 1 & & & & & & & & & & & & & & & \\
\hline 2. A. aff. mellea & $0,32 * *$ & 1 & & & & & & & & & & & & & & \\
\hline 3. A. morrowiae & 0,11 & $-0,04$ & 1 & & & & & & & & & & & & & \\
\hline 4. A. rehmii & 0,16 & $0,27 *$ & $-0,07$ & 1 & & & & & & & & & & & & \\
\hline 5. A. scrobiculata & 0,13 & 0,09 & $-0,21$ & 0,08 & 1 & & & & & & & & & & & \\
\hline 6. A. sp 1 & 0,19 & 0,19 & $-0,13$ & 0,05 & 0,08 & 1 & & & & & & & & & & \\
\hline 7. A. sp 3 & 0,20 & $0,31^{*}$ & $-0,02$ & 0,10 & 0,17 & $0,41 * *$ & 1 & & & & & & & & & \\
\hline 8. A.spinosa & 0,13 & $0,27 *$ & 0,07 & $0,26^{*}$ & 0,15 & $0,33 * *$ & 0,18 & 1 & & & & & & & & \\
\hline 9. G. diaphanum & 0,18 & $-0,14$ & 0,11 & 0,13 & $-0,14$ & 0,22 & 0,03 & 0,00 & 1 & & & & & & & \\
\hline 10. G. etunicatum & 0,24 & 0,17 & $-0,21$ & $0,26^{*}$ & $-0,04$ & 0,27 & $-0,02$ & 0,11 & $0,27 *$ & 1 & & & & & & \\
\hline 11. G. fasciculatum & 0,16 & 0,16 & $-0,17$ & 0,12 & $-0,08$ & 0,26 & 0,26 & 0,14 & $-0,12$ & 0,20 & 1 & & & & & \\
\hline 12. G. invermaium & $-0,12$ & 0,20 & $-0,18$ & 0,24 & 0,09 & 0,08 & 0,14 & $0,36^{*}$ & $-0,11$ & 0,21 & $0,29 *$ & 1 & & & & \\
\hline 13. G. macrocarpum & 0,13 & 0,24 & $-0,22$ & 0,12 & 0,11 & $-0,06$ & $-0,05$ & 0,08 & $-0,28^{*}$ & $0,46^{* *}$ & $0,32 *$ & $0,46^{* *}$ & 1 & & & \\
\hline 14.G. microagregatum & 0,15 & 0,24 & $-0,11$ & 0,25 & 0,06 & 0,15 & 0,05 & 0,17 & 0,17 & $0,41 * *$ & 0,15 & 0,25 & 0,19 & 1 & & \\
\hline 15.G. sp 1 & $0,34 * *$ & 0,24 & $-0,14$ & $0,31 * *$ & $-0,09$ & 0,20 & $-0,13$ & 0,03 & 0,16 & $0,36^{* *}$ & 0,19 & $-0,21$ & 0,17 & 0,24 & 1 & \\
\hline 16.G. sp 10 'ovo frito' & $0,28 *$ & 0,09 & $-0,13$ & $-0,10$ & $0,33 * *$ & $-0,08$ & 0,06 & $-0,05$ & $-0,16$ & 0,24 & 0,07 & 0,14 & $0,44 * *$ & 0,07 & $-0,10$ & 1 \\
\hline 17.P. brasilianum & 0,16 & 0,09 & $0,28^{*}$ & 0,23 & $-0,08$ & $-0,01$ & 0,07 & $0,26^{*}$ & $0,51^{* *}$ & 0,14 & $-0,07$ & 0,20 & $-0,17$ & 0,16 & 0,03 & $-0,10$ \\
\hline
\end{tabular}


populações que compõem essa comunidade. Sendo assim, no presente trabalho buscouse identificar as interações entre as populações de fungos MA a partir do estudo das correlações entre essas populações.

Ao contrário das interações entre as populações de fungos MA e as carcaterísticas químicas do solo, que foi mais evidente na estação chuvosa, as interações emtre as populações de fungos MA foram mais frequentes na estação seca. Dentre as várias interações que apresentaram coeficientes de correlação signficativo a 0,01 ou 0,05 de probabilidade, na estação seca, destacaram-se algumas por terem apresentado os valores maiores de coeficientes de correlação, além de terem sido observadas também na estação chuvosa. Essas interações foram: G. macrocarpum x G. fasciculatum, G. macrocarpum x G. invermaium e G. macrocarpum x G. sp 10.

\subsection{Diversidade das Comunidades de Fungos MA}

Um dos aspectos mais importantes no estudo de comunidades é a definição da escala ou limites espaciais onde se dão as relações entre as espécies da comunidade considerada. Em comunidades animais e vegetais esses limites são definidos a partir do espaço de movimentação e/ou de dispersão das espécies e no qual se estabelece as relações entre as espécies por recursos e o efeito dos fatores ambientais sobre os componentes da comunidade (Ricklef, 1990).

No presente estudo considerou-se como limite da comunidade de fungos MA os pontos de coletas individuais por planta para efeito de avaliação da diversidade das comunidades desses fungos, em virtude de duas razões. A primeira, em decorrência da íntima relação desses fungos com os hospedeiros, os quais provem os fungos MA das condições essenciais para que completem o seu ciclo de vida e onde a princípio se daria a competição por recursos. E a segunda, pelo desconhecimento do alcance e da importância ecológica dos mecanismos de dispersão dos fungos MA.

O estudo da diversidade das comunidadea, apesar da obviedade que o conceito representa, tem demonstrado ser complexa. A diversidade envolve dois componentes, sendo o primeiro a variedade e o segundo a abundância relativa das espécies. Assim a 
diversidade pode ser medida pelo registro do número de espécies, pela descrição de sua abundância relativa ou por medidas que combinem os dois componentes (Magurran, 1988). Essas medidas são representadas pela riqueza, índices de diversidade, dominânica e equitabilidade (Kennedy \& Smith, 1995). Esses índices apresentam diferenças quanto à sua habilidade discriminante, sensibilidade ao tamanho da amostra, facilidade no cálculo, disseminação de uso e adequação aos modelos de estatística clássica, como destacado por Magurran ( 1988).

Neste trabalho foram escolhidos os índices de Shannon, Pielou e Simpson, como expressão da diversidade, equitabilidade e dominânci, por terem sido os mais encontrado nos trabalhos da literatura relacionados às comunidades de fungos MA.

A densidade total de esporos, a riqueza de espécies e os índices de Shannon, de Pielou e de Simpson verificados na estação seca encontram-se nas Figuras 12 e 13. As diferenças significativas observadas foram da densidade de esporos e da riqueza de espécies sob o cupuaçu e a pupunha quando cultivados em monocultivos. Sob o cupuaçu foram encontrados maiores densidades de esporos e riqueza de espécies. Sob uma mesma espécie vegetal cultivada em monocultivo e no SAF não foram verificadas diferenças significativas para nenhum dos parâmetros. Tampouco observaram-se diferenças significativas entre a linha e a entrelinha nos monocultivos e no SAF.

$\mathrm{Na}$ estação chuvosa a uniformidade foi ainda maior (Figura 14 e 15), não sendo observadas diferenças significativas entre o cupuaçu e a pupunha em nenhum dos sistemas.

A não alteração da diversidade de comunidades de fungos MA devido à mudança no sistema de uso da terra ou práticas de manejo envolvendo espécies perenes nos trópicos úmidos tem sido observada por alguns autores (Boddington \& Dodd, 2000; Carpenter et al., 2001; Picone, 2000; Wilson et al., 1994).

Alguns resultados têm indicado que o tempo de instalação do sistema ou a sua estabilidade é mais importante do que os sistemas em si em algumas situações. Aumento da diversidade das comunidades de fungos MA com o avanço da maturidade de plantações de Terminalia spp. foi observado por Wilson et al. (1994) na Costa do Marfim e por Mason et al. (1994) nos Camarões. Processo semelhante também foi 

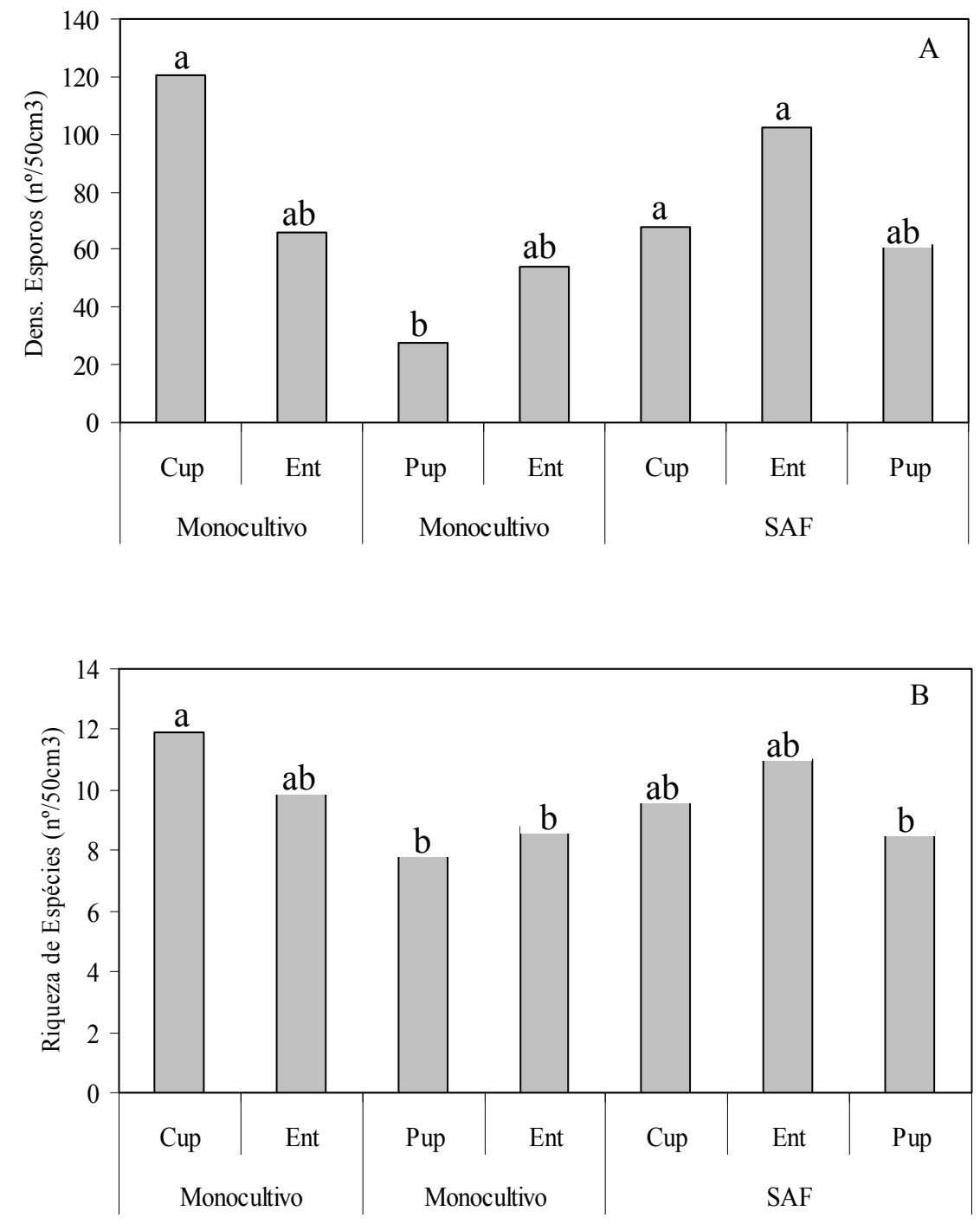

Figura 12 - Densidade de esporos (A) e riqueza de espécies (B) das comunidades de fungos MA sob o cupuaçu, a pupunha e as entrelinhas nos monocultivos e no SAF, na estação seca. Médias com mesma letra não diferem entre si (teste $\mathrm{t}, \mathrm{p}<0,05) . \mathrm{n}=9$ 



Figura 13 - Índices de diversidade de Shannon (A), de equitabilidade de Pielou (B) e de dominância de Simpson (C) das comunidades de fungos MA sob o cupuaçu, a pupunha e as entrelinhas nos monocultivos e no SAF, na estação seca. $n=9$ 

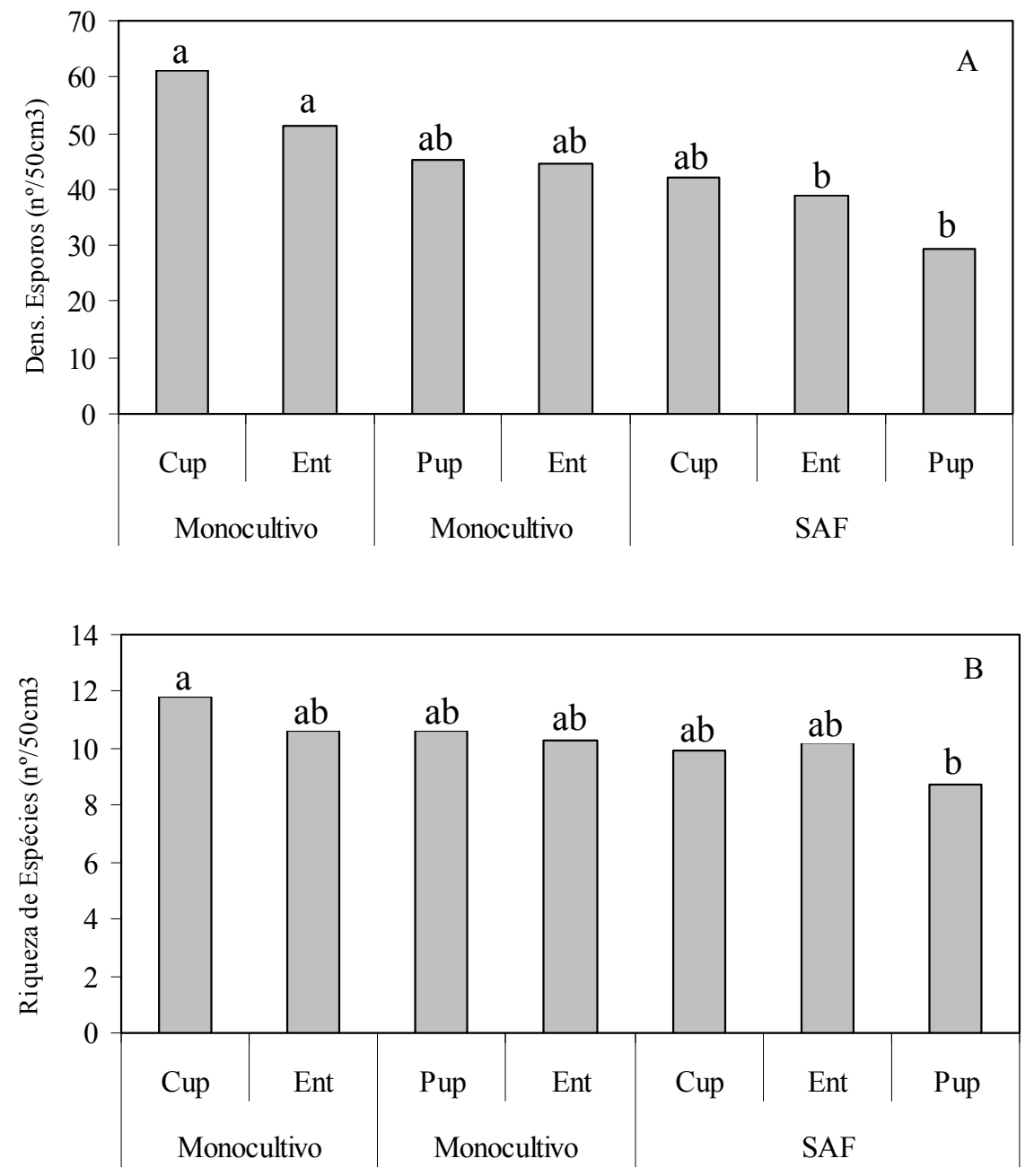

Figura 14 - Densidade de esporos (A) e riqueza de espécies (B) das comunidades de fungos MA sob o cupuaçu, a pupunha e as entrelinhas nos monocultivos e no SAF, na estação chuvosa. Médias com mesma letra não diferem entre si (teste $\mathrm{t}, \mathrm{p}<0,05) . \mathrm{n}=9$ 

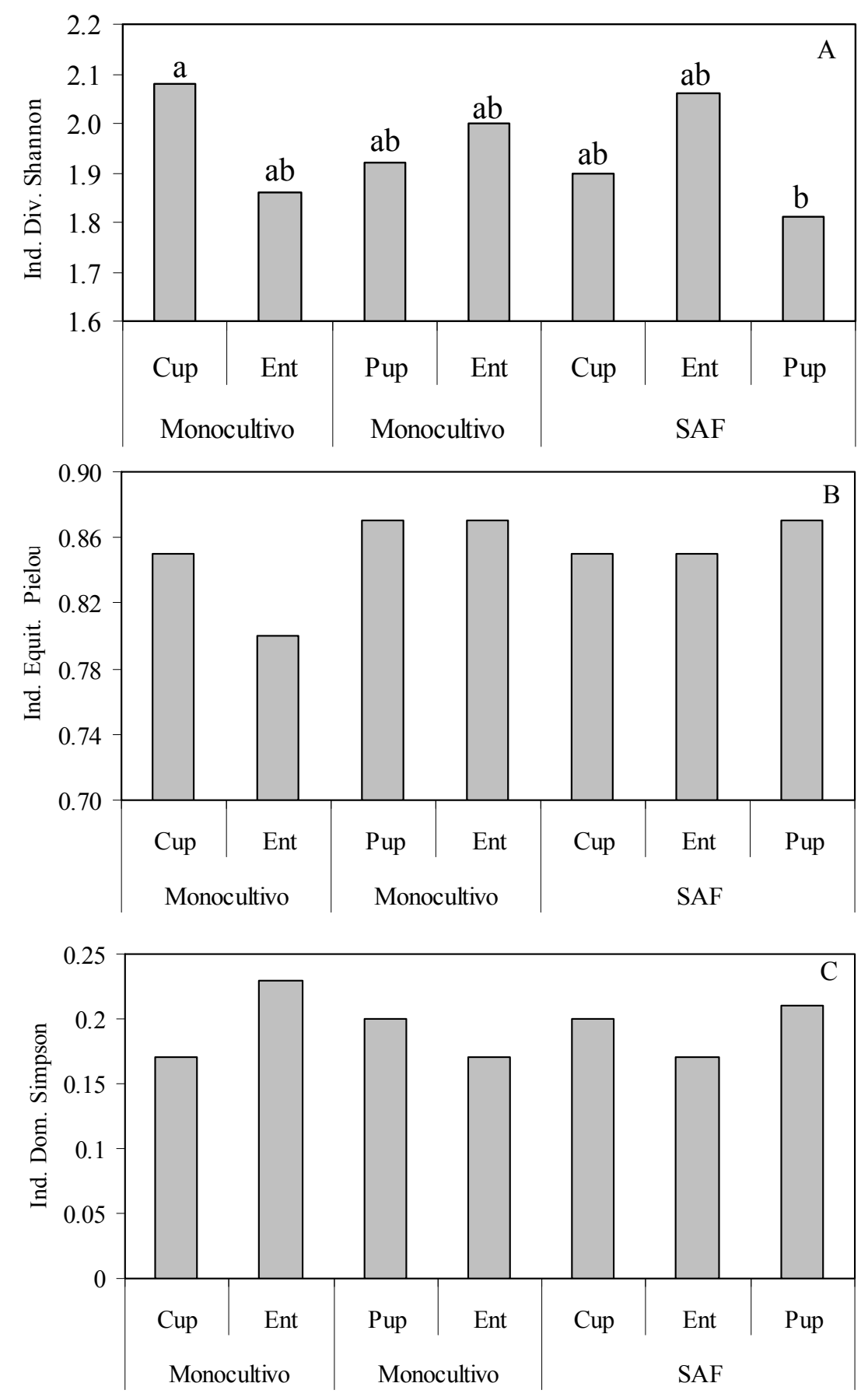

Figura 15 - Índices de diversidade de Shannon (A), de equitabilidade de Pielou (B) e de dominância de Simpson (C) das comunidades de fungos MA sob o cupuaçu, a pupunha e as entrelinhas nos monocultivos e no SAF, na estação chuvosa. Médias com mesma letra não diferem entre si (teste $t$, $\mathrm{p}<0,05) . \mathrm{n}=9$ 
observado por Feldmann et al. (2002) em plantios de seringueira na Amazônia Brasileira. No Rio Grande do Sul, Fochi et al. (2004), estudando a diversidade de pomares de citrus em sistemas de manejo orgânico e convencional, verificaram diferenças apenas na riqueza de espécies entre pomares de idades diferentes, mas não entre os sistemas de manejo.

Os sistemas monocultivo e SAF estudados nesse trabalho foram implantados na mesma época, contrastando apenas na composição e distribuição das espécies cultivadas e no nível de adubação aplicada. O histórico de nove anos de manejo levou a algumas diferenças de fertilidade. Por outro lado, no manejo desses monocultivos e do SAF não foram usadas máquinas pesadas e aplicadas apenas quantidades desprezíveis de fungicidas e inseticidas durante esse período. Portanto, após a implantação não foram realizadas práticas que provocassem grandes distúrbios nesses agrossistemas. Baseado na maioria dos índices de avaliação da diversidade utilizados, pode-se dizer que nesses sistemas há um patamar homogêneo de diversidade entre as comunidades de fungos MA. Esse patamar de diversidade é semelhante ao encontrado no ambiente natural na região (Feldmann et al., 2002), indicando que nos agrossistemas estudados as comunidades de fungos MA tendem a uma estabilidade. Isso leva a uma hipótese de que as comunidades desses fungos apresentariam um grau considerável de resiliência. Em parcelas adjacentes as avaliadas neste trabalho, foi detectado um intenso processo de diversificação dessas comunidades fúngicas após o preparo da área para plantio com o uso da prática da derruba e queima (Feldmann et al., 2002). O número de espécies passou de quatro, aos seis meses após a queima, para 14, decorridos 36 meses do preparo de solo. É possível que, após nove anos as comunidades sob o cupuaçu e a pupunha nos diferentes sistemas, embora difiram na sua composição, já tenham atingido esse patamar de diversificação. Contudo, não sabemos se essa diversidade observada é ou não similar ao encontrado nas condições naturais. Na floresta adjacente ao experimento não há ocorrência de pupunha ou cupuaçu nativo que pudessem ser usados como controles.

No presente trabalho a média do número de espécies de fungos variou de 8,4 a 11,9 por amostra nas diferentes espécies de planta e sistemas (Figuras 13 e 15). Esse 
valor é alto, considerando que, nesse estudo, essa média refere-se ao número de espécies de fungos sob uma única planta para o cupuaçu e por touceira no caso da pupunha. Os estudos não têm apresentado esse valor de forma clara e tampouco descrevem se a individualidade das amostras foi considerada no cálculo das médias. Em alguns estudos as amostras compostas analisadas são tomadas de várias plantas o que mascara a quantidade de espécie de fungos MA associadas a uma única planta. A esse respeito, considerando o valor médio por planta, França (2004) encontrou no estado de São Paulo uma média de 3,3 e 7,5 em citrus sob manejo convencional e orgânico, respectivamente. Portanto, os valores observados no presente estudo são até superiores àqueles do sistema mais diversificado observado por França (2004).

A relação entre o número de espécies e a densidade de esporos em cada amostra nas estações seca e chuvosa encontra-se na Figura 16 . Essa relação seguiu um modelo logarítmico, onde se observa na primeira parte da curva que um aumento na densidade de esporos foi acompanhado de aumento do número de espécies. A maioria das amostras concentrou-se nessa região da curva. Isso indica que, em geral, os aumentos da densidade de esporos não resultaram do aumento de uma única espécie e sim pelo surgimento de outras espécies na amostras. Esse resultado demonstra que houve um equilíbrio entre as populações que compõem as comunidades. Tal tendência é confirmada pela dominância baixa e elevada equitabilidade e diversidade, medidos pelos índices de Simpson, Pielou e de Shannon, respectivamente (Figuras 13 e 15).

Sieverding (1991) relata que há um aumento da densidade de esporos de fungos MA na transição de sistemas naturais, mais estáveis, para agrossistemas. Segundo o autor, isto é resultado do aumento da esporulação de espécies em resposta a estresses ambientais e à instabilidade. Como conseqüência, há um aumento da dominância na comunidade de algumas espécies mais adaptadas a essas condições. Contudo, os agrosistemas estudados nesse trabalho apresentaram valores de dominância, equitabilidade e diversidade semelhantes a sistemas naturais estudados nos trópicos úmidos (Feldmann et al., 2002; Johnson \& Wedin, 1997). 

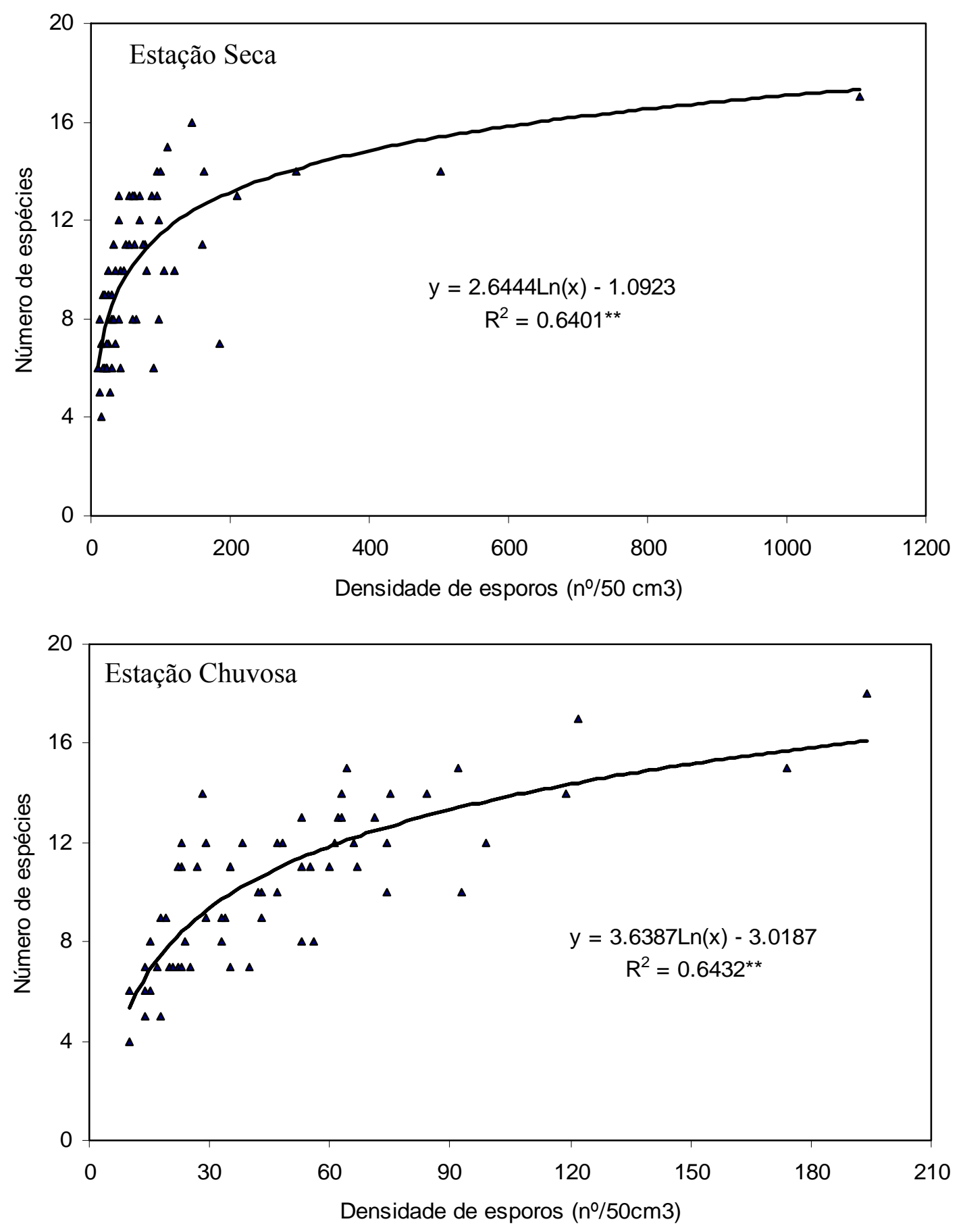

Figura 16 - Relação entre riqueza (números de espécies) e densidade de esporos nas amostras das estações seca e chuvosa 
A diversificação de hospedeiro tem sido colocada como o fator responsável pelo aumento da diversidade de fungos MA (Miller \& Jackson, 1998; Moreira \& Siqueira, 2002). Os resultados obtidos nesse trabalho não indicam que nos sistemas estudados a diversificação de hospedeiro tenha impacto sobre a diversidade de fungos MA. O monocultivo de pupunha, apesar de possuir grande dominância de raízes dessa espécie vegetal, não reduziu a diversidade dos fungos associados a essa espécie quando comparado ao SAF, sistema de maior diversidade de hospedeiros (Figuras 12, 13, 14 e 15). Todavia, o monocultivo de pupunha promoveu uma seleção de espécies de fungos MA, como pode ser verificado pelos resultados da análise de agrupamento baseada no perfil de freqüência das espécies de fungos MA (Figura 11).

Pouco se pode dizer sobre o impacto que as alterações da composição das espécies com a manutenção da diversidade da comunidade de fungos MA podem ter no funcionamento da simbiose micorriza e, por conseqüência, nos agroecossistemas. Resultados obtidos por Heijden et al. (1998) demonstraram, em condições experimentais, que o número de espécies da comunidade de fungos MA pode ser um fator determinante do efeito da simbiose micorrízica no funcionamento dos ecossistemas. Contudo, tais resultados referem-se ao somatório dos efeitos sobre 15 diferentes espécies vegetais das comunidades de fungos MA estudadas num macrocosmo, sendo que os efeitos dessas comunidades fúngicas variaram entre as espécies vegetais. A transposição dessas evidências para agrossistemas parece ser difícil, visto que tais sistemas apresentam menor diversidade vegetal, com o foco concentrado nas espécies cultivadas. Outra dificuldade na relação entre diversidade e funcionalidade reside no fato de que fungos MA podem apresentar amplo espectro funcional dentro de uma mesma espécie, como constatado recentemente por Munkvold et al. (2004). Além disso, verifica-se que essa característica funcional pode se alterar ao longo das gerações de uma isolinha, podendo, inclusive, haver perda da capacidade em promover o crescimento do hospedeiro (Feldmann, 1998). Embora Moreira \& Siqueira (2002) levantem a possibilidade de que haja nos agrossistemas uma seleção de espécies de fungos MA para a sobrevivência e não para a eficiência simbiótica, a plasticidade 
intraespecífica resultante da diversidade genética e funcional indicam que essa seleção pode ocorrer dentro de uma mesma espécie.

Assim sendo, para que se tenham avanços mais consistentes sobre a ecologia de micorrizas arbusculares nesse quadro extremamente complexo, é necessário o desenvolvimento de abordagens e metodologias aplicáveis diretamente no campo, que permitam obter informações mais precisas e mais próximas das condições naturais, sobre o funcionamento desta simbiose em comunidades de fungos MA contrastantes. Tais indicadores do funcionamento da simbiose poderiam ser aqueles relacionados à absorção de P, usando radioisótopos como proposto por Schweiger \& Jakobsen (1999). Outra possibilidade é a avaliação da expressão de genes característicos do funcionamento da simbiose.

\subsection{Diversidade de Fungos MA Associados às Raízes de Pupunha Avaliada pelo Sequenciamento de Mini Biblioteca de Amplicons de região do rDNA 18S}

A avaliação da diversidade de fungos MA através de técnicas moleculares tem sido preconizada como uma alternativa vantajosa à avaliação baseada em taxonomia clássica devido a possibilidade de reduzir a subjetividade envolvida na caracterização morfológica de esporos, base da taxonomia clássica, e de identificar espécies colonizando as raízes, impossível de ser realizada de outra forma .

Para estimar a diversidade de fungos MA associada às raízes de pupunha cultivada em SAF, duas bibliotecas de região do rDNA $18 \mathrm{~S}$ foram construídas e seqüenciadas a partir de duas amostras simples de raízes coletadas em duas plantas diferentes. De cada amostra foram obtidas 96 seqüências e, após a análise da qualidade, no programa Phrep/Phrap (Ewing et al., 1998; Ewing \& Green, 1998), foram selecionadas 79 e 80 seqüências válidas das amostras um e dois, respectivamente. As seqüências obtidas foram agrupadas em unidades taxonômicas operacionais (UTO), com base na sua similaridade através do programa CAP3 (Huang \& Madan, 1999). Na amostra um e dois (Tabela 9 e 10) foram obtidas seqüências com similaridade a fungos MA e a outros fungos não micorrízicos. Entre aquelas que apresentaram similaridade 
Tabela 9. Números de sequências obtidas e similaridade com seqüências depositadas no GenBank de cada unidade taxonômica operacional (UTO) da mini biblioteca de amplicons de $18 \mathrm{~S}$ das raízes de pupunha cultivada em SAF, amostra um

\begin{tabular}{|c|c|c|c|}
\hline $\begin{array}{l}\text { Código } \\
\text { UTO }\end{array}$ & Organismo mais Próximo & $\begin{array}{l}\text { Similarida } \\
\text { de }(\%)\end{array}$ & $\begin{array}{c}\mathrm{N}^{\circ} \\
\text { Seq. }\end{array}$ \\
\hline Contig 1 & $\begin{array}{l}\text { Glomus sp. não isolado, simbionte da espécie vegetal } \\
\text { Voyria corymbosa }\end{array}$ & 98 & 7 \\
\hline Contig 2 & $\begin{array}{l}\text { Acaulospora sp não isolada, simbionte da espécie } \\
\text { vegetal Graffenrieda emarginata (Melastomataceae) em } \\
\text { floresta tropical úmida }\end{array}$ & 98 & 11 \\
\hline Contig 3 & Glomus sp. não isolado & 97 & 11 \\
\hline Contig 6 & Glomus sinuosum & 96 & 37 \\
\hline A05 01 & Glomus sinuosum & 92 & 1 \\
\hline F03 11 & Glomus manihotis & 98 & 1 \\
\hline G03 13 & Glomus sinuosum & 95 & 1 \\
\hline Contig 4 & $\begin{array}{ll}\text { Hyponectria buxi } & \text { (Ascomycota; Pezizomycotina; } \\
\text { Sordariomycetes; } & \text { Xylariomycetidae; Xylariales; } \\
\text { Hyponectriaceae) } & \end{array}$ & 99 & 7 \\
\hline Contig 5 & $\begin{array}{l}\text { Coniosporium sp., Ascomicota mitospórico isolado do } \\
\text { solo }\end{array}$ & 96 & 2 \\
\hline $\mathrm{C} 03$ & Ascomiceto de rizosfera não cultivado & 99 & 1 \\
\hline
\end{tabular}


Tabela 10. Números de sequências obtidas e similaridade com seqüências depositadas no GenBank de cada unidade taxonômica operacional (UTO) da mini biblioteca de amplicons de $18 \mathrm{~S}$ das raízes de pupunha cultivada em SAF, amostra dois

\begin{tabular}{|c|c|c|c|}
\hline $\begin{array}{l}\text { Código } \\
\text { UTO }\end{array}$ & Organismo mais próximo & $\begin{array}{l}\text { Similarida } \\
\text { de }(\%)\end{array}$ & $\mathrm{N}^{0} \mathrm{Seq}$ \\
\hline Contig 1 & $\begin{array}{l}\text { Acaulospora sp. não isolada, simbionte da espécie vegetal } \\
\text { Graffenrieda emarginata (Melastomataceae) }\end{array}$ & 98 & 4 \\
\hline Contig 2 & Glomus sinuosum & 96 & 23 \\
\hline Contig 3 & $\begin{array}{l}\text { Acaulospora sp. não isolada, simbionte da espécie vegetal } \\
\text { Graffenrieda emarginata (Melastomataceae) }\end{array}$ & 98 & 11 \\
\hline Contig 4 & $\begin{array}{l}\text { Glomus sp não isolado, simbionte da espécie vegetal } \\
\text { Voyria corymbosa }\end{array}$ & 98 & 20 \\
\hline Contig 5 & Glomus sp. não isolado & 97 & 5 \\
\hline Contig 6 & Glomus sinuosum & 97 & 5 \\
\hline Contig 7 & $\begin{array}{l}\text { Acaulospora sp. não isolada, simbionte da espécie vegetal } \\
\text { Graffenrieda emarginata (Melastomataceae) }\end{array}$ & 94 & 3 \\
\hline A11 01 & Acaulospora sp. & 92 & 1 \\
\hline $\mathrm{C} 046$ & $\begin{array}{l}\text { Acaulospora sp. não isolada, simbionte da espécie vegetal } \\
\text { Graffenrieda emarginata (Melastomataceae) }\end{array}$ & 99 & 1 \\
\hline D11 07 & Glomus sp. não isolado & 95 & 1 \\
\hline E06 10 & Glomus sinuosum & 94 & 1 \\
\hline G07 13 & $\begin{array}{l}\text { Glomus sp. não isolado, simbionte da espécie vegetal } \\
\text { Chasmanthium sessiliforum }\end{array}$ & 95 & 1 \\
\hline H01 15 & Glomus sp. não isolado & 92 & 1 \\
\hline B08 04 & Fusarium merismoides & 99 & 1 \\
\hline E01 09 & Gibberella pulicaris & 98 & 1 \\
\hline F07 11 & Colletotrichum lindemuthianum & 99 & 1 \\
\hline
\end{tabular}


com fungos MA, os maiores valores de similaridade ocorreram apenas com espécies dos gêneros Glomus e Acaulospora. Na amostra um, 13,92\% das seqüências válidas apresentaram similaridade a espécies de Acaulospora, enquanto que 73,42\% foram similares a espécies de Glomus. Na amostra dois, esses valores foram de 25,00\% e $71,25 \%$ para Acaulospora e Glomus, respectivamente. Isso confirma a grande predominância desses gêneros nas condições ambientais desse estudo, como já fora verificado na avaliação dos esporos presentes na rizosfera. Em estudo usando a mesma região do rDNA 18S, Husband et al. (2002) também verificaram a predominância dos gêneros Glomus e Acaulopsora em raízes de plantas em floresta tropical úmida. Porém, apesar da ocorrência reduzida, esses autores também encontraram seqüências do gênero Scutellospora.

Nesse estudo apenas uma UTO em cada biblioteca analisada apresentou índice elevado de similaridade (>97\%) com seqüências de espécies de fungos MA previamente isoladas. Na amostra um, a UTO F03 11 apresentou similaridade de 98\% com Glomus manihotis, já na amostra dois, a UTO Contig 3 apresentou similaridade de $97 \%$ com Glomus sinuosum. As demais UTO apresentaram índices baixos de similaridade com seqüências anteriormente depositadas ou índices elevados com seqüências de espécies não isoladas (originadas de amostras ambientais). Tais indícios apontam para a existência de grande diversidade genética ainda não registrada nas amostras avaliadas . É necessário ressaltar que a identificação de fungos MA a partir de regiões do rDNA $18 \mathrm{~S}$ ainda necessita do estabelecimento de parâmetros próprios, visto que o caráter heterocariótico desses fungos confere-lhes grande variabilidade genética intraespecífica (Burggraaf \& Boehringer 1989; Koch et al., 2004; Kuhn et al., 2001; Viera \& Glen 1990).

As UTO de fungos MA obtidas nas amostras um e dois foram utilizadas para a determinação de suas relações filogenéticas (Figuras 17 e 18).

$\mathrm{Na}$ amostra um (Figura 17), das sete UTOs obtidas, três agruparam com espécies do gênero Glomus, enquanto quatro não agruparam com nenhum dos gêneros. Apesar disto, essas UTOs apresentaram os maiores valores de similaridade com 


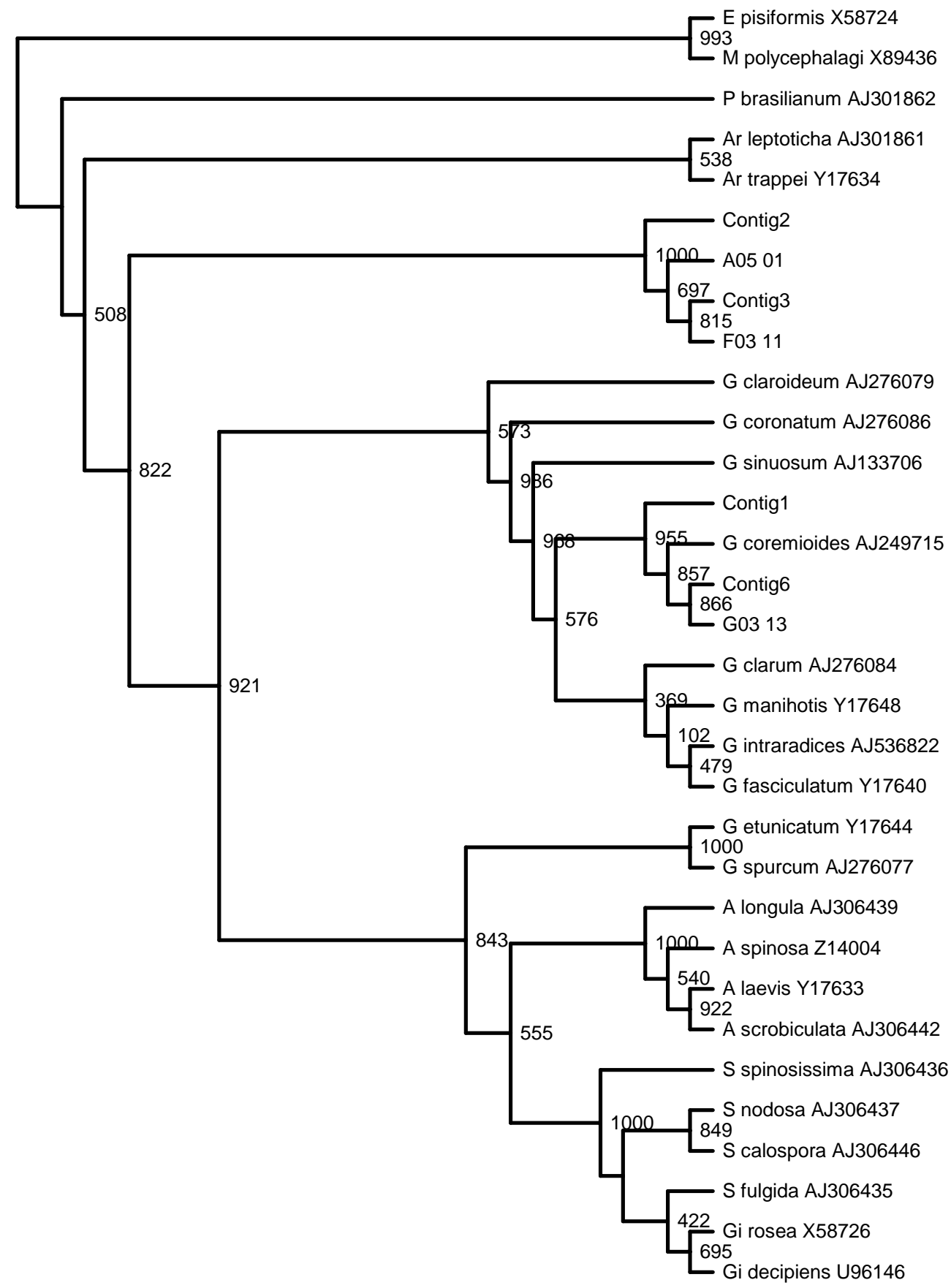

Figura 17 - Relações filogenéticas entre as UTOs identificadas nas raízes de pupunha culivada em SAF, amostra um. Ar - Archaeospora; A - Acaulospora; E Endogone; G - Glomus; Gi - Gigaspora; M - Mortierella ; S - Scutellopora 


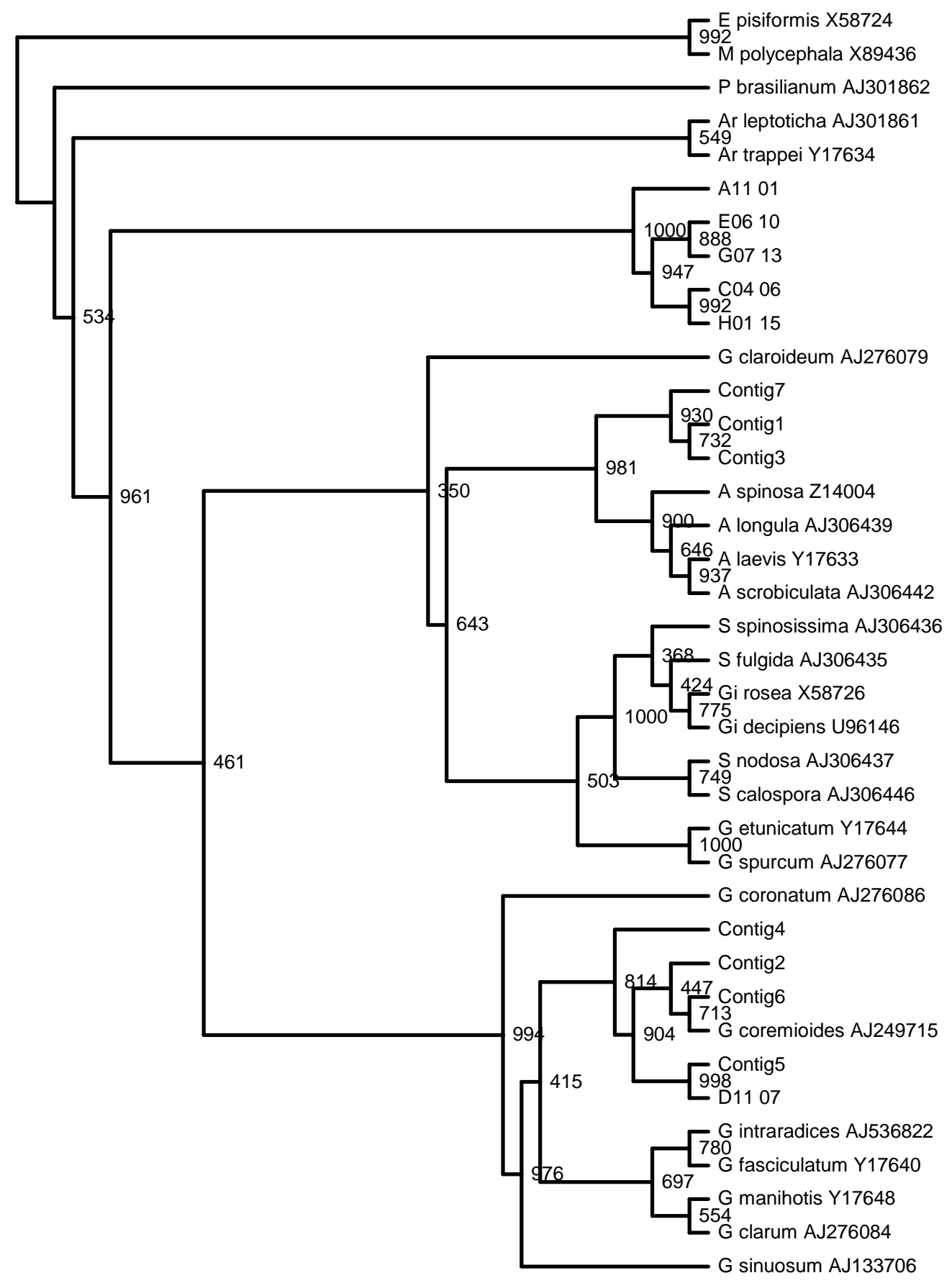

Figura 18 - Relações filogenéticas entre as UTOs identifcadas nas raízes de pupunha cultivada em SAF, amostra dois. Ar - Archaeospora; A - Acaulospora; E Endogone; G - Glomus; Gi - Gigaspora; M - Mortierella ; S - Scutellopora 
espécies de Glomus. Tal resultado pode indicar que estas sejam UTOs correspondente a espécies que integrem novos grupos dentro do gênero, visto que Glomus constitui um gênero polifilético (Schwarzott et al., 2001).

$\mathrm{Na}$ amostra dois (Figura 18), três UTO agruparam com espécies de Acaulospora, cinco com Glomus e cinco formaram grupo distinto, como observado na amostra um. Dessas UTOs, apenas a A11 01 não apresentou similaridade com espécies de Glomus . Considerando que há muito erro de identificação de seqüências depositadas nos bancos de dados e que essa UTO apresentou os maiores valores com uma espécie ainda não isolada, é possivel que todos do grupo pertençam a um grupo de espécies de Glomus.As espécies cujos esporos predominaram na rizosfera de pupunha (ver primeira parte deste estudo) não estiveram presentes na raiz por ocasião da coleta, a partir da avaliação dos amplicons do rDNA 18S. Isto pode indicar que as espécies mais esporulantes em dado momento não são necessariamente as predominantes no interior das raízes, indicando que pode haver uma dissociação entre nível de esporulação e de colonização radicular. Outra possibilidade é de haver uma sazonalidade de colonização das espécies, com o máximo de colonização e de esporulação ocorrendo em épocas diferentes. Sucessão de espécies de fungos MA colonizando raízes já foi identificada por Husband et al. (2002), através das análises de seqüências de região do rDNA 18S obtidas das raízes de mudas de duas espécies vegetais, em floresta tropical do Panamá. Muito embora os autores tenham identificado como sucessão a mudança do perfil de espécies ao longo do período de um ano de avaliação, nada impede que essas mudanças sejam cíclicas caracterizando, assim, um fenômeno sazonal.

Apesar da divergência quanto à identidade das espécies colonizando as raízes e dos esporos presentes numa mesma época, a riqueza de UTO de fungos MA identificada nas raízes de pupunha estiveram na mesma faixa da riqueza de espécies identificadas entre os esporos presentes na rizosfera. Tal fato indicaria que mesmo que haja sucessão ou sazonalidade, a estrutura da comunidade parece manter-se.

A partir da análise de rarefação (Figura 19), pode-se verificar o número máximo de UTOs e a quantidade de clones que necessitariam ser seqüenciados para a 

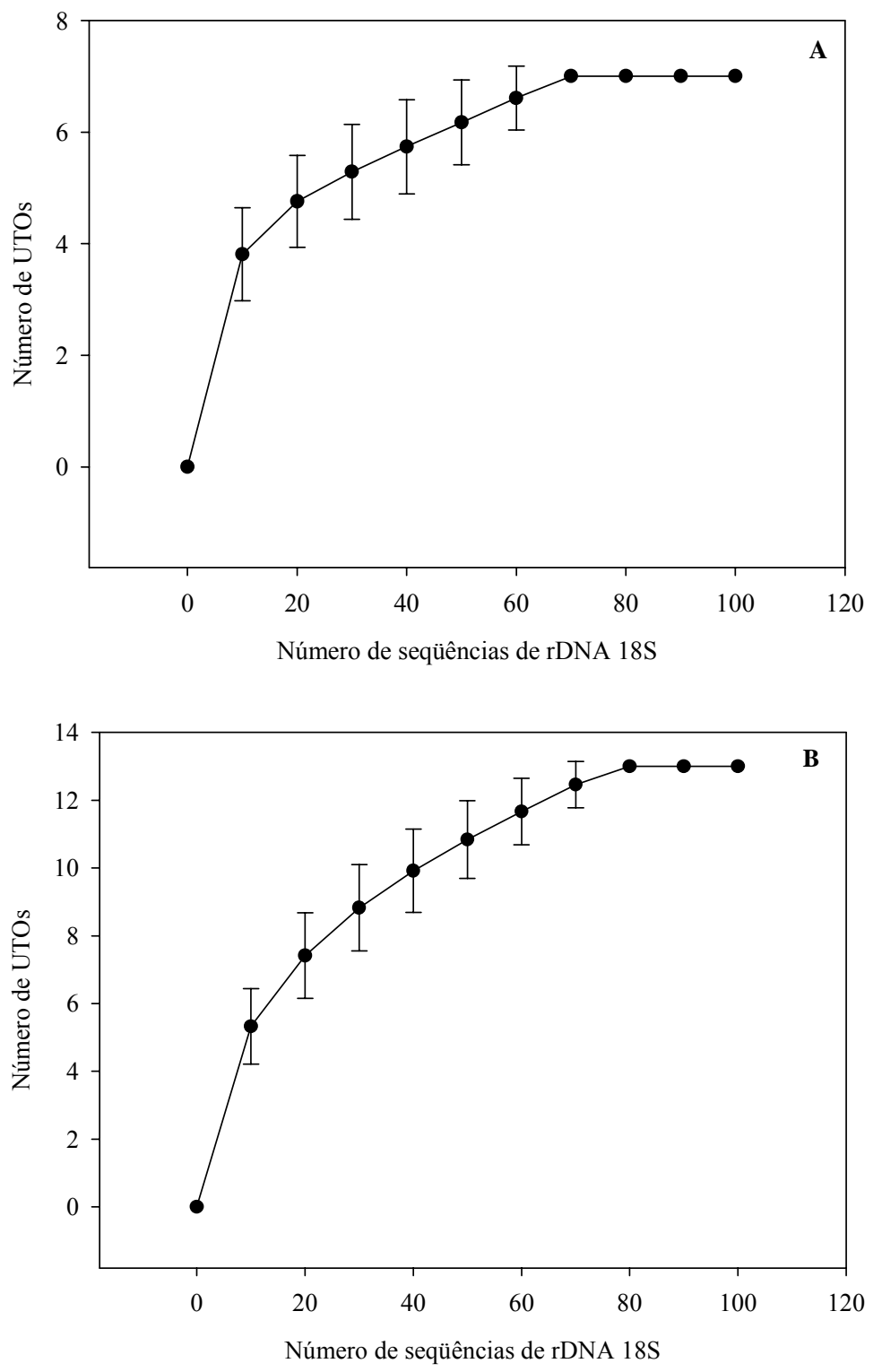

Figura 19 - Análise de rarefação de seqüências de rDNA $18 \mathrm{~S}$ de fungos MA colonizando raízes de pupunha cultivada em SAF. A - amostra um e B - amostra dois 
representação da diversidade de fungos MA presentes nas raizes de pupunha. Pela análise de rarefação na amostra um o número máximo de UTOs seriam de sete, sendo necessário o sequenciamento de 70 clones. $\mathrm{Na}$ amostra dois, esses valores foram de 13 e 80, respectivamente. Nesse estudo foram seqüenciados 96 clones, portanto acima do número de clones necessário a representação da diversidade existente. Em outros estudos de diversidade de fungos MA de amostras ambientais, tem-se realizado uma análise prévia dos clones, baseada no padrão de RFLP, como estratégia de redução do número de clones a serem seqüenciados (Helgason et al., 1998; Husband et al., 2002; Opik et al., 2003). No presente estudo apesar de não ter sido realizada tal estratégia, o número de clones seqüenciados se mostrou suficiente para o objetivo proposto.

Nesse estudo verificou-se que o "primer" AM1 (Helgason et al., 1998) foi capaz de amplificar regiões do rDNA $18 \mathrm{~S}$ de outros fungos não micorrízicos associados às raizes. Sendo assim, o uso desse "primer" para avaliação da diversidade de fungos MA, em amostras ambientais, deve ser cercada de certo cuidado. Em algumas abordagens metedológicas baseadas em PCR têm adotado a estratégia de análise eletroforética (AFLP, DGGE, RFLP) do rDNA 18S, para avaliação de diversidade desse grupo de organismo. Nessas condições, o uso do "primer" AM1 deve ser acompanhado, obrigatoriamente, do sequenciamento, com o objetivo de confirmar se os amplicons obtidos são de fungos MA. Do contrário, há risco de superestimativa da diversidade avaliada.

\subsection{Considerações Metodológicas}

O esporo constitui apenas uma fase da vida dos fungos MA. Segundo Morton et al. (1995), muitas espécies permanecem sem esporular se a condições ambientais permitirem. Sendo assim, estudos de ocorrência de fungos MA baseados em avaliação de esporos teriam algumas limitações. Tais limitações tornam-se mais críticas nos estudos onde a identidade da espécie é um aspecto essencial. No presente trabalho buscou-se entender a relação entre a comunidade e os sistemas de cultivo. A partir dessa 
abordagem, não identificar algumas populações não esporulantes possivelmente represente um risco menor do que quando se busca levantar a ocorrência de populações com o objetivo exclusivo de recuperar recursos genéticos para uso em programas de desenvolvimento de inoculantes. Nesse aspecto, Morton et al. (1995 ) salientam que, para fins ecológicos, o estudo da ocorrência de fungos MA baseado em esporos constitui em estratégia eficaz. O uso de plantas armadilhas tem sido uma estratégia recomendada como forma de recuperar espécies de fungos MA cujos esporos não foram encontrados no campo por ocasião realização das coletas (Brundrett et al., 1996; Sieverding, 1991). Contudo, a taxa de recuperação dessas espécies através de plantas armadilhas pode ser, muitas vezes, relativamente baixa (Colozzi-Filho, 1999; Cuenca \& Meneses, 1996; Moreira-Souza et al., 2003). Assim, o estudo da ecologia de fungos MA baseado nas populações de esporos do campo apesar de suas limitações, ainda representa uma estratégia aceitável.

Nesse trabalho foi possível estimar a diversidade (riqueza de espécies) de fungos MA avaliada pelas populações de esporos presentes na rizosfera e pela abordagem PCR-Sequenciamento de mini biblioteca do rDNA de fungos MA associados às raízes. Verificous-se que os dois métodos embora equivalentes sob o ponto de vista de estimativa da diversidade, representam comunidades diferentes. Portanto, quando se pretende avaliar as relações existentes na comunidade de fungos MA de forma mais ampla, essas metodologias seriam complementares. 


\section{CONCLUSÕES}

- A colonização micorrízica arbuscular no cupuaçu e na pupunha foi alterada pelo sistema de manejo adotado, sendo observadas maiores taxas de colonização no sistema de monocultivo;

- A dinâmica sazonal da colonização micorrízica arbuscular foi diferente em cupuaçu e pupunha;

- A densidade total dos esporos de fungos MA sob o cupuaçu não foi alterada pelo manejo ou pela época do ano;

- O tipo de efeito do sistema de manejo na densidade total de esporos de fungos MA sob a pupunha foi diferente nas duas épocas do ano;

- O número de populações de fungos MA encontrados nos agrossistemas de cupuaçu e pupunha foi elevado, com grande número de espécies de freqüência considerada rara;

- As espécies A. mellea, A. aff. mellea e G. macrocarpum foram as mais frequentes no cupuaçu e na pupunha em todos os sistemas de manejo;

- O manejo adotado alterou a composição das comunidades de fungos MA associados à pupunhan, não sendo esse efeito muito claro no cupuaçu.;

- O cupuaçu e a pupunha apresentaram comunidades de fungos MA com alta diversidade de espécies de fungos MA, independente do sistema de manejo adotado;

- O sequenciamento de mini bibliotecca de amplicons de região do gene rDNA $18 \mathrm{~S}$ se mostrou viável na avaliação da diversidade de fungos MA, revelando alta diversidade genética de fungos MA associados às raízes de pupunha. 


\section{REFERÊNCIAS BIBLIOGRÁFICAS}

ALBUQUERQUE, P.P. Aspectos ecológicos de populações de fungos micorrízicos arbusculares em reflorestamentos e na mata nativa de Araucaria angustifolia (Bert.) O. Kutze. Lages, 2003. 61p. Dissertação (Mestrado) - Universidade do Estado de Santa Catarina.

ALlEN, E.B.; RINCON, E.; ALLEN, M.F.; PEREZ-JIMENEZ, A.; HUANTE, P. Disturbance and seasonal dynamics of mycorrhizae in a tropical deciduous forest in Mexico. Biotropica, v. 30, n. 2, p. 261-274, 1998.

ANDRADE, F.G.; SÁ, C.P.; ALMEIDA, N.F. Uma visão prospectiva do cupuaçu nos limites do Acre: vilas Nova Califórnia e Extrema, RO. Rio Branco: EmbrapaCPAF/AC, 1998. 18p. (Embrapa-CPAF/AC. Circular Técnica, 21).

ANTONIOLLI, Z.I.; SCHACHTMAN, D.P.; OPHEL-KELLER, K.; SMITH, S.E. Variation in rDNA ITS sequences in Glomus mosseae and Gigaspora margarita spores from a permanent pasture. Mycological Research, v. 104, n. 6, p. 708-715, 2000.

BODDINGTON, C.L.; DODD, J.C. The effect of agricultural practices on the development of indigenous arbuscular mycorrhizal fungi. I. Field studies in an Indonesian ultisol. Plant and Soil, v. 218, n. 1/2, p. 137-144, 2000. 
BOVI, M.L.A., LAMBAIS, M.R., TUCCI, M.L.S.; SPIERING, S.H. Biomass accumulation and vesicular-arbuscular mycorrhizal colonization in pejibaye (Bactris gasipaes) as a function of NPK fertilization.. Acta Horticulturae, v. 513, n. 3, p. $153-168,1998$.

BRUNDRETT, M.; BOUGHER, N.; DELL, B.; GROVE, T.; MALAJCZUK, N. Working with mycorrhizas in forestry and agriculture. Canberra: Australian Center for International Agricultural Research, 1996. 374p. (ACIAR. Monograph, 32)

BURGGRAAF, A.J.P.; BOEHRINGER , J.E. Absence of nuclear DNA synthesis in vesicular-arbuscular mycorrhizal fungi during in vitro development. New Phytologist, v. 111, n. 1, p. 25-33, 1989.

CARPENTER, F.L.; MAYORGA, S.P.; QUINTERO, E.G.; SCHROEDER, M. Landuse and erosion of a Costa Rican Ultisol affect soil chemistry, mycorrhizal fungi and early regeneration. Forest Ecology and Management, v. 144, n. 1/3, p. 1-17, 2001.

CARRENHO, R.; SILVA, E. S.; TRUFEM, S.F.B.; BONONI, V.L.R. Successive cultivation of maize and agricultural practices on root colonization, number of spores and species of arbuscular mycorrhizal fungi. Brazilian Journal of Microbiology, v. 32, n. 4, p. 262-270, 2001.

CARVALHO, A.R.V. Associação de bactérias diazotróficas e fungos micorrízicos arbusculares em mudas de pupunheira (Bactris gasipaes H.B.K.) e de dendezeiro (Elaeis guineensis JACK.). Seropédica, 1997. 230p. Tese (Doutorado)Universidade Federal Rural do Rio de Janeiro.

CARVALHO, L.M.; CORREIA, P.M.; RYEL, R.J.; MARTINS-LOUCAO, M.A. Spatial variability of arbuscular mycorrhizal fungal spores in two natural plant communities. Plant and Soil, v. 251, n. 2, p. 227-236, 2003. 
CAVAGNARO, T.R.; GAO, L.L.; SMITH, F.A.; SMITH, S.E. Morphology of arbuscular mycorrhizas is influenced by fungal identity. New Phytologist, v. 151, n. 2, p. 469-475, 2001.

CAVAlCANTE, P.B. Frutas comestíveis da Amazônia. Belém: CNPq; Museu Paraense Emílio Goeldi, 1996. 279 p.

CHELIUS, M.K.; TRIPLETT, E.W. Rapid detection of arbuscular mycorrhizae in roots and soil of an intensively managed turfgrass system by PCR amplification of small subunit rDNA. Mycorrhiza, v. 9, n. 1, p. 61-64. 1999

CLAPP, J.P.; FITTER, A.H.; YOUNG, J.P.W. Ribosomal small subunit sequence variation within spores of an arbuscular mycorrhizal fungus, Scutellospora sp. Molecular Ecology, v. 8, n. 6, p. 915-921, 1999.

CLAPP, J.P.; RODRIGUEZ, A.; DODD, J.C. Inter- and intra-isolate rRNA large subunit variation in Glomus coronatum spores. New Phytologist, v. 149, n. 3, p. 539-554, 2001.

CLEMENT, C.R. The potential use of the pejibaye palm in agroforestry systems. Agroforestry Systems, v. 7, n. 3, p. 201-212, 1989.

CLEMENT, C.R.; HABTE, M. Genotypic Variation in Vesicular-Arbuscular Mycorrhizal Dependence of the Pejibaye Palm. Journal of Plant Nutrition, v. 18, n. 9, p. 1907-1916, 1995.

COLOZZI-FILHO, A.; CARDOSO, E.J.B.N. Detecção de fungos micorrízicos arbusculares em raízes de cafeeiro e de crotalária cultivada na entrelinha. Pesquisa Agropecuária Brasileira., v. 35, n. 10, p. 2033-2042, 2000.

CUENCA, G.; MENESES, E. Diversity patterns of arbuscular mycorrhizal fungi associated with cacao in Venezuela. Plant and Soil, v. 183, n. 2, p. 315-322, 1996. 
DODD, J.C.; ARIAS, I.; KOOMEN, I.; HAYMAN, D.S. The management of populations of vesicular-arbuscular mycorrhizal fungi in acid-infertile soils of a savanna ecosystem. 2. the effects of precrops on the spore populations of native and introduced VAM-fungi Plant and Soil, v. 122, n. 2, p. 241-247, 1990.

DOUDS JR., D.D.; MILLNER, P. Biodiversity of arbuscular mycorrhizal fungi in agroecosystems. Agriculture Ecosystems \& Environment, v. 74, n. 1/3, p. 77-93, 1999.

EMPRESA BRASILEIRA DE PESQUISA AGROPOECUÁRIA. Boletim agrometeorológico. Manaus: Embrapa, CPAA, 1997. 19p.

EWING, B.; GREEN, P. Base-calling of automated sequencer traces using Phred. II. Error probabilities. Genome Research, v. 8, n. 3, p. 186-194, 1998.

EWING, B; HILLER, L.; WENDL, M.; GREEN, P. Base-calling of automated sequencer traces using Phred/Phrap. I. Accuracy assessment. Genome Research, v. 8, n. 3, p. 175-185, 1998.

FELDMANN, F. The strain-inherent variability of arbuscular mycorrhizal effectiveness: II. Effectiveness of single spores. Symbiosis, v. 25, n. 1/3, p. 131143, 1998.

FELDMANN, F.; SILVA JR., J.P. ; LIBEREI, R. AMF spore community composition at natural and agricultural sites in Central Amazonia - a long term study. In. LIEBEREI, R.; BIANCHI, H. K.; BOEHM, V.; REISDORFF, C. (Ed.). Neotropical ecosystems. Geesthacht: GKSS, 2002. p. 669-682.

FELDMANN, F.; IDCZAK, E.; MARTINS, G.; NUNES, J.; GASPAROTTO, L.; PREISINGER, H.; MORAES, V. H. F.; LIEBEREI, R. Recultivation of degraded, fallow lying areas in Central Amazonia with equilibrated polycultures. Response of useful plants to inoculation with VA-mycorrhizal fungi. Journal of Applied Botany, v. 69, n. 3/4, p. 111-118, 1995. 
FERNANDES, A.B. Micorrizas vesículo-arbusculares em cafeeiros da região sul do estado de Minas Gerais. Lavras, 1987. 98p. Dissertação (Mestrado) - Universidade Federal de Lavras.

FERNANDES, A.B.; SIQUEIRA, J.O. Micorrizas vesicular-arbusculares em cafeeiros da região sul do estado de Minas Gerais. Pesquisa Agropecuária Brasileira, v. 24, n. 12, p. 1489-1498, 1989.

FISHER, J.B.; JAYACHANDRAN, K. Root structure and arbuscular mycorrhizal colonization of the palm Serenoa repens under field conditions. Plant and Soil, v. 217, n.1/2, p. 229-241, 1999.

FOCCHI, S.S.; DAL SOGLIO, F.K.; CARRENHO, R.; DE SOUZA, P.V.D.; LOVATO, P.E. Arbuscular mycorrhizal fungi in citrus cultivation under conventional and organic management. Pesquisa Agropecuária Brasileira, v. 39, n. 5, p. 469-476, 2004.

FRANÇA, S.C. Comunidades de fungos micorrízicos arbusculares nos manejo convencional e orgânico de citrus e suas interações com Phytophtora parasitica. Piracicaba, 2004. 106p. Tese (Doutorado) - Escola Superior de Agricultura Luiz de Queiroz, Universidade de São Paulo.

FRANKE-SNYDER, M.; DOUDS, D.D.; GALVEZ, L.; PHILLIPS, J.G.; WAGONER, P.; DRINKWATER, L.; MORTON, J.B. Diversity of communities of arbuscular mycorrhizal (AM) fungi present in conventional versus low-input agricultural sites in eastern Pennsylvania, USA. Applied Soil Ecology, v. 6, n. 1, p. 35-48, 2001.

GALVEZ, L.; DOUDS, D.D.; DRINKWATER, L.E.; WAGONER, P. Effect of tillage and farming system upon VAM fungus populations and mycorrhizas and nutrient uptake of maize. Plant and Soil, v. 228, n. 2, p. 299-308, 2001. 
GANDARA, F.B.; KAGEYAMA, P.Y. Biodiversidade e dinâmica em sistemas agroflorestais. In. CONGRESSO BRASILEIRO DE SISTEMAS AGROFlorEStAIS, 3., Manaus, 2000. Palestras. Manaus: Embrapa Amazônia Ocidental, 2001. p. 25-33.

GERDEMANN, J.W.; NICOLSON, T.H. Spores of mycorrhizal Endogone species extracted from soil by wet sieving and decanting. Transactions of the British Mycological Society, v. 46, n. 2, p. 235-44, 1963.

GIOVANNETTI, M.; MOSSE, B. Evaluation of techniques for measuring vesiculararbuscular mycorrhizal infection in roots. New Phytologist, v. 84, n. 3, p. 482-500, 1980.

HAAG, D. Root distribution patterns in a polycultural systems with local tree crops on a acid upland soil in central Amazonia. Bayreuth, 1997. 86p. Diplomarbeit, University of Bayreuth.

HARRISON, M.J. Molecular and cellular aspects of the arbuscular mycorrhizal symbiosis. Annual Review of Plant Physiology and Plant Molecular Biology, v. 50, p. 361-389, 1999.

HEIJDEN, M.G.A.; KLIRONOMOS, J.N.; URSIC, M.; MOUTOGOLIS, P.; STREITWOLF-ENGEL, R.; BOLLER, T.; WIEMKEN, A.; SANDERS, I.R. Mycorrhizal fungal diversity determines plant biodiversity, ecosystem variability and productivity. Nature, v. 6, n. 6706, p. 69-72, 1998.

HELGASON, T.; FITTER, A.H.; YOUNG, J.P.W. Molecular diversity of arbuscular mycorrhizal fungi colonising Hyacinthoides non-scripta (bluebell) in seminatural woodland. Molecular Ecology, v. 8, n. 4, p. 659-666, 1999.

HELGASON, T.; DANIELL, T.; HUSBAND, J.R.; FITTER, A.H.; YOUNG, J.P.W. Ploughing up the wood-wide web?. Nature, v. 394, n. 6692, p. 431, 1998. 
HENDRIX, J.W.; GUO, B.Z.; AN, Z.Q. Divergence of mycorrhizal fungal communities in crop production systems. Plant and Soil, v. 170, n. 1, p. 131-140, 1995.

HOMMA, A.K.O.; CARVALHO, R.A. MENEZES, A.J.E.A. Extrativismo e plantio racional de cupuaçuzeiros no sudeste paraense: a transição inevitável (compact disc). In. CONGRESSO BRASILEIRO DE ECONOMIA E SOCIOLOGIA RURAL, 39., Recife, 2001. Anais. Brasília: SOBER, 2001.

HUANG, X.; MADAN, A. CAP3: a DNA sequence assembly program. Genome Research, v. 9, n .9, p. 868-877, 1999.

HUSBAND, R.; HERRE, E.A; TURNER, S.L.; GALLERY, R.; YOUNG, J.P.W. Molecular diversity of arbuscular mycorrhizal fungi and patterns of host association over time and space in a tropical forest. Molecular Ecology , v. 11, n. 12, p. 2669$2678,2002$.

International culture colletion of (vesicular) arbuscular mycorrhizal fungi. $<$ http://invam.caf.wvu.edu> (30 maio 2004).

JACQUOT, E.; TUINEN, D.; GIANINAZZI, S.; GIANINAZZI-PEARSON, V. Monitoring species of arbuscular mycorrhizal fungi in planta and in soil by neste PCR: application to the study of the impact of sewage sludge. Plant and Soil, v. 226, n. 2, p. 179-188, 2000.

JANOS, D.P. Vesicular-arbuscular mycorrhizae affect the growth of Bactris gasipaes H.B.K. Principes, v. 21, n. 1, p.12-18, 1977.

JENKINS, W.R. A rapid centrifugation technique for separating nematodes from soil. Plant Disease Reporter, v. 48, p. 692, 1964. 
JOHNSON, D.; VANDENKOORNHUYSE, P. J.; LEAKE, J. R.; GILBERT, L.; BOOTH, R. E.; GRIME, J. P.; YOUNG, J. P. W.; READ, D. J. Plant communities affect arbuscular mycorrhizal fungal diversity and community composition in grassland microcosms. New Phytologist, v. 161, n. 2, p. 503-515, 2004.

JOHNSON, N.C.; PFLEGER, F.L. Vesicular-arbuscular mycorrhizae and cultural stresses. In. BETHLENFALVAY, G. J.; LINDERMAN, R.G. (Ed.). Mycorhhizae in sustainable agriculture. Madison: ASA, 1992. p. 71-99.

JOHNSON, N.C.; WEDIN, D.A. Soil carbon, nutrients, and mycorrhizae during conversion of dry tropical forest to grassland. Ecological Applications, v. 7, n. 1, p. 171-182, 1997.

JOHNSON, N.C. ; COPELAND, P.J. ; CROOKSTON, R.K.; PFLEGER, F.L. Mycorrhizae: possible explanation for yield decline with continuous corn and soybean. Agronomy Journal, v. 84, n. 3, p. 387-390, 1992.

KABIR, Z.; OHALLORAN, I.P.; FYLES, J.W.; HAMEL, C. Seasonal changes of arbuscular mycorrhizal fungi as affected by tillage practices and fertilization: Hyphal density and mycorrhizal root colonization. Plant and Soil, v. 192, n. 2, p. 285-293, 1997

KENNEDY, A.C.; SMITH, K.L. Soil microbial diversity and the sustainability of agricultural soils. Plant and Soil, v. 170, p. 75-86, 1995.

KJOLLER, R.; ROSENDAHL, S. Detection of arbuscular mycorrhizal fungi (Glomales) in roots by nested PCR and SSCP (Single Stranded Conformation Polymorphism). Plant and Soil , v. 226, n. 2, p. 189-196, 2000.

KJOLLER, R.; ROSENDAHL, S. Molecular diversity of glomalean (arbuscular mycorrhizal) fungi determined as distinct Glomus specific DNA sequences from roots of field grown peas. Mycological Research, v.105, n.9 , p. 1027-1032, 2001. 
KLIRONOMOS, J.N.; McCUNE, J.; HART, M.; NEVILLE, J. The influence of arbuscular mycorrhization on the relationship between plant diversity and productivity . Ecology Letters, v. 3, n. 2, p. 137-141, 2000.

KOCH, A.M.; KUHN, G.; FONTANILLAS, P.; FUMAGALLI, L.; GOUDET, I.; SANDERS, I.R. High genetic variability and low local diversity in a population of arbuscular mycorrhizal fungi. Proceedings of the National Academy of Sciences of the United States of America, v. 101, n. 8, p. 2369-2374, 2004.

KOWALCHUK, G.A.; SOUZA, F.A.; VAN VEEN, J.A. Community analysis of arbuscular mycorrhizal fungi associated with Ammophila arenaria in Dutch coastal sand dunes. Molecular Ecology, v. 11, n. 3, p. 571-581, 2002.

KUHN, G.; HIJRI, M.; SANDERS, I. R. Evidence for the evolution of multiple genomes in arbuscular mycorrhizal fungi. Nature, v. 414, n. 6865, p. 745-748, 2001.

LAMBAIS, M.R.; CARDOSO, E.J.B.N. Avaliação da germinação de esporos de fungos micorrízicos vesículo-arbusculares e da colonização micorrízica de Stilosanthes guianensis em solo ácido e distrófico. Revista Brasileira de Ciência do Solo, v.13, n.2, p.151-154, 1988.

LANFRANCO, L.; DELPERO, M.; BONFANTE, P. Intrasporal variability of ribosomal sequences in the endomycorrhizal fungus Gigaspora margarita. Molecular Ecology, v. 8, n.1, p. 37-45, 1999.

LANFRANCO, L.; BIANCIOTTO, V.; LUMINI, E.; SOUZA, M.; MORTON, J.B.; BONFANTE, P. A combined morphological and molecular approach to characterize isolates of arbuscular mycorrhizal fungi in Gigaspora (Glomales). New Phytologist, v. 152, n. 1, p. 169-179, 2001. 
LLOYD-MACGILP, S.A. ; CHAMBERS, S.M. ; DODD, J.; FITTER, A.H.; WALKER, C.; YOUNG, J.P.W. Divesrity of the ribosomal internal transcribed spacers within and among isolates of Glomus mosseae and related mycorrhizal fungi. New Phytologist, v. 133, n. 1, p.103-111, 1996.

LOCATELLI, M.; SOUZA, V.F. ; VIEIRA, A.H.; QUISEN, R.C. Nutrientes e biomassa em sistemas agroflorestais com ênfase no cupuaçuzeiro, em solo de baixa fertilidade. Porto Velho: Embrapa Rondônia, 2001. 17 p. (Embrapa Rondônia. Boletim de Pesquisa e Desenvolvimento, 1).

LOPES, E.S.; OLIVEIRA, E.; DIAS, R.; SCHENK, N.C. Occurrence and distribution of vesicular-arbuscular mycorrhizal fungi in coffee (Coffea arabica L.) plantations in central São Paulo state, Brazil. Turrialba, v. 33, n. 4, p. 417-422, 1983.

MAGURRAN, A. E. Ecological diversity and its measurement. Princeton: Princeton University Press, 1988. 179p.

MASON, P. A.; MUSOKO, M.O.; LAST, F.T. Short-term changes in vesiculararbuscular mycorrhizal spore populations in Terminalia plantations in Camaeroon. In. READ, D.J.; LEWIS, D.H. FITTER, A.H. Mycorrhizas in ecosystems. Wallingford: Cabi, $1994 . \quad$ p. 261-267.

MERRYWEATHER, J.; FITTER, A. The arbuscular mycorrhizal fungi of Hyacnithoides non-scripta I. Diversity of fungal taxa. New Phytologist, v. 138, n. 1, p. 117-129, 1998.

MILLER, R. L.; JACKSON, L. E. Survey of vesicular-arbuscular mycorrhizae in lettuce production in relation to management and soil factors. Journal of Agricultural Science, v. 130, p. 173-182, 1998. 
MORAES, C. R. A. Radiação solar, desenvolvimento e produção de palmitos de pupunha (Bactris gasipaes H.B.K.) em sistemas agroflorestais na Amazônia Ocidental. Piracicaba, 2002. 86p. Tese (Doutorado) - Escola Superior de Agricultura “Luiz de Queiroz”. Universidade de São Paulo.

MORA-URPI, J.; WEBER, J.C.; CLEMENT, C.R. Peach palm. Bactris gasipaes Kunth. Rome: Institute of Plant Genetics and Crop Plant Research/International Plant Genetic Resources Institute. 1997. 83p. (Promoting the Conservation and Use of Underutilized and Neglected Crops, 20).

MOREIRA, F.M.S. ; SIQUEIRA, J.O. Microbiologia e bioquímica de solo. Lavras: UFLA, 2002. 626p.

MOREIRA-SOUZA, M.; TRUFEM, S.F.B.; GOMES-DA-COSTA, S.M.; CARDOSO, E.J.B.N. Arbuscular mycorrhizal fungi associated with Araucaria angustifolia (Bert.) O. Ktze. Mycorrhiza, v. 13, n. 4, p. 211-215, 2003.

MORTON, J.B. Evolutionary relationships among arbuscular mycorrhizal fungi in the endogonaceae. Mycologia, v. 82, n. 2, p. 192-207. 1990.

MORTON, J.B.; BENNY, G.L. Revised classification of arbuscular mycorrhizal fungi (Zygomycetes ; New order, Glomales, two new suborders, Glominae and Gigasporinae, and two new families, Acaulosporaceae and Gigasporaceae, with an emendation of Glomaceae). Mycotaxon, v. 37, n. 1, p. 471-491, 1990.

MORTON, J.B.; REDECKER, D. Two new families of Glomales, Archaeosporaceae and Paraglomaceae, with two new genera Archaeospora and Paraglomus, based on concordant molecular and morphological characters. Mycologia, v. 93, n.1, p. 181$195,2001$.

MORTON, J.B.; BENTIVENGA, S.P.; BEVER, J.D. Discovery, Measurement, and Interpretation of Diversity in Arbuscular Endomycorrhizal Fungi (Glomales, Zygomycetes). Canadian Journal of Botany, v. 73, p. S25-S32, 1995. 
MUNKVOLD, L.; KJOLLER, R.; VESTBERG, M.; ROSENDAHL, S.; JAKOBSEN, I. High functional diversity within species of arbuscular mycorrhizal fungi. New Phytologist, v. 164, n. 2, p. 357-364, 2004.

NAIR, P.K.R. An introduction to agroforestry. Boston: Kluwer Academic, 1993. 499p.

ODUM, E.P. Ecologia. Rio de Janeiro: Guanabara, 1988. 434p.

OLIVEIRA, A.N.; OLIVEIRA, L.A. Colonizações micorrízicas em sistema agroflorestal com cupuaçu e guaraná em um Latossolo ácido e de baixa fertilidade da Amazônia Central. In: CONGRESSO BRASILEIRO DE SISTEMAS AGROFLORESTAIS, 3., Manaus, 2000. Resumos expandidos. Manaus: Embrapa Amazônia Ocidental, 2000. p. $94-96$

OLIVEIRA, A.N.; OLIVEIRA, L.A.; OLIVEIRA, F.W. Micorrizas arbusculares em cupuaçu e guaraná de um sistema agroflorestal de terra firme no município de Manaus. In. RENUNIÃO DE FERTILIDADE DO SOLO E NUTRIÇÃO DE PLANTAS, 23., REUNIÃO BRASILEIRA SOBRE MICORRIZAS, 7., SIMPOSIO BRASILEIRO DE MICROBIOLOGIA DO SOLO, 5., REUNIÃO BRASILEIRA DE BIOLOGIA DO SOLO, 2., Caxambu, 1998. Resumos, Lavras: UFLA;SBCS;SBM，1998. p. 617.

OPIK, M.; MOORA, M.; LIIRA, J.; KOLJALG, U.; ZOBEL, M.; SEN, R. Divergent arbuscular mycorrhizal fungal communities colonize roots of Pulsatilla spp. in boreal Scots pine forest and grassland soils. New Phytologist, v. 160, n. 3, p. 581593, 2003.

PAGE, R. D. M. TreeView - version 1.6.6. Glasgow: University of Glasgow, 2001.

PICONE, C. Diversity and abundance of arbuscular-mycorrhizal fungus spores in tropical forest and pasture. Biotropica, v. 32, n. 4, p. 734-750, 2000. 
PINTO-COELHO, R.M. Fundamentos em ecologia. Porto Alegre: Artmed Editora, 2000. 252 p.

REDECKER, D. Specific PCR primers to identify arbuscular mycorrhizal fungi within colonized roots. Mycorrhiza, v. 10, n. 2, p. 73-78, 2000.

REISDORFF, C., GASPAROTTO, L.; LIEBEREI, R. Development and production of cupuaçu plants (Theobroma grandiflorum) on degraded areas: implications of water relations. In. LIEBEREI, R.; BIANCHI, H. K.; BOEHM, V.; REISDORFF, C. (Ed.). Neotropical ecosystems. Geesthacht: GKSS . 2002. p. 661-668.

RENKER, C.; HEINRICHS, J.; KALDORF, M.; BUSCOT, F. Combining nested PCR and restriction digest of the internal transcribed spacer region to characterize arbuscular mycorrhizal fungi on roots from the field. Mycorrhiza, v. 13, n. 4, p. 191-198, 2003.

RICKLEFS, R.E. Ecology. New York: W.H. Freeman, 1990. 896p.

RODRIGUES, T.E.; REIS, R.S. dos; MORIKAWA, I.K.; FALESI, I.C.; SILVA, B.N.R. de; GUIMARÃES, G.A.; LOPES, E.C.; BASTOS, J.B. Levantamento detalhado dos solos do IPEAAOc. Manaus: IPEAAOc, 1972. 63p. (IPEAAOc. Boletim Técnico, 1).

RODRIGUEZ, A.; DOUGALL, T.; DODD, J. C.; CLAPP, J. P. The large subunit ribosomal RNA genes of Entrophospora infrequens comprise sequences related to two different glomalean families. New Phytologist, v. 152, n. 1, p. 159-167, 2001.

RUIZ, P.O. El rol de la micorrizas en pijuayo (Bactris gasipaes HBK). In: CONGRESSO INTERNACIONAL SOBRE BIOLOGIA, AGRONOMIA E INDUTRIALIZACION DEL PIJUAYO, 4., Iquitos, 1991. Congresso. Iquitos: Editorial de la Universidad de Costa Rica, 1993. p.127-134. 
SAGGIN JR., O.; SIQUEIRA, J.O. Micorrizas arbusculares em cafeeiro. In SIQUEIRA, J. O. Avanços em fundamentos e aplicação de micorrizas. Lavras:UFLA, 1996. p.203-254.

SAIF, S.R. Vesicular-arbuscular mycorrhizae in tropical forage species as influenced by season, soil texture, fertilizers, host species and ecotypes. Angewandte Botanik, v. 60 , n. $1 / 2$, p. $125-139,1986$.

SAMBROOK, J. ; FRITSCH, E. F. ; MANIATIS, T. Molecular cloning: a laboratory manual. 2.ed. Cold Harbor: Cold Spring Harbor Laboratory Press, 1989.

SANCHES, P. Suelos del tropico: características y manejo. San Jose: IICA, 1981. 660 p.

SANDERS, I.R.; ALT, M.; GROPPE, K.; BOLLER, T.; WIEMKEN, A. Identification of ribosomal DNA polymorphisms among and within spores of the Glomales: application to studies on the genetic diversity of arbuscular mycorrhizal communities. New Phytologist, v. 130, n. 3, p. 419-427, 1995.

SCHENCK, N.C.; PEREZ, Y. Manual for the identification of VA mycorrhizal fungi. 2.ed. Gainsville: University of Florida, 1987. 242p.

SCHROTH, G.; SILVA, L.F.; WOLF, M.A.; TEIXEIRA, W.G.; ZECH, W. Distribution of throughfall and stemflow in multi-strata agroforestry, perennial monoculture, fallow and primary forest in central Amazonia, Brazil. Hydrological Processes, v. 13, n. 10, p.1423-1436, 1999.

SCHROTH, G.; TEIXEIRA, W.G.; SEIXAS, R.; SILVA, L.F.; SCHALLER, M.; MACEDO, J.L.V.; ZECH, W. Effect of five tree crops and a cover crop in multistrata agroforestry at two fertilization levels on soil fertility and soil solution chemistry in central Amazonia. Plant and Soil, v. 221, n. 2, p. 143-156, 2000. 
SCHWARZOTT, D.; WALKER, C.; SCHUSSLER, A. Glomus, the largest genus of the arbuscular mycorrhizal fungi (Glomales), is non monophyletic. Molecular Phylogenetics and Evolution, v. 21, n. 2, p. 190-197, 2001.

SCHWEIGER, P. F.; JAKOBSEN, I. Direct measurement of arbuscular mycorrhizal phosphorus uptake into field-grown winter wheat. Agronomy Journal, v. 91, n. 6, p. 998-1002, 1999.

SIEVERDING, E. Vesicular-arbuscular mycorrhiza management in tropical agrosystems. Eschborn: GTZ, 1991.371p.

SILVA, E.M.R.; SUDO, A.; ALMEIDA, D.L. de; MATOS, R.M.B.; PEREIRA, M.G.; BOVI, M.L.A.; MACHADO, C.T.T. Ocorrência e efetividade de fungos micorrízicos arbusculares em espécies cultivadas. Seropédica: EMBRAPACNPAB, 1998. 16 p. (EMBRAPA CNPAB. Documentos, 83).

SILVA, F.C. (Org.). Manual de análises químicas de solos, plantas e fertilizantes. Brasília: Embrapa Comunicação para Transferência de Tecnologia, 1999. 370p.

SILVA, M.L.N. Erosividade da chuva e proposição de modelos para estimar a erodibilidade de latossolos brasileiros. Lavras, 1997. 154p. Tese (Doutorado) Universidade Federal de Lavras.

SILVEIRA, A.P.D. Ecologia de fungos micorrízicos arbusculares. In. MELO, I.S.M.; AZEVEDO, J.L. (Ed.). Ecologia microbiana. Jaguariúna: Embrapa CNPMA, 1998. p. $61-86$

SIMON, L. Phylogeny of the glomales: deciphering the past to understand the present. New Phytologist, v. 133, n.1, p. 95-101, 1996.

SIMON, L.; LALONDE, M.; BRUNS, T.D. Specific amplification of $18 \mathrm{~S}$ fungal ribosomal genes from vesicular-arbuscular endomycorrhizal fungi colonizing roots. Applied and Environmental Microbiology, v. 58, n. 1, p. 291-295, 1992. 
SIMON, L.; BOUSQUET, J.; LÉVESQUE, R.C.; LALONDE, M. Origin and diversity of endomycorrhizal and coincidence with vascular land plants. Nature, v. 363, n. 6424, p. 67-69, 1993.

SIQUEIRA, J.O.; KLAUBERG-FILHO, O. Micorrizas arbusculares: a pesquisa brasileira em perspectiva. In. NOVAIS, R.; ALVAREZ, V.H. ; SCHAEFFER, C.E. Tópicos em Ciência do Solo. Viçosa: Sociedade Brasileira de Ciência do Solo, 2000. p. 235-264

SMITH, F.A.;SMITH, S.E. Structural diversity in (vesicular)-arbuscular mycorrhizal symbioses. New Phytologist, v. 137, n. 3, p. 373-388, 1997.

SMITH, S.E.; READ, D.J. Mycorrhizal symbiosis. San Diego: Academic Press, 1997. $605 \mathrm{p}$.

SOUZA, A.G.C.; SOUSA, N.R. ; SILVA, S.E.L.; NUNES, C.D.M.; CANTO, A.C.; CRUZ, L.A.A. Fruteiras da Amazônia. Brasilia: Embrapa-SPI; Manaus:Embrapa CPAA, 1996. 204p.

SOUZA, M.M.S.R. Ecofisiologia de fungos micorrízicos arbusculares em Araucaria angustifolia. Piracicaba, 2000. 108p. Tese (Doutorado) - Escola Superior de Agricultura "Luiz de Queiroz". Universidade de São Paulo.

THOMPSON, J.P. Decline of vesicular-arbuscular mycorrhizae in long fallow disorder of field crops and its expression in phosphorus deficiency of sunflower. Australian Journal of Agricultural Research, v. 38, n. 5, p. 847-867, 1987.

THOMPSON, J.D.; GIBSON, T.J.; PLEWNIAK, F.; JEANMOUGIN, F.; HIGGINS, D.G.; The ClustalX windows interface: flexible strategies for multiple sequence alignment aided by quality analysis tools. Nucleic Acids Research, v. 24, p. 8764882, 1997. 
UGUEN, K.; BERNHARD-REVERSAT, F.; LUIZÃO, F.; SILVA, J.P.; SCHROTH, G. Nutrient fluxes from litter and prunings in an agroforestry system in central Amazonia. In. LIEBEREI, R.; BIANCHI, H.K.; BOEHM, V.; REISDORFF, C. (Ed.). Neotropical ecosystems. Geesthacht: GKSS, . 2002. p. 851-853.

VALENTIN, J.L. Ecologia numérica. uma introdução à análise multivariada de dados ecológicos. Rio de Janeiro: Interciências, 2000. 117 p.

VANDENKOORNHUYSE, P.; LEYVAL, C. SSU rDNA sequencing and PCRfingerprinting reveal genetic variation within Glomus mossea. Mycologia, v. 90, n. 5, p. 791-797, 1999.

VANDENKOORNHUYSE, P.; HUSBAND, R.; DANIELL, T.J.; WATSON, I. J.; DUCK, J.M.; FITTER, A. H.; YOUNG, J.P.W. Arbuscular mycorrhizal community composition associated with two plant species in a grassland ecosystem. Molecular Ecology, v. 11, n. 8, p. 1555-1564, 2002.

VANDERMEER, J. Observations on the root system of the pejibaye palm (Bactris gasipaes H.B.K.) in Costa Rica. Turrialba, v. 27, n. 3, p. 239-242, 1977.

VIERA, A.; GLENN, M.G. DNA content of vesicular-arbuscular mycorrhizal fungal spores. Mycologia , v. 82, n. 2, p. 263-267, 1990.

VIERHEILIG, H.; GOUGHLAN, A.P.; WYSS, U.; PICHÉ, Y. Ink and vinegar, a simple staining technique for arbuscular-mycorrhizal fungi. Applied Environnmental Microbiology, v. 64, n.12, p. 5004-5007, 1998.

WANDELLI, E.V.; SOUZA, M.P.S. Análise da sustentabilidade de sistemas agroflorestais do Estado do Amazonas através da diversidade florística. In: CONGRESSO BRASILEIRO DE SISTEMAS AGROFLORESTAIS, 3., Manaus, 2000. Resumos expandidos. Manaus: Embrapa Amazônia Ocidental, 2000. p. 2628. 
WILSON, J.; INGLEBY, K.; MASON , P.A.; IBRAHIM, K.; LAWSON, G.J. Longterm changes in vesicular-arbuscular mycorrhizal spore populations in Terminalia plantations in Côte d'Ivoire. In . READ, D.J.; LEWIS, D.H. FITTER, A.H. Mycorrhizas in ecosystems. Wallingford: Cabi, 1994. p. 268-275.

WYSS, P.; BONFANTE, P. Amplification of genomic DNA of arbuscular mycorrhizal (AM) fungi by PCR using short arbitrary primers. Mycological Research, v. 97, p. 1351-1357, 1993.

ZHAO, Z.W.; XIA, Y.M.; QIN, X.Z.; LI, X.W.; CHENG, L.Z.; SHA, T.; WANG, G.H. Arbuscular mycorrhizal status of plants and the spore density of arbuscular mycorrhizal fungi in the tropical rain forest of Xishuangbanna, southwest China. Mycorrhiza, v. 11, n. 3, p. 159-162, 2001. 